LBL-8405

$\mathrm{UC}-59 \mathrm{c}$ c.2

\section{TWO-WEEK LOAN COPY}

This is a Library Circulating Copy which may be borrowed for two weeks. For a personal retention copy, call Tech. Info. Division, Ext. 6782
ReO 190

I Awronce

BETLIP LABOARON

JAN 291979

I.IBHARY AND

MOMMENTS SHCTON

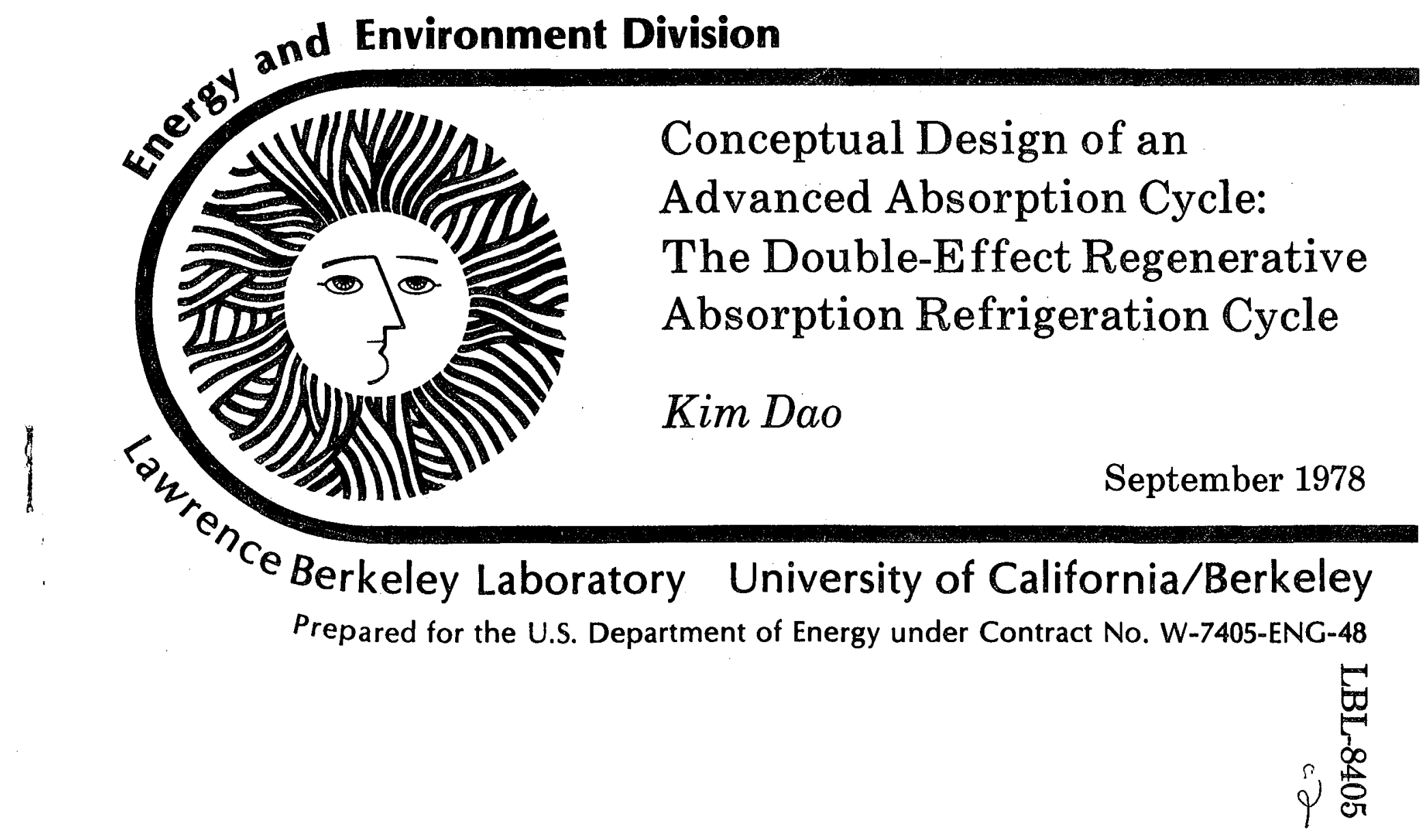




\section{LEGAL NOTICE}

This report was prepared as an account of work sponsored by the United States Government. Neither the United States nor the Department of Energy, nor any of their employees, nor any of their contractors, subcontractors, or their employees, makes any warranty, express or implied, or assumes any legal liability or responsibility for the accuracy, completeness or usefulness of any information, apparatus, product or process disclosed, or represents that its use would not infringe privately owned rights.

Printed in the United States of America

Available from

National Technical Information Service

U. S. Department of Commerce

5285 Port Royal Road

Springfield, VA 22161

Price: Printed Copy, \$ 5.25 Domestic; $\$ 10.50$ Foreign

Microfiche, \$3.00 Domestic; \$4.50 Foreign 


\title{
CONCEPTUAL DESIGN OF AN ADVANCED ABSORPTION CYCLE: THE DOUBLE-EFFECT REGENERATIVE ABSORPTION REFRIGERATION CYCLE
}

Kim Dao

\begin{abstract}
Lawrence Berkeley Laboratory University of California Berkeley, California, 94720
\end{abstract}

September 1978

This work has been supported by the Solar Heating and Cooling Research and Development Branch, Office of Conservation and Solax Application, U.S. Department of Energy. 


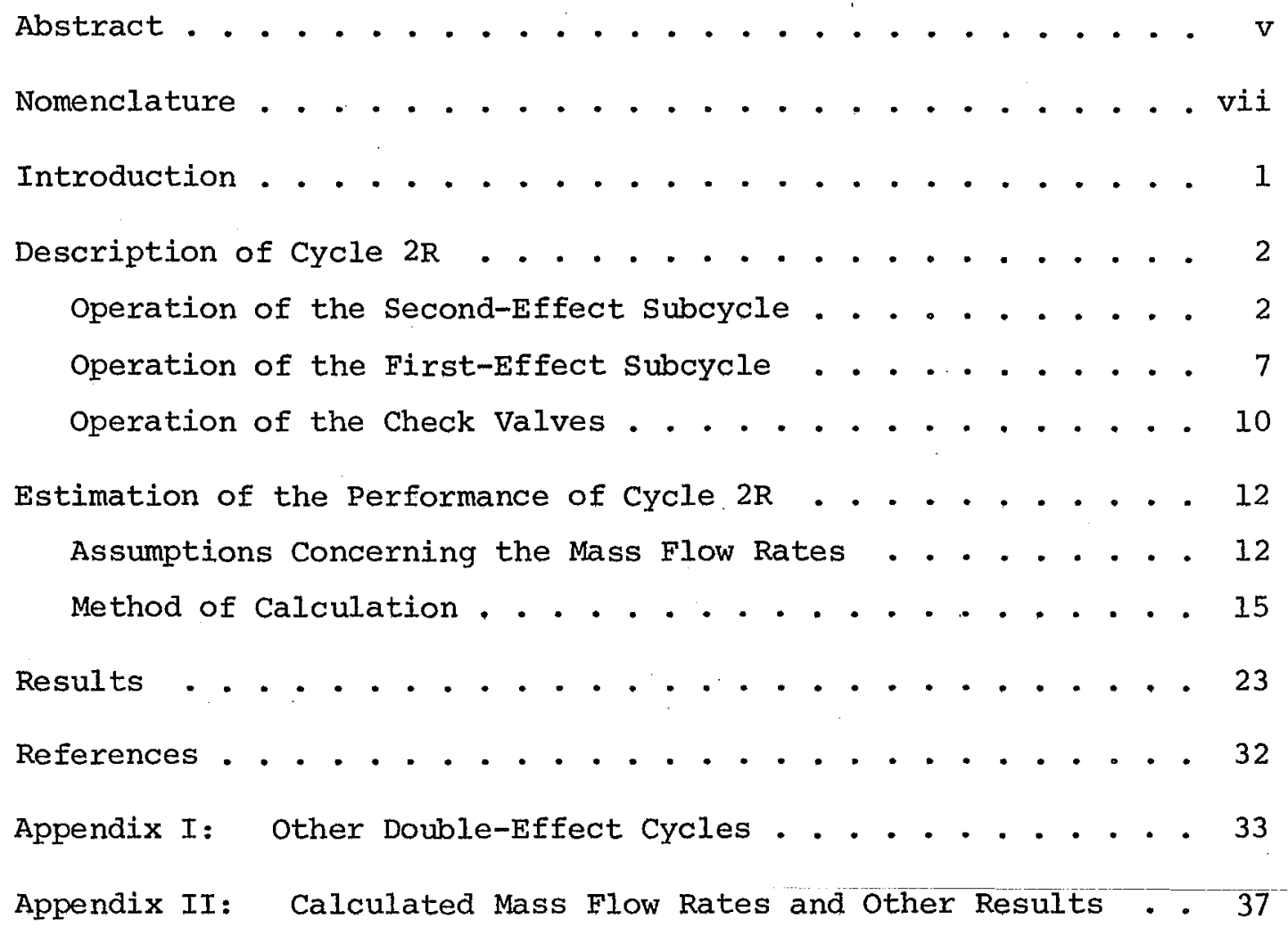


ABSTRACT

An advanced absorption refrigeration cycle was proposed as a heatactivated refrigeration system. Referred to as the double-effect regenerative absorption cycle or cycle $2 \mathrm{R}$, it improves the performance of the conventional single-effect absorption cycle at high heat source temperatures. The performance of cycle $2 \mathrm{R}$ continually improves as input temperatures rise, in contrast to the conventional double-effect absorption cycle that has a sharp cut-off temperature below which it ceases to operate. Cycle 2R operates with two subcycles, the firsteffect and the second-effect subcycles. The second-effect subcycle is a conventional single-effect cycle activated by heat rejected from the first-effect subcycle. The first-effect subcycle is a new absorption cycle operating with a multi-pressure-stage boiling process (boiler) driven by the heat source in such a way that the boiling process occurs essentially at constant temperature. A regeneration process between the first-effect boiler and the second-effect generator makes possible the recovery of heat that otherwise would be lost, thus improving the efficiency of the system.

The advantages of cycle $2 \mathrm{R}$ over the conventional cycles are:

- A continuously higher practical coefficient of performance (COP) at increasing input temperatures, following the Carnot COP trend (about 63\%).

- A much lower practical cut-off input temperature. Practically, cycle $2 \mathrm{R}$ works at any heat source temperature about $40^{\circ} \mathrm{F}$ higher than the condensing temperature. Theoretically, cycle $2 \mathrm{R}$ has no cut-off temperature. 

NOMENCLATURE

$z$ : mass flow rates relative to the mass flow rate of line 2 (Fig. 3)

$r$ : return ratio defined as:

$r=\frac{\text { (mass flow rate from station } 10 \text { to station } 11 \text { ) }}{\text { (total mass flow rate at station 10) }}$. See Fig. 1 or 2 .

$s$ : fraction of the total mass flow rate from station 1 to station 2

diverted to station 7 (Fig. 1 or 2 )

$T$ : temperature, ${ }^{\circ} \mathrm{F}$

$x$ : concentration, weight fraction of refrigerant in mixture (either vapor or solution)

p : pressure, psia

$h$ : enthalpy, Btu/lb

$G$ : generator

C : condenser

$\mathbf{E}$ : evaporator

$\mathrm{R}$ : recuperator

B : boiler

0 : condenser-absorber

Terms used in computer print-outs:

$\mathrm{DT}=\mathrm{T}_{4}-\mathrm{T}_{3}$ (See Fig. 3)

Max. Recoverable Heat in Preheater: Total heat obtained when $z_{3}, z_{4}$, $\mathrm{z}_{14}, \mathrm{z}_{15}$ and $\mathrm{z}_{16}$ are cooled to $\mathrm{T}_{0}$ in the preheater. 



\section{INTRODUCTION}

The double-effect regenerative absorption refrigeration cycle (or cycle 2R) is an effort by the Lawrence Berkeley Laboratory to design an efficient cooling system for solar applications. Present solaractivated cooling systems have either a low efficiency or a sharp cutoff temperature that prevents the effective use of highly variable solar radiation. Conventional single-effect absorption systems have a low coefficient of performance (COP) of the order of 0.70 and a sharp cut-off input temperature of about $200^{\circ} \mathrm{F}$. Conventional doubleeffect absorption systems have a good COP of about 1.10 but unfortunately, they also have a sharp cut-off input temperature of about $300^{\circ} \mathrm{F}$. This high cut-off temperature may render the system inoperative (or operative with very low collector efficiencies) during a considerable period when solar radiation is low. Rankine-vapor compression systems have no cutoff input temperatures but their COP's are likely limited to less than $50 \%$ of the Carnot COP.

The cycle $2 \mathrm{R}$ described in this report has a continuously increasing COP at higher temperatures, approaching 63\% of the Carnot COP. This cycle works efficiently with input temperatures from $160^{\circ} \mathrm{F}$ to about $300^{\circ} \mathrm{F}$ (the condenser and the evaporator temperatures being $110^{\circ} \mathrm{F}$ and $40^{\circ} \mathrm{F}$, respectively). 
DESCRIPTION OF CYCLE 2R

The operation of cycle $2 \mathrm{R}$ is described below and numerically traced in Figure 1 (thermodynamic cycle) and Figure 2 (schematic of the conceptual design of the system). Note that in Figure 1 the boiling process, station 7 to station 8 , is represented by eight essentially constant pressure boiling stages whereas in Figure 2 that same process is represented by only three boiling stages. Correspondingly, for the resorption process from station 9 to station 3 there are nine essentially constant pressure resorption stages in Figure 1 and only four in Figure 2. The correspondence between Figure 1 and Figure 2 is complete if:

- the midale boiling (zig-zag) coil of the boiler in Figure 2 is visualized as repeating itself six times.

- the resorption (zig-zag) coil and pump-stage $i$ of the generator in Figure 2 are visualized as repeating themselves six times.

Cycle 2R consists of two subcycles, numerically traced in Figures 1 and 2: the second-effect subcycle (stations 1-2-3-4-5-6), and the first-effect subcycle (stations 2-7-12-11-8-9-10-13-3). OPERATION OF THE SECOND-EFFECT SUBCYCLE

The second-effect subcycle is a conventional single-effect absorption cycle that incorporates the high pressure (HP) vapor line within the solution preheater (Fig。2) so that more heat recuperation is possible. Rectification of the HP vapor in the preheater produces a condensate that is extracted about halfway through the preheater. In the second-effect subcycle the strong solution (rich in refrigerant) 


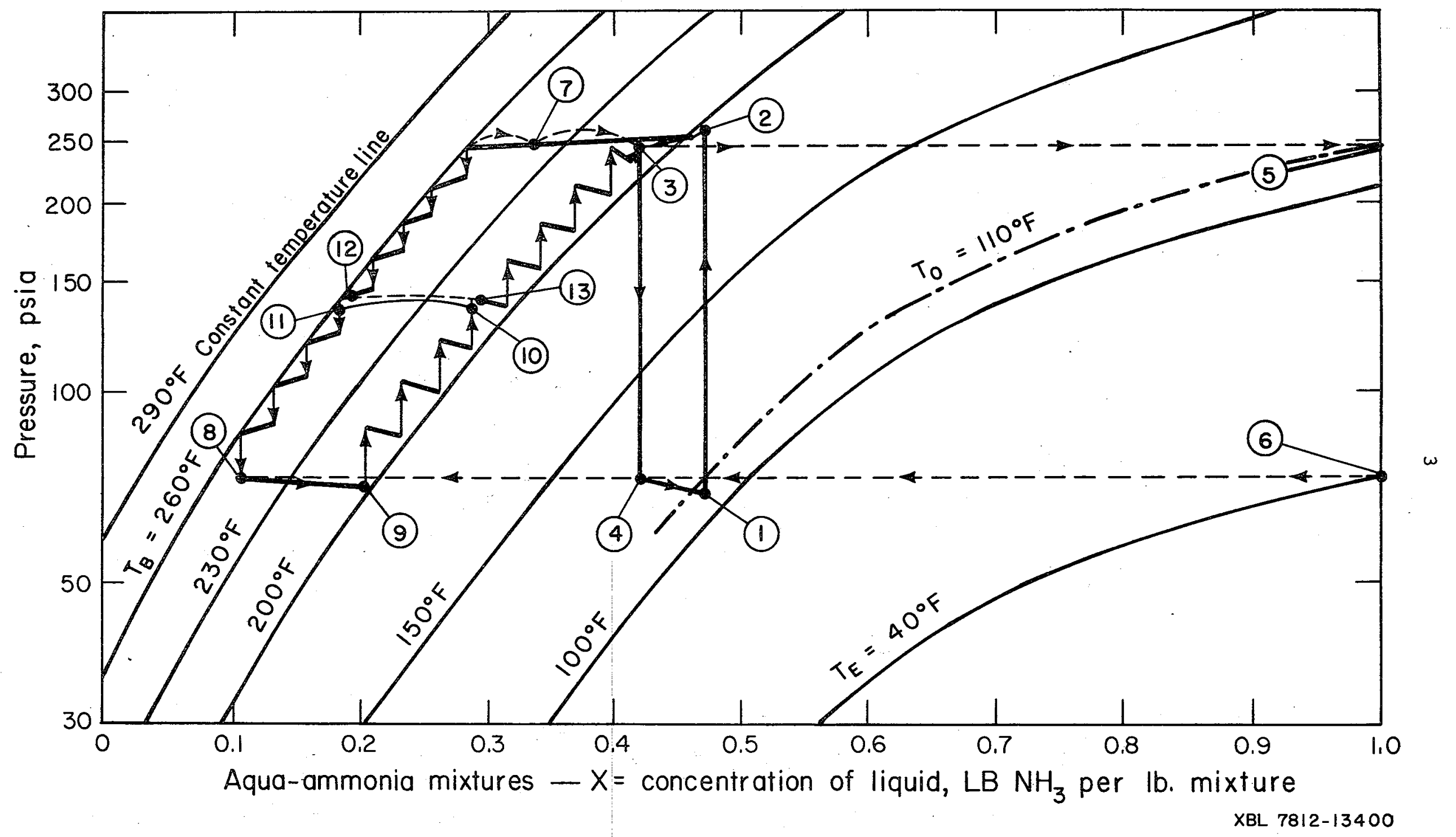

Figure 1. Thermodynamic diagram of cycle $2 R$. 


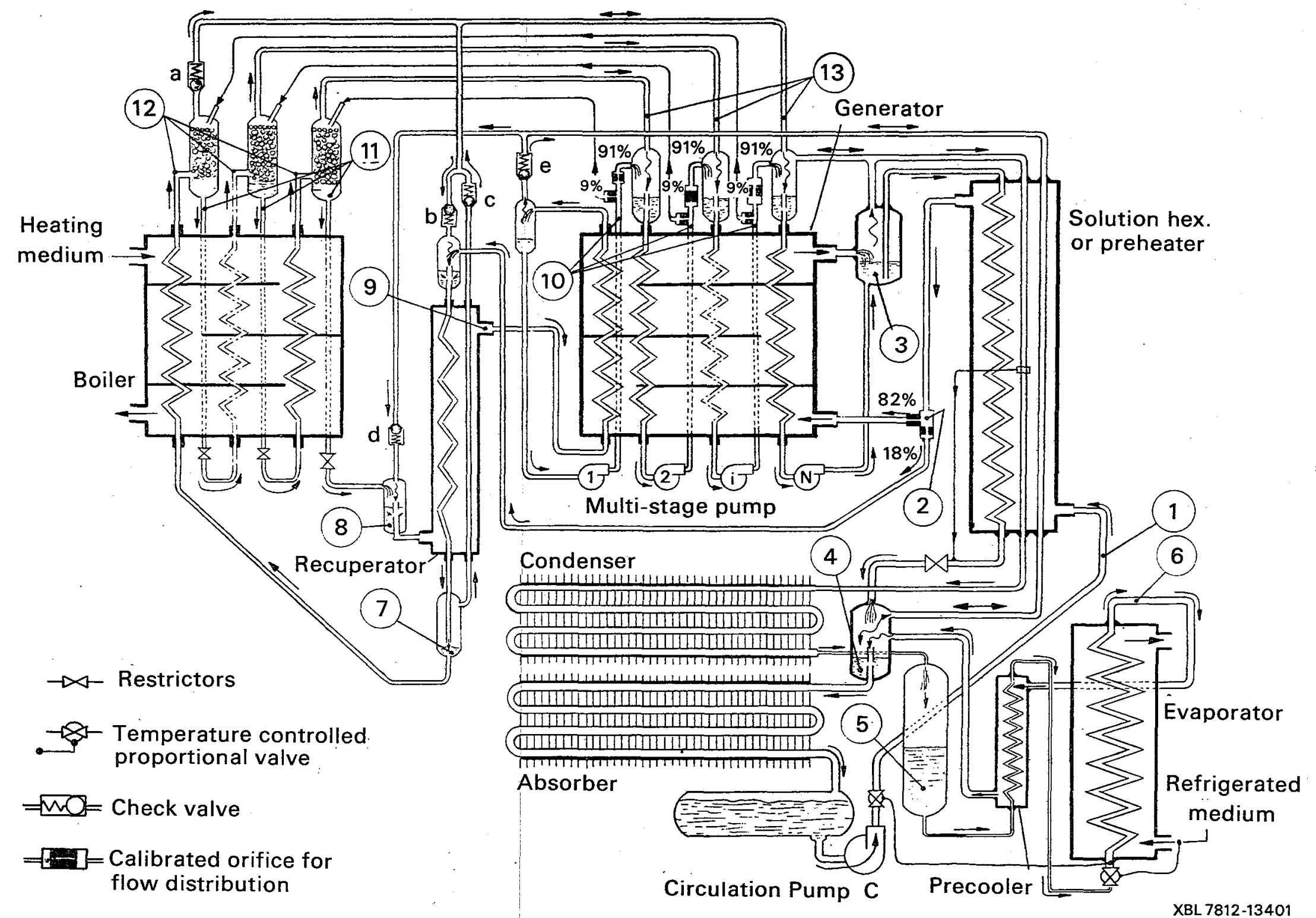

Figure 2. Conceptual design of cycle $2 \mathrm{R}$ refrigeration systems. 
at station 1 is circulated by pump $C$ from the evaporator pressure through the preheater to station 2 at a pressure slightly higher (about 15 psi) than the condenser pressure. At station 2 the mass flow rate of the strong solution is split into two streams by two calibrated orifices. Because the pressure drop across the two orifices is almost equal, the sizes of the orifices determine the relative mass flow rates of the streams. This flow splitting need not be accurate since its influence on the performance of cycle $2 \mathrm{R}$ is small. For the $\mathrm{NH}_{3} / \mathrm{H}_{2} \mathrm{O}$ pair, an allocation of $17 \%$ to $22 \%$ of strong solution diverted to station 7, and $78 \%$ to $83 \%$ to station 3 seems to be a good choice.

The second-effect subcycle continues from station 2 to station 3 through the generator (shell side of the generator). This is a constant pressure generating (or boiling) process heated by the resorption processes from station 9 to station 3 (tube side of the generator). At station 3 , the generating process $2-3$ (shell side) produces a mixture of vapor and weaker solution at condenser pressure. This mixture is separated into its two components which are fed into different lines of the preheater where they exchange heat to the strong solution. The cooled weak solution exciting the preheater at station 4 is expanded through a restrictor to the inlet of the absorber where it starts absorbing the refrigerant vapor coming from the evaporator. The cooled high pressure vapor exiting the preheater is fed into the condenser where it condenses at station 5 and is stored in a tank. The condensed liquid refrigerant is precooled and expanded into the evaporator for the production of refrigeration. The expansion 
valve for the liquid refrigerant is controlled proportionally to the difference in temperatures between the refrigerated medium and a preset value. This valve closes completely at and below the preset temperature. The maximum opening of this expansion valve sets a limit to the maximum cooling capacity of the system.

The circulation outlet, pump $\mathrm{C}$, is also fitted with a temperature (or pressure) controlled proportional valve. When the evaporating temperature (or pressure) rises above a preset value, this valve opens, and conversely it closes when the temperature drops below the preset value. The maximum pumping capacity of pump $C$ is chosen such that there is enough solution to absorb the maximum refrigerant flow to the evaporator under the most unfavorable conditions. For instance, it is capable of a circulation ratio (circulation ratio = strong solution flowrate/refrigerant flow rate) of about 17 for $\mathrm{NH}_{3} / \mathrm{H}_{2} \mathrm{O}$ solutions. Because the system is intended to operate within a given range of temperature conditions, two storage tanks are used to adjust the concentration of the solutions: the refrigerant storage tank at the exit of the condenser and the strong solution storage tank at the exit of the absorber. For example, on a very hot day the absorber temperature can reach $130^{\circ} \mathrm{F}$, if $\mathrm{NH}_{3} / \mathrm{H}_{2} \mathrm{O}$ solutions are used in the system, and the concentration of the strong solution can be 0.41 at pump $C$ (the evaporator temperature being $40^{\circ} \mathrm{F}$ ). On a relatively cooler day, on the other hand, the absorber temperature can be $105^{\circ} \mathrm{F}$, producing a strong solution concentration of 0.49 . The excess $\mathrm{NH}_{3}$ resulting from the concentration change is stored in the refrigerant storage tank. The 
original solution charge must be strong enough for the lowest anticipated absorber temperature and the highest evaporator temperature. Storage tank volume must be calculated according to the anticipated concentration changes and the solution-holding capacity of the system.

To operate cycle $2 \mathrm{R}$ at its maximum, that is, to operate it within a large range of temperature conditions with a COP approaching a high percentage of the Carnot COP, it would be desirable to manage the storage of the heating, cooling and refrigerated media such that the system operates at its highest COP. For example, with a heat source of $270^{\circ} \mathrm{F}$, a heat sink of $75^{\circ} \mathrm{F}$ (night cooling), and a cold storage at $45^{\circ} \mathrm{F}$, the COP of the system can be about 1.4. A possible scheme would be the storage for a heat sink by night cooling, a cold storage, and operation of the cycle $2 \mathrm{R}$ during solar energy collection without a hot storage.

OPERATION OF 'THE FIRST-EFFECT SUBCYCLE:

The first-effect subcycle consists of four main processes:

1. The boiling process (stations 7-12-11-8) in which the solution uses heat from the heat source to generate vapors at many pressure stages such that the whole process occurs at approximately constant temperature. In Figure 1, the boiling process starts at station 7 and continues at constant pressure until the solution reaches its maximum boiling temperature $\left(260^{\circ} \mathrm{F}\right.$ as shown in Fig. 1) compatible with the heat source temperature and with the heat transfer characteristics of the boiler. This segment of the boiling process corresponds to the first (from left) zig-zag coil of the boiler in Figure 2. At the end 
of the coil the solution is separated from the vapor. Since this vapor is at condenser pressure, it is fed to the condenser via the preheater. But before entering the preheater, this vapor is partially rectified by direct contact in a packed pipe with a cooler solution bled from the generator. The 9\% bleeding lines are shown in Figure 2 .

At the end of this first segment of the boiling process, the solution (separated from its vapor) is expanded through a restrictor to a lower pressure stage for further boiling. This boiling process continues throughout the many pressure stages, where the solution boils at constant pressure until it reaches the maximum boiling temperature (e.g., $260^{\circ} \mathrm{F}$ as shown in Figure 1). At the end of each boiling stage, such as at station 12 , the vapor and the solution are separated into two different paths: the solution path which continues the boiling process (that is diverted to station 11 for expansion to a lower pressure boiling stage), and the vapor path to station 13. The vapor path from stations 12 to 13 is part of the solution return process discussed later.

\section{The regeneration process (heat exchange process between line} 2-7 and line 8-9). At the exit of the last boiling stage, the solution (separated from its vapor) is expanded to evaporator pressure. This solution at high temperature and low pressure is very weak. It can absorb vapor boiled off from the evaporator to release a substantial amount of heat at high temperature (1ine 8-9). This heat is absorbed by the boiling strong solution (at condenser pressure) from station 2 to station 7. The vapor generated by the boiling at stations 2 to 7 augments the vapor from the generator (stations 2 to 3 ) for a higher 
system COP. The regeneration process occurs in the recuperator shown in Figure 2. The operation of check valves $a, b, c, d$ and $e$ in Figure 2 will be detailed later.

3. The resorption process (stations 9-10-13-3). At the outlet of the recuperator, station 9, the solution temperature is determined by the heat transfer characteristic of the recuperator. This temperature may not match the temperature of the resorption process, that is, the temperature of the generator. Therefore this solution is fed into the first coil of the generator (from left of Fig. 2) so that further heat exchange can occur for temperature matching.

The resorption process starts at pump stage 1 where the solution coming from station 9 is pumped to the first resorption stage. Each resorption stage occurs at essentially constant pressure across each corresponding zig-zag coil of the generator (Fig. 2). Each pressure stage of the resorption process corresponds to a boiling stage at the same pressure. Each boiling stage produces vapor (such as the vapor flowing from station 12 to station 13) that is absorbed by the solution pumped up from a lower pressure stage (such as at station 10).

The resorption process continues until station 3, where the outlet solution mixes with the weak solution exiting the shell side of the generator (that is, exiting the generating process 2-3).

4. The solution return process (stations 10-11-12-13). The solution return process is the ensemble of flow paths similar to paths 10-11 and 12-13. Each pair of paths, such as 10-11 and 12-13, occurs at constant pressure in a packed segment of pipe where the hot vapor 
produced by each boiling stage exchanges heat and mass (by direct contact) with the solution bled from station 10 . The return ratio is about $8 \%$ to $14 \%$ for $\mathrm{NH}_{3} / \mathrm{H}_{2} \mathrm{O}$ solutions and 8 pressure stages, that is, $8 \%$ to $14 \%$ of the output of each pump stage is returned to the boiler. The remaining $86 \%$ to $92 \%$ of the solution continues the resorption process. The value of the return ratio does not greatly influence the performance of cycle $2 \mathrm{R}$. A good return ratio for $\mathrm{NH}_{3} / \mathrm{H}_{2} \mathrm{O}$ solutions seems to be $10 \% \pm 2 \%$.

\section{OPERATION OF THE CHECK VALVES}

Let $T_{\text {off }}$ be the cut-off temperature of the conventional singleeffect absorption cycle. If cycle $2 \mathrm{R}$ is to be operated only with input temperatures higher than, say, $\mathrm{T}_{\text {off }}+15^{\circ} \mathrm{F}$, then the check valves labeled $a, b, c, d$ and $e$ in Figure 2 are not needed. They are used only to insure the proper flow direction of the vapors when the input temperatures change from higher to lower than $\mathrm{T}_{\text {off }}$.

Operation of cycle 2R with input (boiler) temperature higher than Toff has been described above. In that operating regime, check valve a is opened by the high pressure vapor produced in the first coil of the boiler. The vapor is produced by the solution exiting station 7 which is at a cooler temperature than the boiler, and thus continues to boil in the first coil. The vapor is at a higher pressure than that of the condenser. The same higher pressure closes check valve $b$ and opens $\mathrm{c}$ so that the vapor generated in the recuperator can escape to the condenser. At the same time, the pressure at station 9 is lower than that of the evaporator (because of the cooling and absorption of 
vapor), allowing the evaporator vapor to be fed to the recuperator through valve d. This same lower pressure closes valve e, allowing absorption to continue in the generator from station 9 to the inlet of pump stage 1 .

In operating regimes with input temperatures less than $T_{\text {off }}$ cycle $2 \mathrm{R}$ functions with the same processes described above, except for the following:

1. Solution return process

- Lines 10-11 have the same flow direction but are cooling down instead of heating up.

- Lines 12-13 have the same flow direction but are heating up instead of cooling down.

\section{Regeneration process}

- Line 8-9 has the same flow direction but is boiling and giving off vapor instead of absorbing.

- Line 2-7 has the same flow direction but is absorbing vapor coming from the condenser instead of generating vapor for the condenser. Thus, the regeneration process decreases the vapor output to the condenser and increases the vapor load to the absorber. This reduction of performance is understandable because with a lower input temperature, a lower $C O P$ is expected. Here, the first-effect subcycle of cycle $2 R$ can be considered as a heat pump subcycle that uses the boiler heat input to pump heat from the heat sink to a temperature high enough to run the second-effect subcycle. 
Check valve a is now closed because the temperature at station 7 is higher than that of the boiler; thus, the solution continues to absorb the vapor coming from the condenser in the first coil of the boiler. The pressure in this absorption process is necessarily lower than that of the condenser. Therefore, valve $b$ is opened and valve c is closed. Process $8-9$ is now a boiling process giving off vapor at higher pressure than that of the evaporator. This high pressure closes valve d and opens valve e to allow the produced vapor to escape to the absorber.

ESTIMATION OF THE PERFORMANCE OF CYCLE 2R

Figure 3 and the assumptions listed in Table 1 are used to estimate the COP of cycle $2 \mathrm{R}$ using $\mathrm{NH}_{3} / \mathrm{H}_{2} \mathrm{O}$ solutions. ASSUMPTIONS CONCERNING THE MASS FLOW RATES

- All mass flow rates are relative to line 2, that is, $\mathrm{z}_{2}=1.0 \mathrm{lb} / \mathrm{hr}$

- Let $r$ be the return ratio, then (for 8 stages)

$$
z_{10}=8 r \frac{z_{9}+z_{3}}{2}=R\left(z_{9}+z_{3}\right)
$$

(For 8 pressure stages $r$ is from 0.08 to 0.14 and $R$ from 0.32 to 0.56.$)$

- The ratio $z_{2} / z_{1}$ is given as $s$ ( $s$ is about $14 \%$ to $22 \%$ ). Other assumptions

- To simplify the calculations for the preheater, it is assumed that the strong solution entering the generator is at a temperature equal to: $\mathrm{T}_{2}=$ saturated Temp. at $\mathrm{x}_{1}$ and $\mathrm{P}_{\mathrm{C}}+15$ psia. 


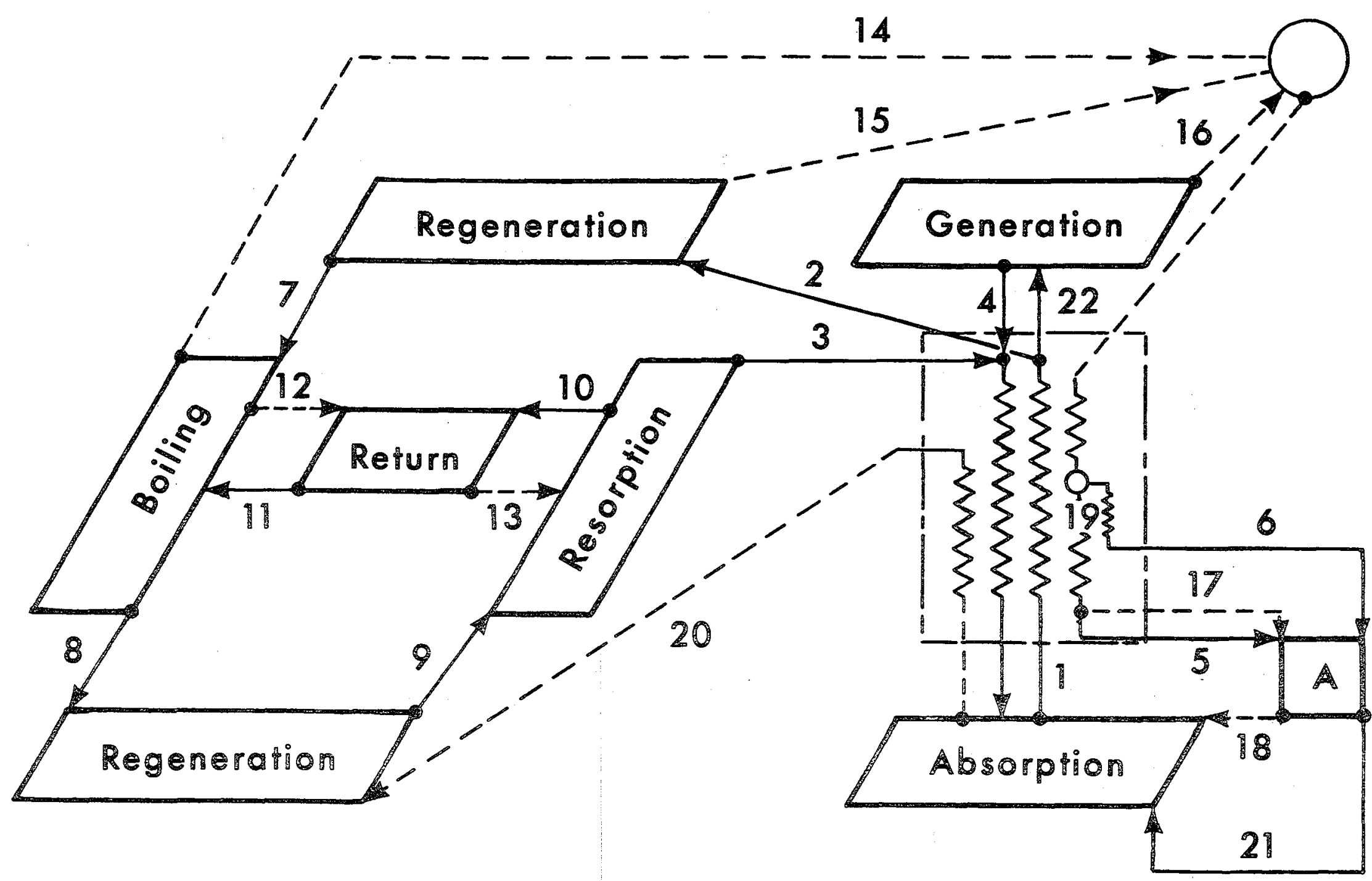

XBL $7812-13399$

Figure 3. Schematic system used to estimate the COP of cycle 2R. Box A represents the condenser, evaporator and precooler. 
Table 1. Assumptions concerning the properties of the lines in Figure 3 .

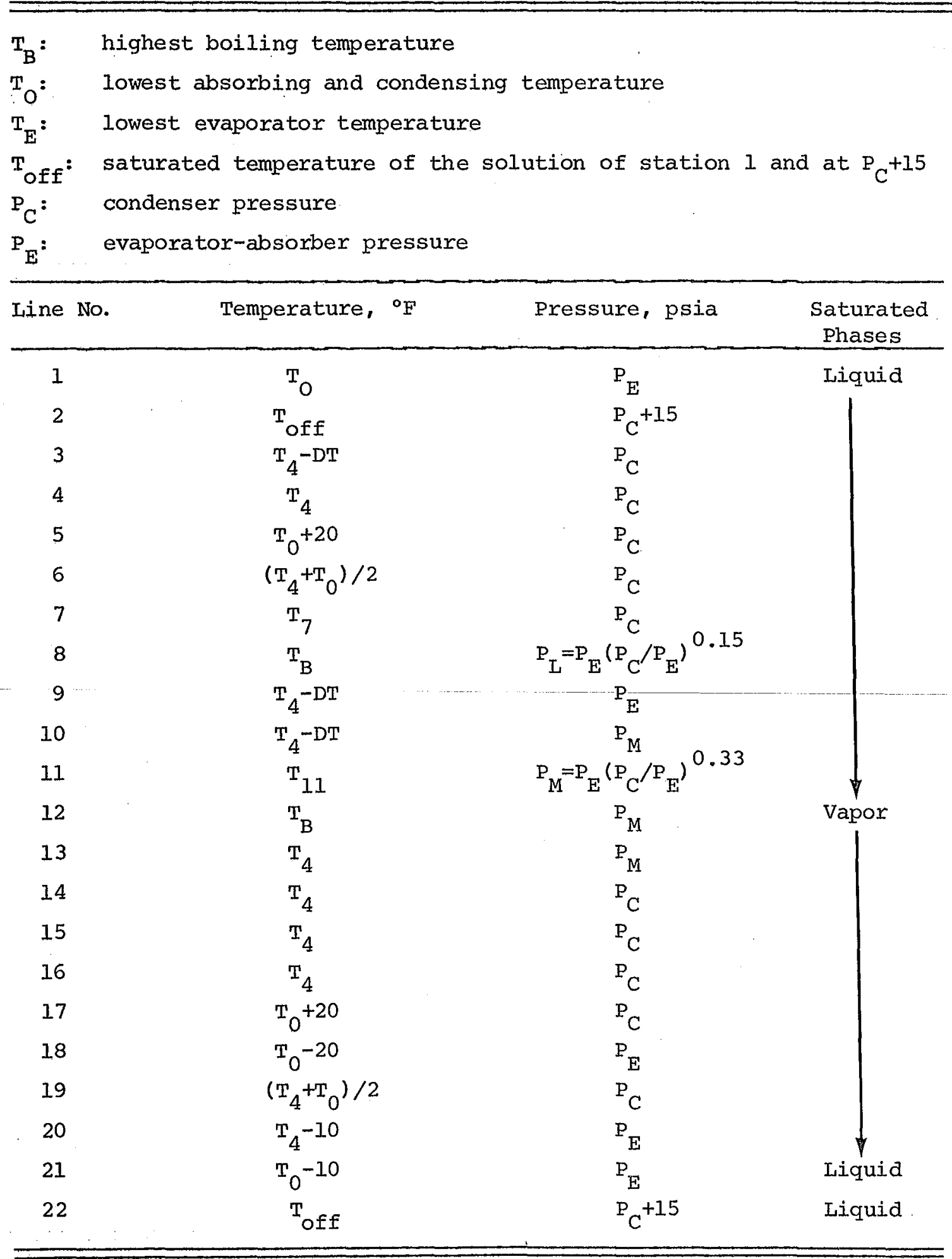


- Other heat exchanger characteristics are given as a temperature approach. For example, the precooler has a temperature approach of $10^{\circ} \mathrm{F}$ (lines 21 and 18 have a temperature of $\mathrm{T}_{0}-10^{\circ} \mathrm{F}$ ).

- DT is the difference between the highest temperature of the generation process $\left(\mathrm{T}_{4}\right)$ and the lowest temperature of the resorption process $\left(\mathrm{T}_{9}\right.$ and $\left.\mathrm{T}_{3}\right)$. DT is about $2^{\circ}$ to $6^{\circ} \mathrm{F}$. METHOD OF CALCULATION

The unknowns to be calculated are:

- the 21 mass flow rates, $z_{1}$ to $z_{21}$,

- the temperatures $\mathrm{T}_{7}, \mathrm{~T}_{4}$ and $\mathrm{T}_{11}$, for a total of 24 unknowns.

Eighteen mass and species balances can be written around the components of the system. There are three given mass distribution conditions, namely:

$$
\begin{aligned}
& z_{2}=1.0 ; \\
& z_{10}=8 r\left(z_{9}+z_{3}\right) / 2, \quad r=0.08 \text { to } 0.14 ;
\end{aligned}
$$

and

$$
\mathrm{z}_{2}=s \mathrm{z}_{1}, \mathrm{~s}=0.14 \text { to } 0.22 \text {, }
$$

or

$$
z_{2}=s z_{22} /(1-s) ;
$$

and 3 energy balances, namely:

$$
\begin{gathered}
\text { Return process - } z_{12} h_{12}+z_{10} h_{10}=z_{11} h_{11}+z_{13} h_{13} \\
\text { Regeneration }-z_{20} h_{20}+z_{8} h_{8}-z_{9} h_{9}=z_{15} h_{15}+z_{7} h_{7}-z_{2} h_{2}, \\
\text { Resorption - } z_{13} h_{13}+z_{9} h_{9}-z_{10} h_{10}-z_{3} h_{3}= \\
z_{16} h_{16}+z_{4} h_{4}-\left(z_{1}-z_{2}\right) h_{2} .
\end{gathered}
$$

Thus, there are 24 equations for 24 unknowns. The cooling load is calculated from: 


$$
Q_{E}=z_{18} h_{18}+z_{21} h_{21}-z_{17} h_{17}-z_{5} h_{5}-z_{6} h_{6}
$$

where $h_{17}$ is evaluated at the outlet of the condenser, that is, at saturated liquid at $T_{C}$ and $x_{17^{*}} x_{17}$ is the saturated concentration of the vapor at $\mathrm{P}_{\mathrm{C}}$ and $\mathrm{T}_{\mathrm{C}}+20^{\circ} \mathrm{F}$. Lines 5 and 6 are expanded directly into the precooler.

The heat input $\Omega_{B}$ is calculated from:

$$
\begin{aligned}
& \mathrm{Q}_{\mathrm{B}}=\mathrm{z}_{14} \mathrm{~h}_{14}+\mathrm{z}_{12} \mathrm{~h}_{12}+\mathrm{z}_{8} \mathrm{~h}_{8}-\mathrm{z}_{7} \mathrm{~h}_{7}-\mathrm{z}_{11} \mathrm{~h}_{11}, \\
& \operatorname{COP}=\mathrm{Q}_{\mathrm{E}} / \mathrm{Q}_{\mathrm{B}} .
\end{aligned}
$$

Table 2 summarizes the solution of the mass and species balances.

The above coefficients $F_{i}$ are calculated assuming $\mathrm{T}_{4}$ and $\mathrm{T}_{7}$ are known. Initial values can be taken as: $\mathrm{T}_{4}=\mathrm{T}_{\text {off }}+10^{\circ} \mathrm{F}$ and $\mathrm{T}_{7}=$ $\mathrm{T}_{\mathrm{B}}-10^{\circ} \mathrm{F}$. Values for the concentrations and enthalpies are taken (at known saturated $\mathrm{T}$ and $\mathrm{P}$ ) from "Physical and Thermodynamic Properties of Ammonia-Water Mixtures," Research Bulletin No. 34, IGT, AGA. Now, $\mathbb{T}_{7}$ is corrected by the energy balance of the regeneration process:

$$
\begin{aligned}
Q_{R} & =z_{20} h_{20}+z_{8} h_{8}-z_{9} h_{9}, \\
\text { Since } \quad z_{15} / z_{2} & =\left(Q_{R}-z_{7} h_{7}+z_{2} h_{2}\right) / z_{2} h_{15}=A . \\
z_{15} / z_{2} & =\left(x_{2}-x_{7}\right) /\left(x_{15}-x_{7}\right)=A \\
x_{7} & =\left(x_{2}-A x_{15}\right) /(1-A) .
\end{aligned}
$$

Therefore, $\mathrm{T}_{7}$ corrected $=$ table $\left(\mathrm{X}_{7}, \mathrm{P}_{\mathrm{C}}\right)$ and

$$
\mathrm{h}_{7}=\left[\text { table }\left(\mathrm{x}_{7}, \mathrm{~T}_{7}\right)+0.6 \mathrm{~h}_{7} \text { previous }\right] / 1.6
$$


Table 2. Mass flow rates as functions of $x$.

\begin{tabular}{|c|c|c|}
\hline $\begin{array}{l}\text { Solve the mass } \\
\text { balances for } \\
\text { the lines: }\end{array}$ & $\begin{array}{l}\text { To get these } \\
\text { mass flow rates: }\end{array}$ & ( $R$ and $S$ given) \\
\hline \multirow[t]{2}{*}{$8 ; 9 ; 20$} & $z_{9}=F_{9} z_{20}$ & $F_{9}=\left(x_{20}-x_{8}\right) /\left(x_{9}-x_{8}\right)$ \\
\hline & $z_{8}=F_{8} z_{20}$ & $F_{8}=F_{9}-1$ \\
\hline \multirow[t]{4}{*}{$9 ; 13 ; 10 ; 3$} & $z_{3}=F_{3} z_{20}$ & $F_{3}=F_{9}\left[(1-R) x_{13}-\left(x_{9}-R x_{10}\right)\right]$ \\
\hline & & $/\left[(1+R) x_{13}-\left(x_{3}+r x_{10}\right)\right]$ \\
\hline & $\mathrm{z}_{13}=\mathrm{F}_{13} \mathrm{Z}_{20}$ & $F_{13}=F_{3}(1+R)-F_{9}(1-R)$ \\
\hline & $z_{10}=F_{10} z_{20}$ & $F_{10}=R\left(F_{9}+F_{3}\right)$ \\
\hline \multirow[t]{2}{*}{$7 ; 15 ; 2$} & $\mathrm{z}_{7}=\mathrm{F}_{7} \mathrm{z}_{2}$ & $F_{7}=\left(x_{15}-x_{2}\right) /\left(x_{15}-x_{7}\right)$ \\
\hline & $\mathrm{z}_{15}=\mathrm{F}_{15^{2}} \mathrm{z}_{2}$ & $F_{15}=\left(1-F_{7}\right)$ \\
\hline \multirow[t]{2}{*}{$\begin{array}{l}8 ; 14 ; 7 ; 10 ; 13 \\
\text { Solve for } z_{8} \text { and } \\
\text { set } z_{8}=F_{8} z_{20} \text { to } \\
\text { get } z_{20}\end{array}$} & $\mathrm{z}_{20}=\mathrm{F}_{20} \mathrm{Z}_{2}$ & $\begin{aligned} F_{20}= & F_{7}\left(x_{14}-x_{7}\right) /\left(F_{8}\left(x_{14}-x_{8}\right)-\right. \\
& F_{10}\left(x_{14}-x_{10}\right)+\left(x_{14}-x_{13}\right) F_{1}\end{aligned}$ \\
\hline & $z_{14}=F_{14} Z_{2}$ & $F_{14}=F_{7}+F_{20}\left(F_{10}-F_{13}-F_{8}\right)$ \\
\hline
\end{tabular}


$\mathrm{T}_{4}$ is corrected by the energy balance of the resorption process:

$$
\begin{gathered}
\mathrm{Q}_{G}=z_{13} h_{13}+z_{9} h_{9}-z_{10} h_{10}-z_{3} h_{3} \\
z_{16} /\left(z_{1}-z_{2}\right)=\left[Q_{G}+\left(z_{1}-z_{2}\right) h_{2}-z_{4} h_{4}\right] /\left(z_{1}-z_{2}\right) h_{16}=B
\end{gathered}
$$

where $z_{1}, z_{4}$ are given by the mass and species balances for the lines 16,4 and $(1-2)$ as:

$$
\begin{aligned}
& z_{1}=z_{2} / s, \\
& z_{4}=\left(x_{16}-x_{2}\right)\left(z_{1}-z_{2}\right) /\left(x_{16}-x_{4}\right),
\end{aligned}
$$

and

$$
\mathrm{x}_{4}=\left(\mathrm{x}_{2}-\mathrm{Bx} \mathrm{x}_{16}\right) /(1-\mathrm{B})
$$

Therefore:

$$
\mathrm{T}_{4} \text { corrected }=\text { Table }\left(\mathrm{X}_{4} ; \mathrm{P}_{\mathrm{C}}\right)
$$

and

$$
\mathrm{h}_{4}=\left[\mathrm{Tab} l \mathrm{e}\left(\mathrm{x}_{4}, \mathrm{~T}_{4}\right)+0.6 \mathrm{~h}_{4} \text { previous }\right] / 1.6
$$

This iterative procedure converges very fast, and five to seven iterations should produce results accurate to a few hundredths of a degree, ${ }^{\circ} \mathrm{F}$.

As of now the following results have been obtained:

$$
\begin{aligned}
& \mathrm{T}_{7} \text { and } \mathrm{T}_{4} \\
& \mathrm{Z}_{2}=\mathrm{Z}_{2} \\
& \mathrm{Z}_{3}=\mathrm{F}_{20} \mathrm{~F}_{3} \mathrm{Z}_{2} \\
& \mathrm{Z}_{7}=\mathrm{F}_{7} \mathrm{~F}_{2} \\
& \mathrm{Z}_{8}=\mathrm{F}_{20} \mathrm{~F}_{8} \mathrm{Z}_{2} \\
& \mathrm{Z}_{9}=\mathrm{F}_{20} \mathrm{~F}_{9} \mathrm{Z}_{2}
\end{aligned}
$$




$$
\begin{aligned}
z_{10} & =F_{20} F_{10} z_{2} \\
z_{13} & =F_{20} F_{13} z_{2} \\
z_{14} & =F_{14} z_{2} \\
z_{15} & =F_{15} z_{2} \\
z_{20} & =F_{20} z_{2} \\
z_{1} & =z_{2} / s \\
\text { and } \quad z_{16} & =B\left(z_{1}-z_{2}\right) \\
z_{4} & =\left(x_{16}-x_{2}\right)\left(z_{1}-z_{2}\right) /\left(x_{16}-x_{4}\right) .
\end{aligned}
$$

$\mathrm{z}_{12}, \mathrm{z}_{11}$ and $\mathrm{T}_{11}$ are now calculated from the mass and species balances for lines $7,14,8,11,12$ and the enthalpy balance of the return process: let $h_{11}=h_{10}$ (for a first guess, to be corrected),

$$
\begin{aligned}
& a=z_{13}-z_{10}, \\
& b=z_{13} h_{13}-z_{10} h_{10}, \\
& c=z_{13} x_{13}-z_{10} x_{10},
\end{aligned}
$$

and $\quad \mathrm{d}=\mathrm{b}-\mathrm{ah}_{12}$.

Then:

$$
\begin{aligned}
& z_{11}=a /\left(h_{12}-h_{11}\right), \\
& z_{12}=a+z_{11}, \\
& x_{11}=\left(z_{12} x_{12}-\mathrm{c}\right) / z_{11}, \\
& T_{11}=\text { Table }\left(x_{11}, P_{M}\right), \\
& h_{11}=\left[\text { Table }\left(x_{11}, T_{11}\right)+0.6 h_{11}\right] / 1.6 .
\end{aligned}
$$

With this corrected value of $h_{11}$, recalculations can be made for $z_{11}$ ' $\mathrm{z}_{12}, \mathrm{~T}_{11}$, and $\mathrm{h}_{11}$. The convergence of $\mathrm{T}_{11}$ should be obtained in less than seven iterations. 
The computer program for this system should be simple, as shown in the following flow chart (Figure 4):

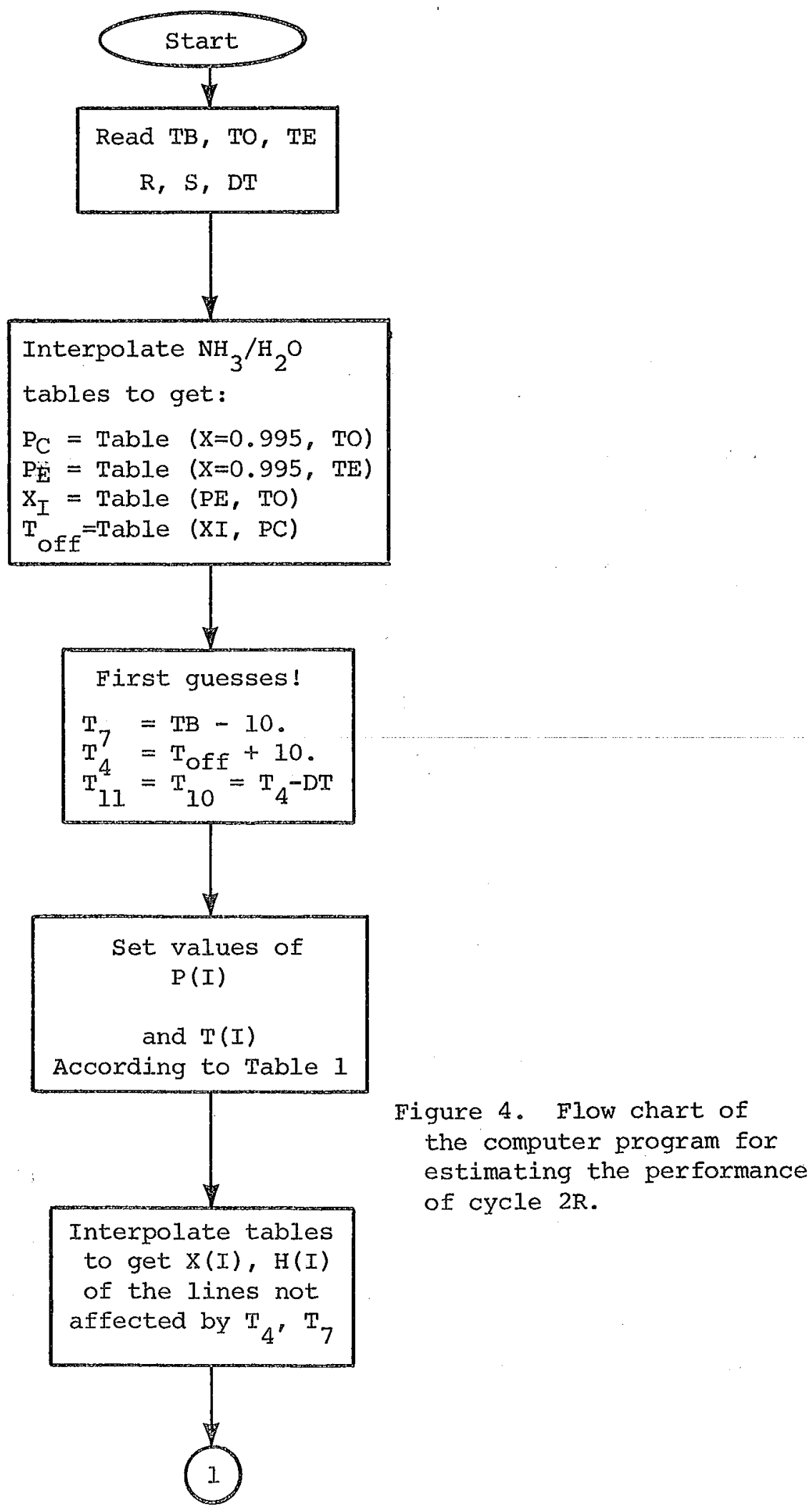




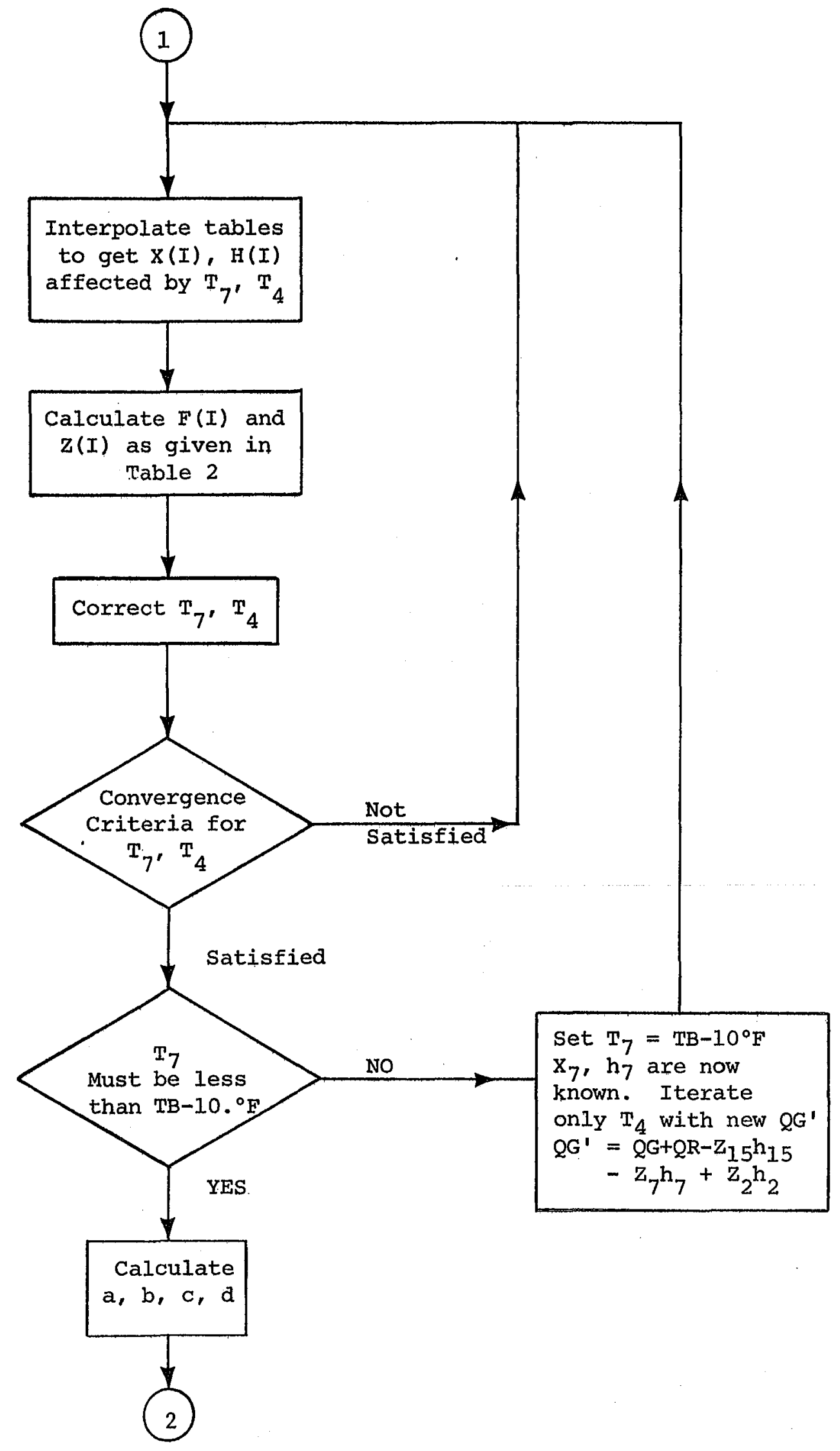




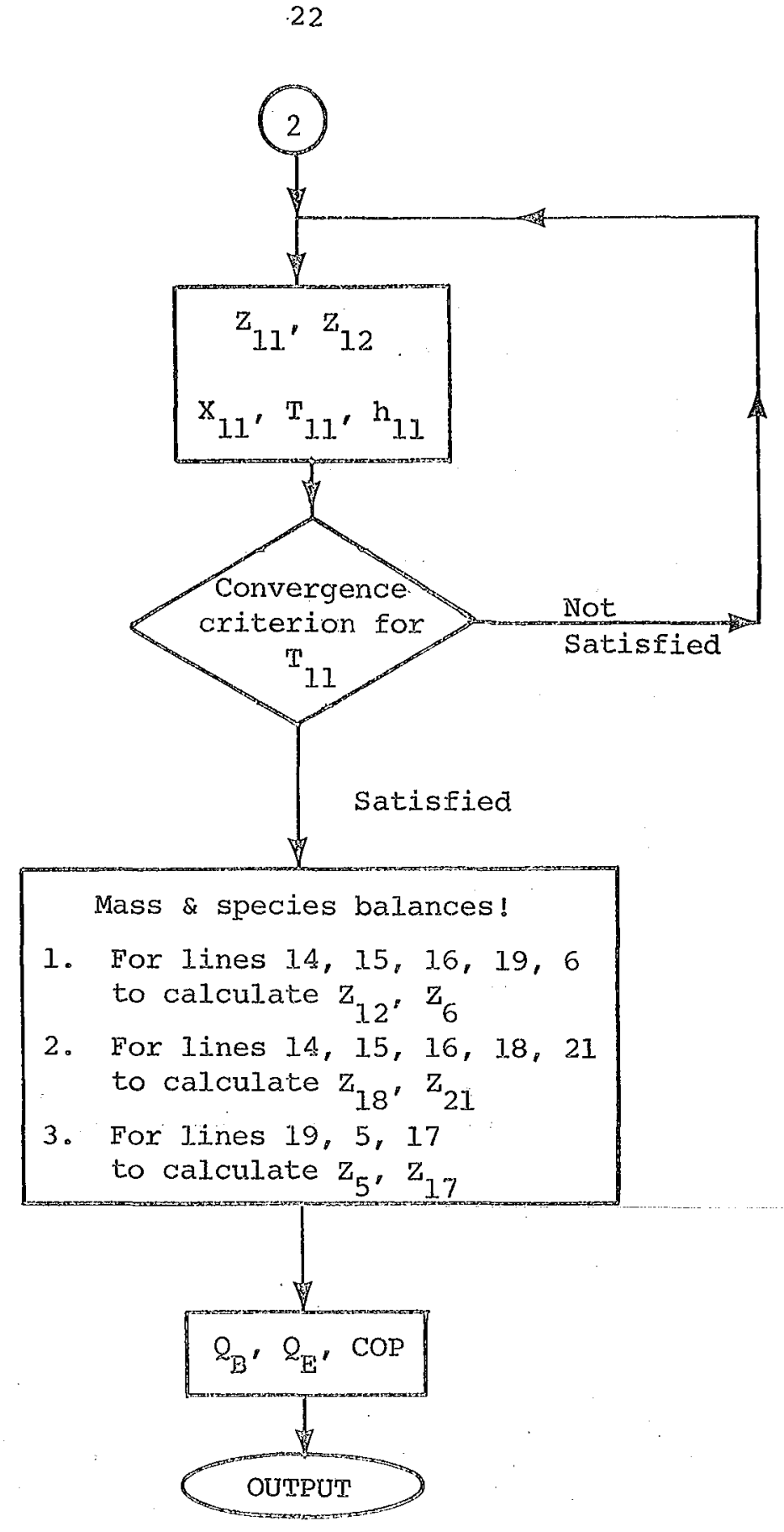


RESULTS

Calculated COP are plotted in Figures 5-11 versus some important parameters. The computer outputs are listed in Appendix I.

In figure 5, the COP of cycle $2 \mathrm{R}$ is compared to other cycles, namely, the common-condenser double-effect cycle, the cycle $I R$, and the basic single-effect cycle. (A detailed description of cycle IR can be found in Reference 1, of the basic single-effect cycle in Reference 2, and of the common condenser double-effect cycle in Appendix II.)

Figure 5 shows that cycle $2 R$ performs as well as the single-effect cycle at low boiler temperatures and as well as the double-effect at high temperatures. The COP of cycle $2 \mathrm{R}$ increases continuously with boiler temperatures. While this is slightly less than the COP of cycle $1 R$, the configuration of cycle $2 \mathrm{R}$ is less complicated and only a careful cost analysis of the two systems can determine which one is better. The absence of cut-off temperatures is a feature of cycle $2 \mathrm{R}$ that makes it superior to double-effect cycles.

Figure 6 shows that at low condenser-absorber temperatures To' and high input temperatures $T_{B}$, the COP of cycle $2 R$ can be substantially higher than double-effect cycles.

Figure 7 shows that cycle $2 \mathrm{R}$ can be used as heat pump for heating purposes since it has an acceptable COP at $\mathrm{T}_{\mathrm{E}}$ of about $10^{\circ} \mathrm{F}$.

Figures 8-10 show the small influence of $r, s$ and DT on the performance of cycle $2 R$. 
The influence of the size of the preheater (or preheater effectiveness) is shown in Figure 11. It seems that the preheater effectiveness must be greater than 0.85 for good system performance. 


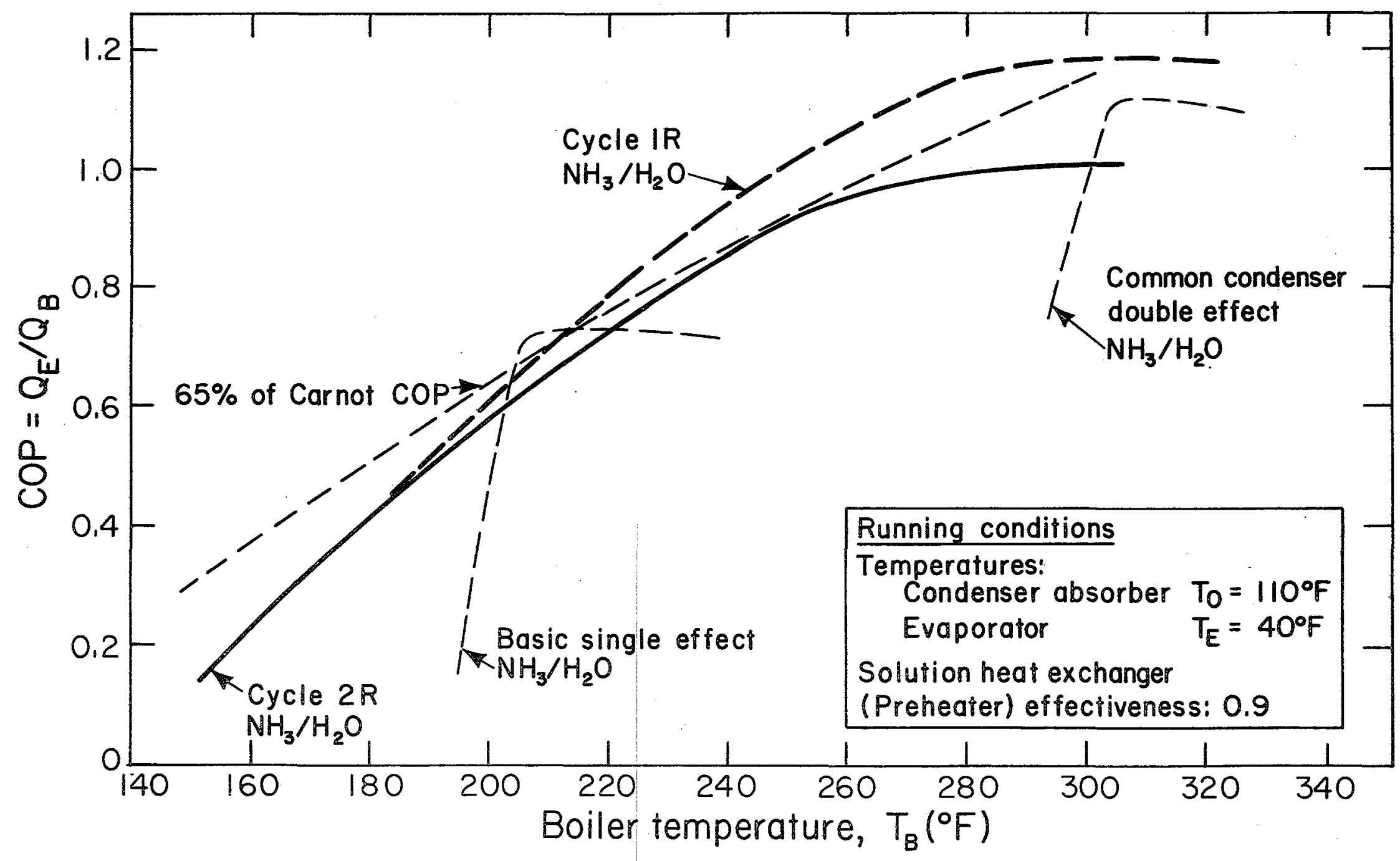
Figure 5. Calculated performance of cycle $2 \mathrm{R}$ using $\mathrm{NH}_{3} / \mathrm{H}_{2} \mathrm{O}$ mixtures. Carnot $\mathrm{COP}=\left(\mathrm{T}_{\mathrm{B}}-\mathrm{T}_{\mathrm{O}}\right) /\left(\mathrm{T}_{\mathrm{B}}+460\right)$
$\times\left(\mathrm{T}_{E}+460\right) /\left(\mathrm{T}_{\mathrm{O}}-\mathrm{T}_{\mathrm{E}}\right)$. 


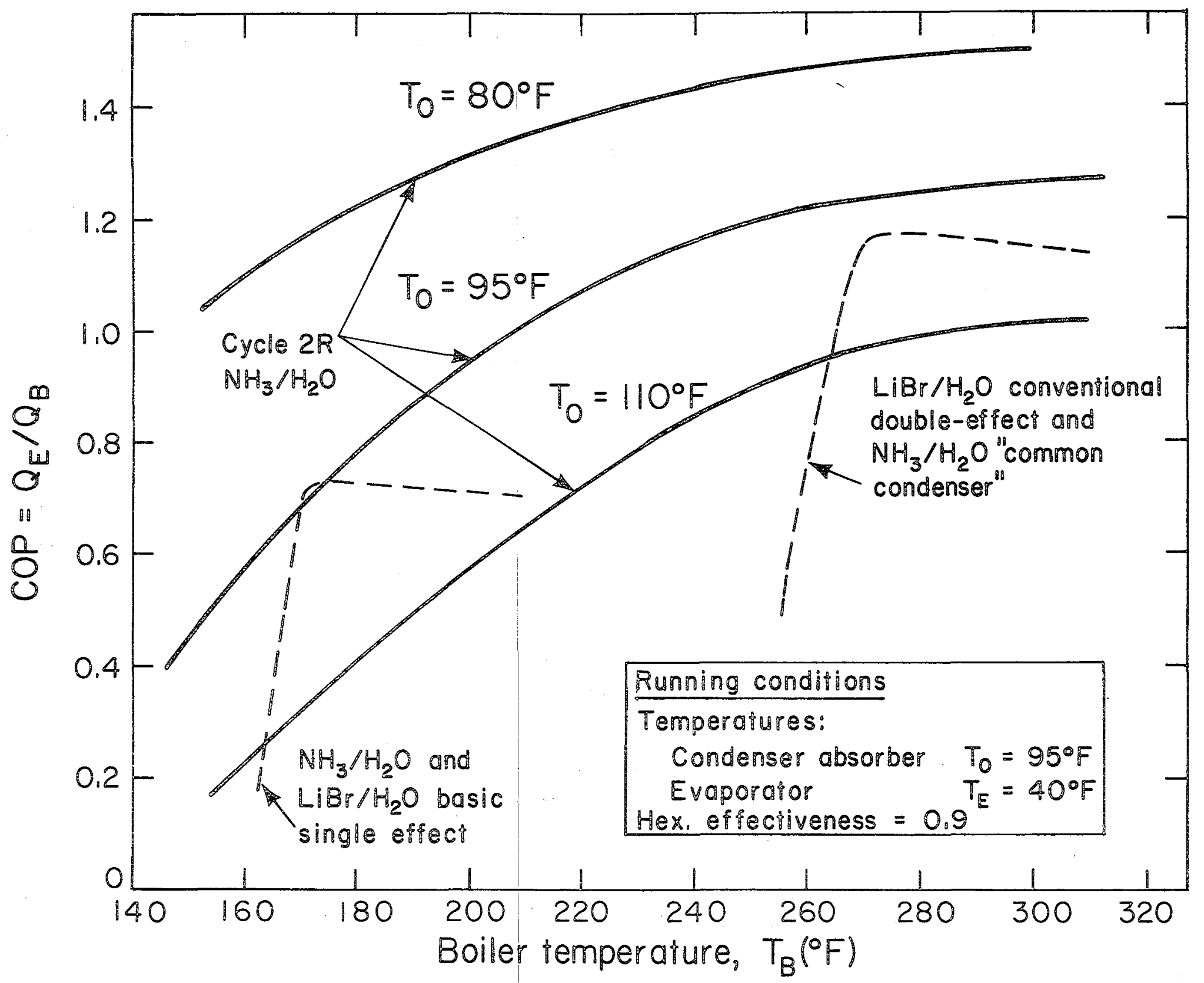

Figure 6. Calculated performance of cycle $2 \mathrm{R}$ using $\mathrm{NH}_{3} / \mathrm{H}_{2} \mathrm{O}$ mixtures. 


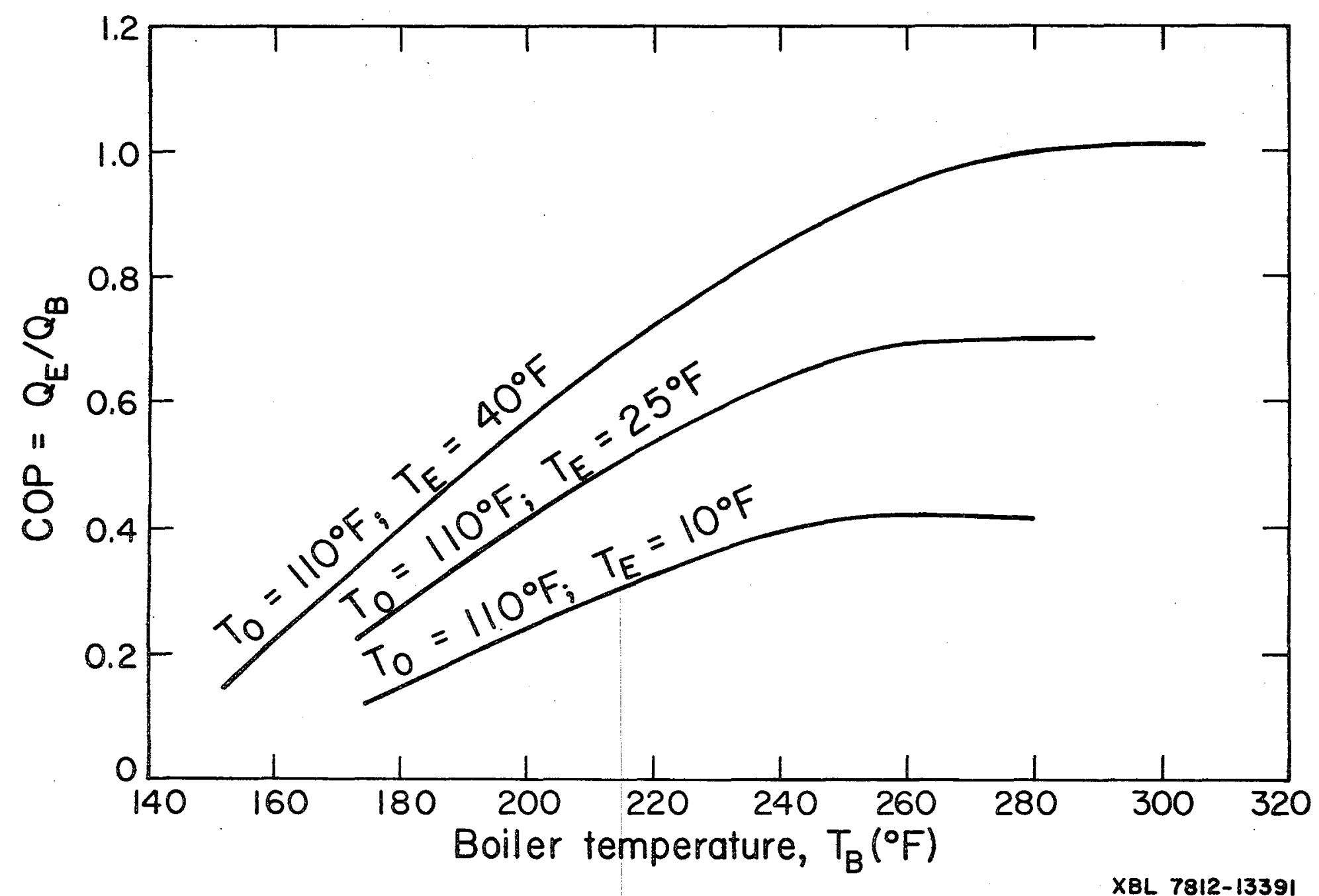

Figure 7. Calculated performance of cycle $2 \mathrm{R}$ using $\mathrm{NH}_{3} / \mathrm{H}_{2} \mathrm{O}$ mixtures. 


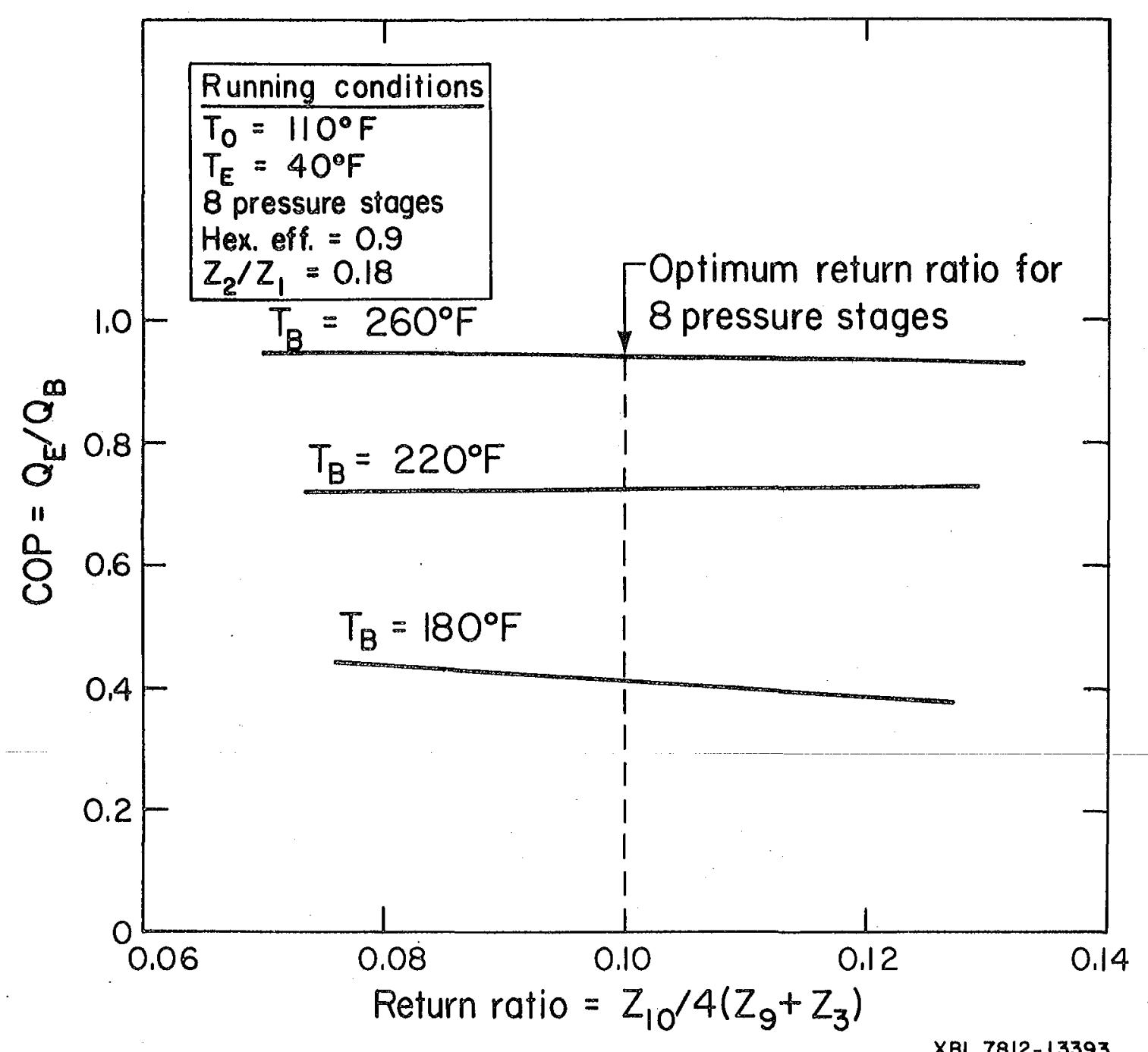

Figure 8. Small influence of the return ratio $r$ on the COP of cycle $2 R$. 


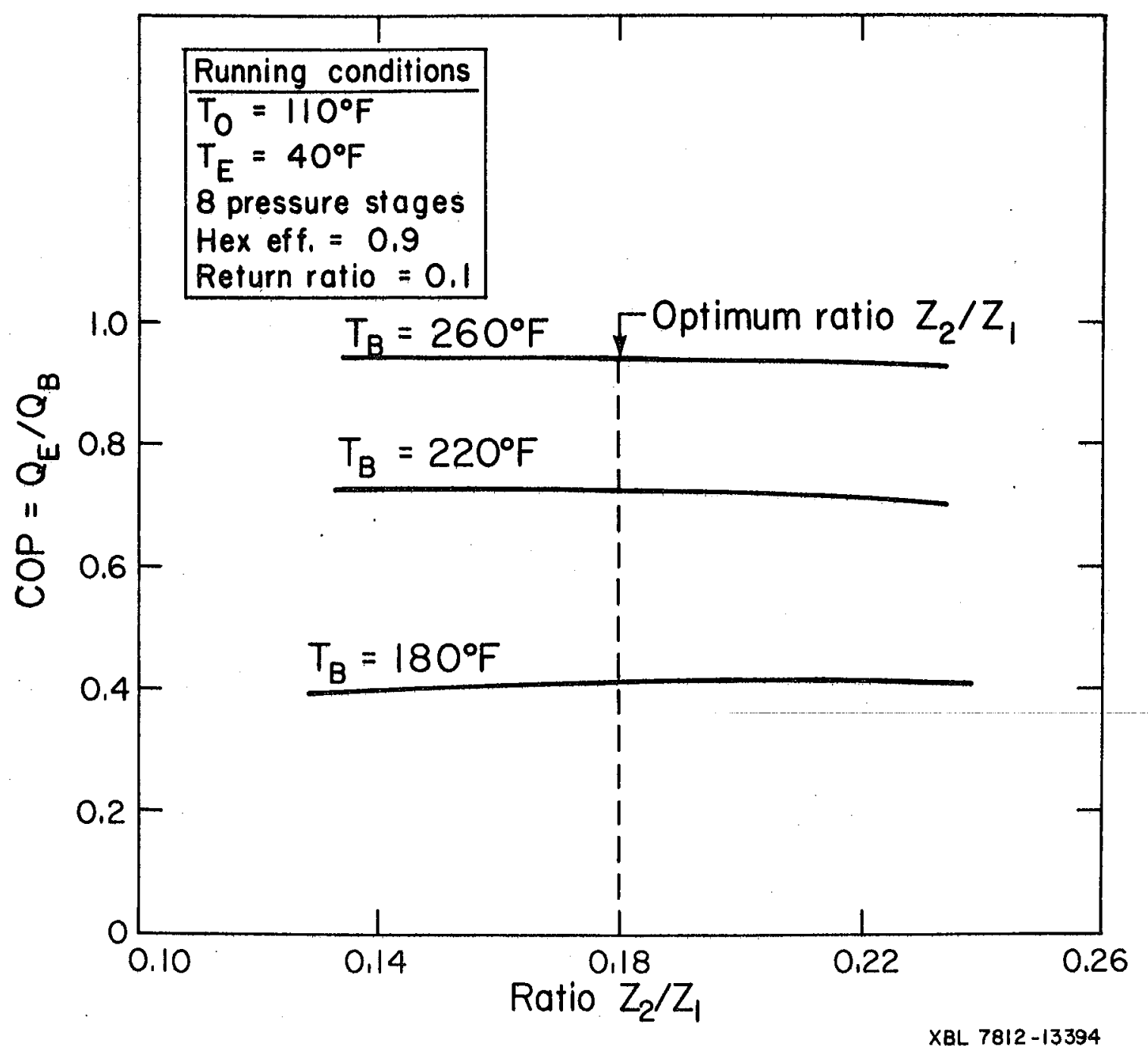

Figure 9. Small influence of the splitting ratios $=z_{2} / z_{1}$ on the COP of cycle 2R. 


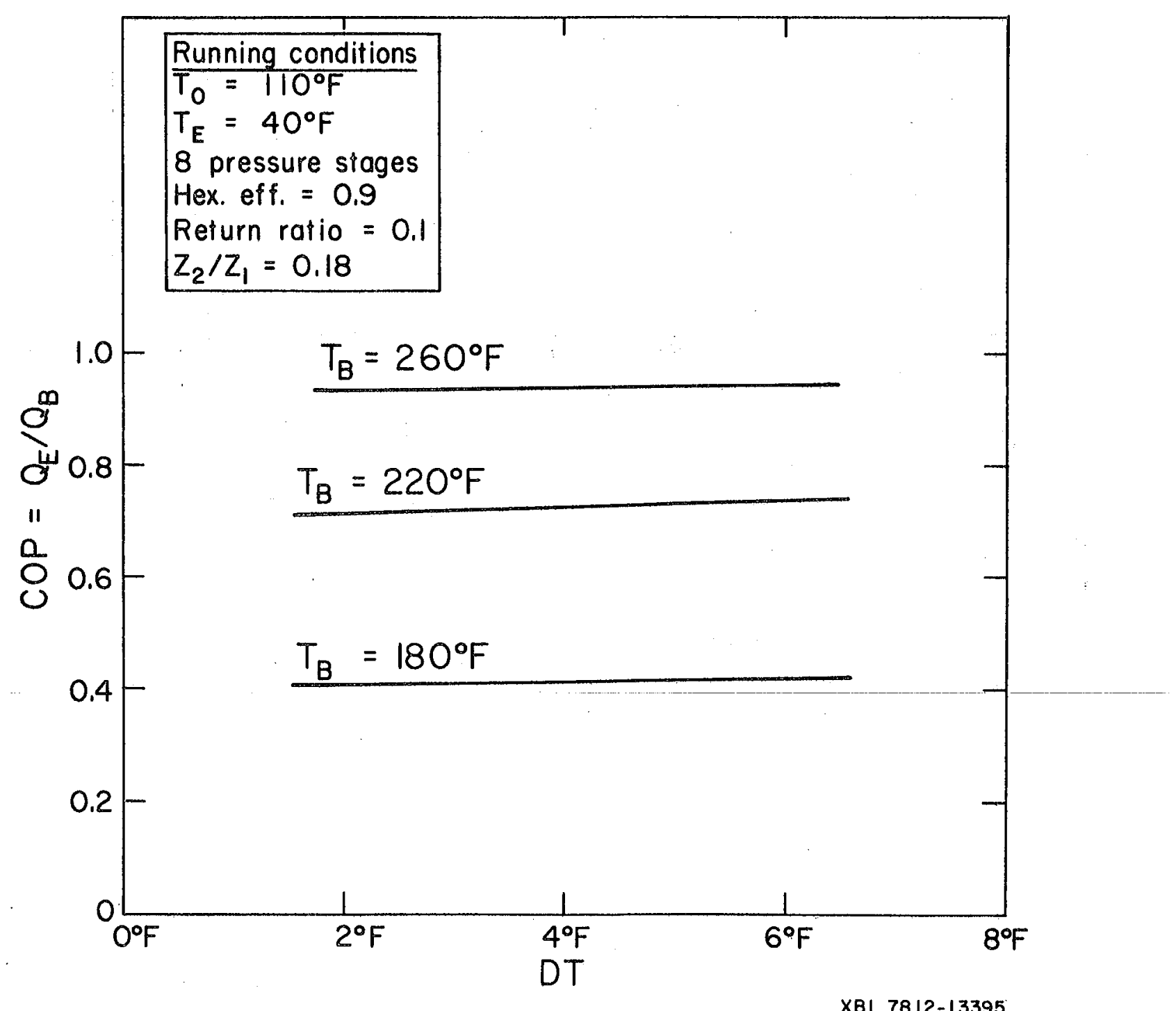

Figure 10. Small influence of DT on the COP of cycle $2 \mathrm{R}$. 


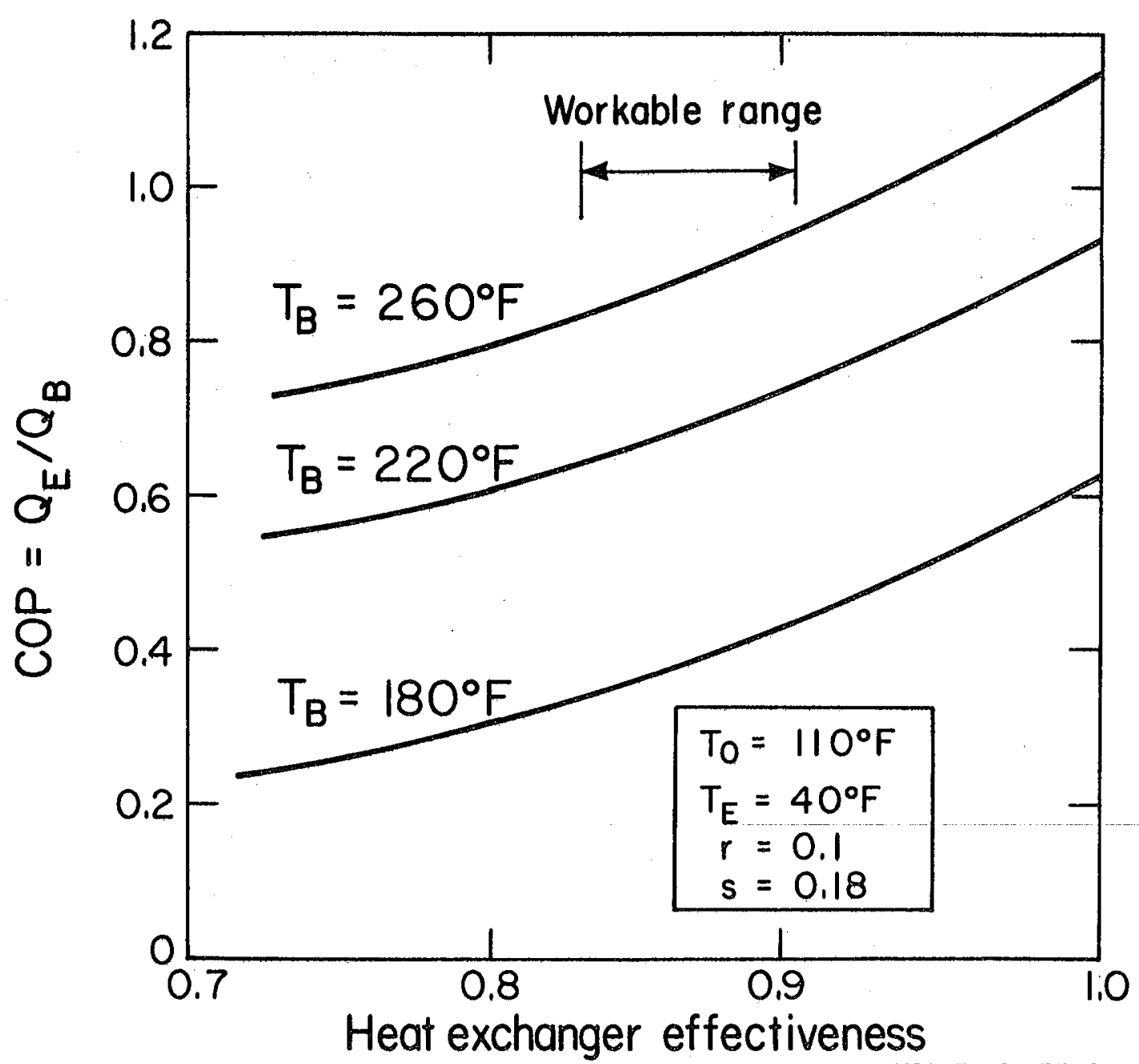

XBL 7812-13392

Figure 11. Estimated influence of preheater effectiveness on the COP of cycle $2 R$. 
REFERENCES

1. Kim Dao, A New Absorption Cycle: The Single-effect Regenerative Absorption Refrigeration Cycle, Lawrence Berkeley Laboratory, Report LBL-6879, Feb. 1978.

2. Kim Dao, Mel Simmons, Richard Wolgast and Michael Wahlig, Performance of an Experimental Solar-Driven Absorption AirConditioner, Lawrence Berkeley Laboratory, Report LBL-5911, Jan. 1977. 
APPENDIX I. OTHER DOUBLE-EFFECT CYCLES

The "common condenser" double-effect cycle (Fig. A) is an alternative to the conventional double-effect cycle which cannot be used with $\mathrm{NH}_{3} / \mathrm{H}_{2} \mathrm{O}$ mixtures because the pressure in the generator of the first effect would be too high (about 900 psia). In the conventional double-effect cycle, the condensation of the refrigerant vapor generated from the first-effect generator releases heat to boil out refrigerant in the second-effect generator. In the "common condenser" cycle the refrigerant vapors generated by both generators are at the same pressure; they are subsequently rectified and condensed in the same condenser.

The "common condenser" cycle is essentially the coupling of two conventional single-effect cycles. The first single-effect cycle operates at high generator temperature to boil out refrigerant vapor at the common condenser pressure and absorbs refrigerant vapor at the common evaporator pressure (the evaporator is common to both coupled cycles). This absorption of vapor releases heat at a temperature high enough to boil out refrigerant in the generator of the second single-effect cycle.

The conventional double-effect cycle is also essentially the coupling of two single-effect cycles. The difference between the conventional and "common-condenser" cycles consists in the mode of coupling: For the conventional double-effect cycle, the coupling is between the first-effect condensing process and the second-effect generating process; for the "common condenser" cycle the coupling is 
between the first-effect absorption process and the second-effect generating process. 


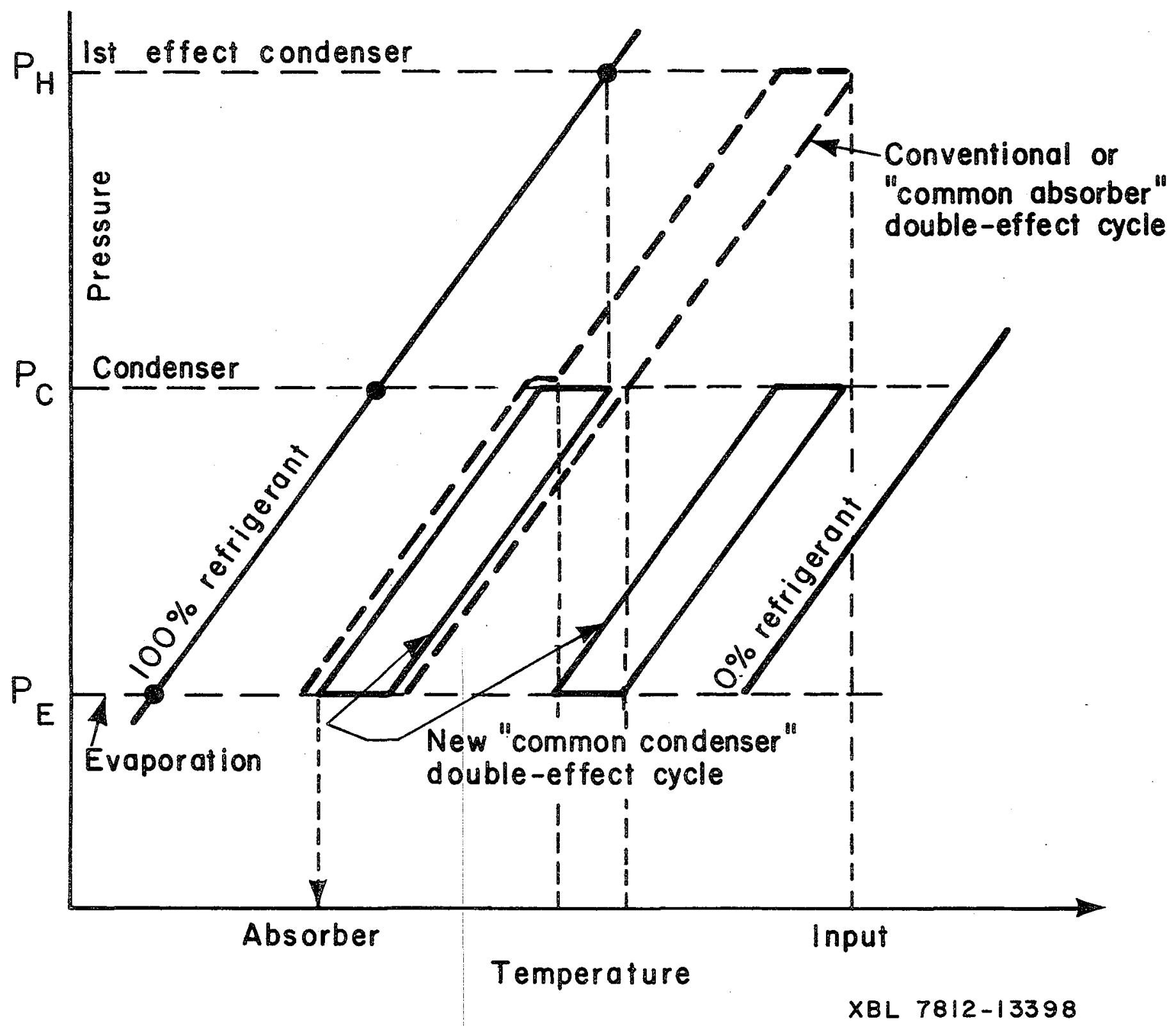

Figure A. Two possible configurations of double-effect absorption cycles. Both cycles have high, sharp cut-off temperatures. 
APPENDIX II

CALCULATED MASS FLOW RATES

AND OTHER RESULTS 


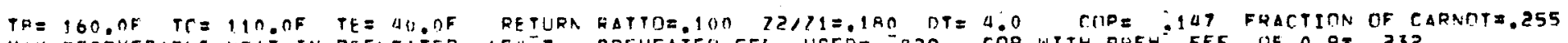

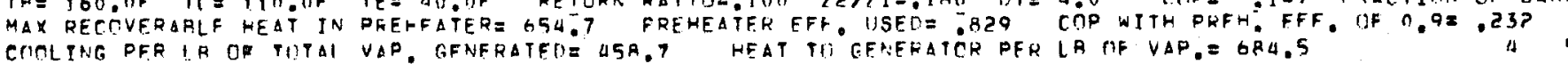

\begin{tabular}{|c|c|c|c|c|c|c|c|c|c|c|c|}
\hline LJNF & TFMO & FRESS & en+Ae & ENTHAIPY & MASS HLIJW & LINE & TEMP & PRF 55 & CTNC & ENTHALPY & $M \Delta S S F L \cap W$ \\
\hline $\begin{array}{c}1 \\
2 \\
3 \\
4 \\
5 \\
6 \\
7 \\
8 \\
0 \\
10 \\
11\end{array}$ & $\begin{array}{l}110.0 \\
190.9 \\
202.4 \\
206.4 \\
120.0 \\
158.2 \\
148.9 \\
160.0 \\
202.0 \\
202.4 \\
100.1\end{array}$ & $\begin{array}{r}73: 0 \\
260: 9 \\
245: 9 \\
24599 \\
245=9 \\
245: 9 \\
24529 \\
9796 \\
73=0 \\
109: 0 \\
109: 0\end{array}$ & $\begin{array}{l}.4715 \\
.4715 \\
.4403 \\
.4277 \\
.8667 \\
.5975 \\
.4451 \\
.3534 \\
.2110 \\
.2790 \\
.3190\end{array}$ & $\begin{array}{r}-23.5 \\
71.2 \\
80.2 \\
44.9 \\
58.2 \\
-3.7 \\
39.0 \\
39.2 \\
115.1 \\
99.9 \\
79.9\end{array}$ & $\begin{array}{r}5.5556 \\
1.0000 \\
.8670 \\
4.1816 \\
.0054 \\
.0092 \\
1.5492 \\
1.7926 \\
1.1016 \\
.9074 \\
.9154\end{array}$ & $\begin{array}{l}12 \\
13 \\
14 \\
15 \\
16 \\
17 \\
18 \\
10 \\
20 \\
21 \\
22\end{array}$ & $\begin{array}{l}169.0 \\
206.4 \\
206.4 \\
206.4 \\
2116.4 \\
120.0 \\
100.0 \\
150.2 \\
202.4 \\
100.0 \\
10 h .0\end{array}$ & $\begin{array}{r}109.0 \\
109.0 \\
245.0 \\
245.0 \\
205.0 \\
245.9 \\
73.0 \\
245.9 \\
73.0 \\
73.0 \\
26109\end{array}$ & $\begin{array}{l}.9712 \\
.9075 \\
.9608 \\
.9608 \\
9608 \\
.9989 \\
.9956 \\
9027 \\
9637 \\
.5069 \\
.4715\end{array}$ & $\begin{array}{r}623.2 \\
693.3 \\
640.3 \\
640.3 \\
640.3 \\
89.6 \\
583.3 \\
506.1 \\
706.6 \\
-33.6 \\
74.2\end{array}$ & $\begin{array}{r}.3808 \\
.3928 \\
.2913 \\
.5492 \\
.3740 \\
.1014 \\
.1078 \\
.1968 \\
.3910 \\
.0082 \\
.5556\end{array}$ \\
\hline
\end{tabular}

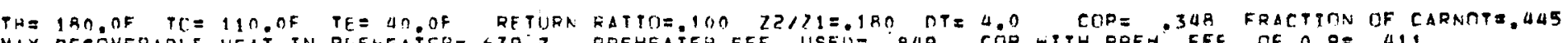

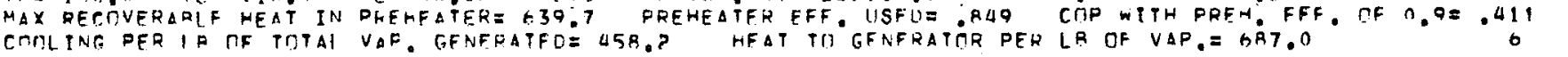

\begin{tabular}{|c|c|c|c|c|c|c|c|c|c|c|c|}
\hline LINF & TEMP & PRESS & CONC & ENTHALPY & MASS FLOWW & L. INF & IFMP & PRESS & CrNe. & FNPHALPY & MASS FLOW \\
\hline $\begin{array}{r}1 \\
2 \\
3 \\
11 \\
5 \\
6 \\
7 \\
2 \\
9 \\
10 \\
11\end{array}$ & 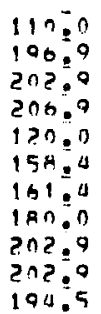 & $\begin{array}{r}73 ; 0 \\
260: 9 \\
245: 9 \\
245: 9 \\
245: 9 \\
245: 90 \\
245: 9 \\
97: 6 \\
73: 0 \\
109: 0 \\
1090\end{array}$ & $\begin{array}{l}.4715 \\
.14715 \\
.4399 \\
.11264 \\
.8667 \\
.5965 \\
.5836 \\
.2093 \\
.2105 \\
.7779 \\
.7995\end{array}$ & $\begin{array}{r}-23.5 \\
74.8 \\
20.7 \\
95.3 \\
58.0 \\
-3.8 \\
41.9 \\
70.8 \\
115.9 \\
100.6 \\
86.9\end{array}$ & $\begin{array}{r}5.5556 \\
1.0000 \\
.8945 \\
0.1710 \\
.0124 \\
.0210 \\
1.2978 \\
1.6750 \\
1.4468 \\
.9365 \\
.9411\end{array}$ & $\begin{array}{l}12 \\
13 \\
14 \\
15 \\
16 \\
17 \\
18 \\
19 \\
20 \\
? 1 \\
22\end{array}$ & $\begin{array}{l}180.0 \\
266.9 \\
206.9 \\
206.9 \\
216.0 \\
120.0 \\
100.0 \\
158.4 \\
20209 \\
100.0 \\
196.0\end{array}$ & $\begin{array}{r}109.0 \\
109.0 \\
245.9 \\
205.0 \\
245.9 \\
245.9 \\
13.0 \\
205.0 \\
73.0 \\
73.0 \\
260.9\end{array}$ & $\begin{array}{l}.9514 \\
0965 \\
0603 \\
09613 \\
09603 \\
.9980 \\
.9956 \\
.9921 \\
.8621 \\
.5069 \\
0715\end{array}$ & $\begin{array}{l}644.2 \\
684.02 \\
640.8 \\
640.8 \\
6110.8 \\
89.6 \\
583.3 \\
506.3 \\
707.6 \\
-33.6 \\
74.2\end{array}$ & $\begin{array}{r}.3889 \\
.3842 \\
.1750 \\
. .2978 \\
.3846 \\
.2284 \\
.2429 \\
.2408 \\
. .2283 \\
.0189 \\
4.5556\end{array}$ \\
\hline
\end{tabular}

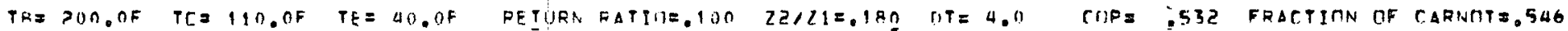
MAX DECTVERARLF HEAT IN PFETFATER= G20:9 FOEHEATER EFF. IISEDE

\begin{tabular}{|c|c|c|c|c|c|c|c|c|c|c|c|}
\hline LINF & TFMD & FAFSS & $\operatorname{rone}$ & ENTHALPY & MASS FLITW & LINE & $T F M P$ & PRESS & CONE & FNTHALPY & MASS FLOW \\
\hline $\begin{array}{c}1 \\
2 \\
3 \\
11 \\
5 \\
4 \\
7 \\
8 \\
0 \\
111 \\
11\end{array}$ & 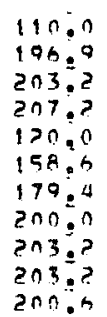 & $\begin{array}{r}73=0 \\
260=9 \\
245=9 \\
245=9 \\
245=9 \\
245=9 \\
245=9 \\
87=6 \\
73=0 \\
109=0 \\
109=0\end{array}$ & $\begin{array}{l}.4715 \\
.4715 \\
.1379 \\
.4253 \\
.8667 \\
.5956 \\
.5145 \\
.2476 \\
.2096 \\
.2764 \\
.2838\end{array}$ & $\begin{array}{r}-23.5 \\
74.2 \\
81.1 \\
85.8 \\
59.2 \\
-3.8 \\
56.2 \\
103.0 \\
116.5 \\
109 . ? \\
96.8\end{array}$ & $\begin{array}{l}5.5596 \\
1.0007 \\
.0170 \\
4.1521 \\
.0182 \\
.0311 \\
1.0967 \\
1.5774 \\
1.4852 \\
.9613 \\
.9623\end{array}$ & $\begin{array}{l}12 \\
13 \\
14 \\
15 \\
16 \\
17 \\
18 \\
19 \\
20 \\
21 \\
2 ?\end{array}$ & 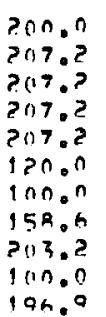 & $\begin{array}{r}109.0 \\
109.0 \\
245.0 \\
245.0 \\
245.0 \\
245.9 \\
73.0 \\
245.0 \\
73.0 \\
73.0 \\
260.0\end{array}$ & $\begin{array}{l}.9207 \\
.9056 \\
.9500 \\
.9590 \\
.9590 \\
.9989 \\
.9056 \\
99921 \\
.8608 \\
.5069 \\
.4715\end{array}$ & $\begin{array}{l}672.6 \\
644.8 \\
641.2 \\
641.2 \\
641.2 \\
89.6 \\
583.3 \\
596.4 \\
708.3 \\
-33.6 \\
74.2\end{array}$ & $\begin{array}{r}.3950 \\
.3939 \\
.0867 \\
.0967 \\
.3935 \\
.3301 \\
.3550 \\
.3523 \\
.0921 \\
.0280 \\
0.5556\end{array}$ \\
\hline
\end{tabular}




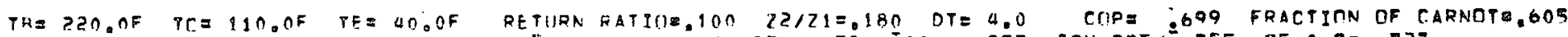

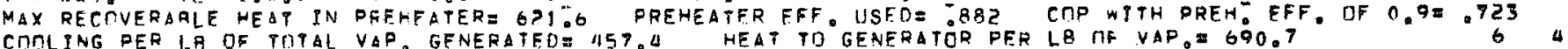

\begin{tabular}{|c|c|c|c|c|c|c|c|c|c|c|c|}
\hline LINF & TEMP & PRESS & CONC & ENTHALPY & MASS FLOW & LINE & TFMP & PRESS & CENC & ENTHALPY & MASS FLOW \\
\hline $\begin{array}{r}1 \\
2 \\
5 \\
4 \\
6 \\
6 \\
7 \\
8 \\
9 \\
10 \\
11\end{array}$ & $\begin{array}{l}14000 \\
190.9 \\
20306 \\
207.6 \\
120.0 \\
150.8 \\
20302 \\
20000 \\
203.6 \\
203.6 \\
200.1\end{array}$ & 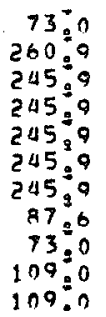 & $\begin{array}{l}.4715 \\
.4715 \\
.4368 \\
.4244 \\
.8667 \\
.5949 \\
.4379 \\
.1988 \\
.2072 \\
.2761 \\
.2624\end{array}$ & $\begin{array}{r}-23.5 \\
74.2 \\
81.5 \\
96.0 \\
58.2 \\
-4.0 \\
81.0 \\
137.6 \\
117.0 \\
101.9 \\
110.7\end{array}$ & $\begin{array}{r}5.5554 \\
1.0000 \\
.9371 \\
4.1548 \\
.0232 \\
.0307 \\
.9345 \\
1.0405 \\
1.5168 \\
.9815 \\
.9808\end{array}$ & $\begin{array}{l}12 \\
13 \\
14 \\
15 \\
16 \\
17 \\
19 \\
19 \\
20 \\
21 \\
22\end{array}$ & $\begin{array}{l}220.0 \\
207.6 \\
209.6 \\
207.6 \\
207.6 \\
170.0 \\
109.0 \\
158.8 \\
107.6 \\
100.0 \\
196.0\end{array}$ & $\begin{array}{r}109.0 \\
109.0 \\
245.0 \\
245.9 \\
245.9 \\
245.9 \\
73.0 \\
245.9 \\
73.0 \\
73.0 \\
260.0\end{array}$ & 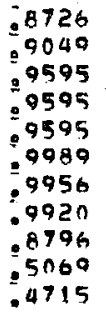 & $\begin{array}{l}708.5 \\
685.3 \\
649.8 \\
641.6 \\
649.6 \\
89.6 \\
593.3 \\
596.5 \\
696.8 \\
033.6 \\
74.2\end{array}$ & $\begin{array}{l}.4012 \\
04019 \\
.0196 \\
.0655 \\
.4008 \\
.4229 \\
.4501 \\
.4461 \\
.0222 \\
.0358 \\
4.5556\end{array}$ \\
\hline
\end{tabular}

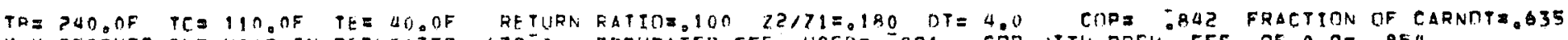

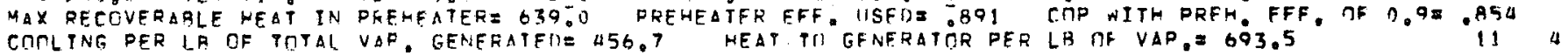

\begin{tabular}{|c|c|c|c|c|c|c|c|c|c|c|c|}
\hline LINE & TEMP & FRESS & CINE & ENTHALPY & MASS FLOWW & LINE & TFMP & PRESS & CENC. & ENTHALPY & MASS FLOW \\
\hline $\begin{array}{l}1 \\
2 \\
3 \\
4 \\
5 \\
6 \\
7 \\
6 \\
0 \\
10 \\
11\end{array}$ & 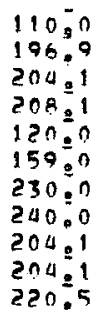 & $\begin{array}{r}73: 0 \\
260: 9 \\
245: 9 \\
245: 9 \\
245: 9 \\
245: 9 \\
245: 9 \\
87: 8 \\
73: 0 \\
109: 0 \\
109: 0\end{array}$ & $\begin{array}{l}.4715 \\
.4715 \\
.4353 \\
.4229 \\
.8067 \\
.5938 \\
.3630 \\
.1514 \\
.2075 \\
.2748 \\
.2346\end{array}$ & $\begin{array}{r}-23.5 \\
74.2 \\
82.1 \\
86.8 \\
58.2 \\
-4.1 \\
116.9 \\
171.9 \\
118.0 \\
192.5 \\
120.5\end{array}$ & $\begin{array}{r}5.5556 \\
1.0000 \\
.9497 \\
4.1426 \\
.0281 \\
.0483 \\
.8180 \\
1.4184 \\
1.5372 \\
.9046 \\
.9085\end{array}$ & $\begin{array}{l}12 \\
13 \\
14 \\
15 \\
16 \\
17 \\
18 \\
19 \\
20 \\
21 \\
22\end{array}$ & $\begin{array}{l}200.0 \\
208.1 \\
208.1 \\
208.1 \\
208.1 \\
120.0 \\
100.0 \\
159.0 \\
198.1 \\
100.0 \\
106.0\end{array}$ & $\begin{array}{r}109.0 \\
109.0 \\
245.9 \\
245.0 \\
245.9 \\
245.9 \\
73.0 \\
245.0 \\
73.0 \\
73.0 \\
260.9\end{array}$ & 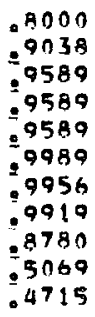 & $\begin{array}{l}746.3 \\
686.2 \\
642.1 \\
642.1 \\
642.1 \\
99.06 \\
593.3 \\
596.7 \\
697.9 \\
-33.6 \\
74.2\end{array}$ & $\begin{array}{r}.4109 \\
.4066 \\
.0124 \\
.1820 \\
.4132 \\
.5063 \\
.5391 \\
.5345 \\
.9188 \\
.0437 \\
4.5556\end{array}$ \\
\hline
\end{tabular}

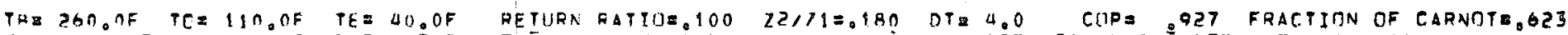

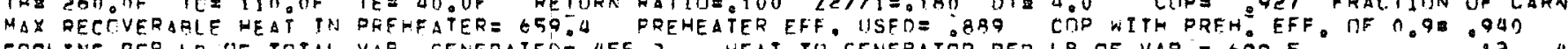

\begin{tabular}{|c|c|c|c|c|c|c|c|c|c|c|c|}
\hline INF & TFMP & PAESS & ETNC & ENTHALPY & MASS FLOWW & LINE & TFMP & PRESS & CONC & ENTHALPY & MASS FLOU \\
\hline $\begin{array}{l}1 \\
? \\
3 \\
4 \\
5 \\
6 \\
7 \\
2 \\
9 \\
14 \\
11\end{array}$ & $\begin{array}{l}110.0 \\
19690 \\
205.3 \\
200.3 \\
120.0 \\
159.7 \\
250.0 \\
260.0 \\
205.3 \\
205.3 \\
236.9\end{array}$ & 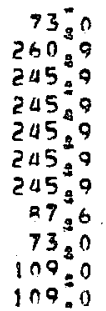 & $\begin{array}{l}.4715 \\
04715 \\
.47316 \\
.4396 \\
01193 \\
.8667 \\
.5910 \\
.3123 \\
.1104 \\
.20445 \\
.2717 \\
.1958\end{array}$ & $\begin{array}{r}-23.5 \\
74.2 \\
83.5 \\
88.2 \\
58.2 \\
-4.5 \\
147.4 \\
202.4 \\
120.1 \\
104.6 \\
156.8\end{array}$ & $\begin{array}{r}505556 \\
1.0000 \\
0.9549 \\
4.1137 \\
00335 \\
0.0580 \\
07532 \\
1.3567 \\
1.5473 \\
1.0007 \\
1.0115\end{array}$ & $\begin{array}{l}12 \\
13 \\
14 \\
15 \\
16 \\
17 \\
19 \\
19 \\
20 \\
21 \\
22\end{array}$ & $\begin{array}{l}200.0 \\
200.3 \\
209.5 \\
200.3 \\
209.3 \\
120.0 \\
100.0 \\
159.7 \\
199.3 \\
100.0 \\
196.0\end{array}$ & $\begin{array}{r}109.0 \\
100.0 \\
245.9 \\
245.9 \\
245.0 \\
245.9 \\
73.0 \\
245.9 \\
73.0 \\
73.0 \\
260.9\end{array}$ & 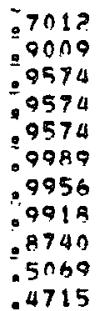 & $\begin{array}{r}799.6 \\
688.4 \\
643.5 \\
643.5 \\
643.5 \\
89.6 \\
583.3 \\
507.2 \\
900.3 \\
-33.6 \\
74.2\end{array}$ & $\begin{array}{r}.4194 \\
.4070 \\
.00905 \\
.2468 \\
.4416 \\
.5864 \\
.6250 \\
.0199 \\
.1906 \\
.0529 \\
4.5550\end{array}$ \\
\hline
\end{tabular}




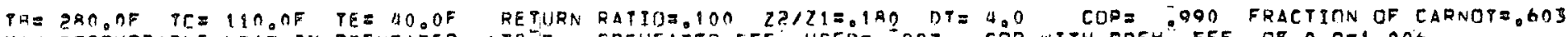

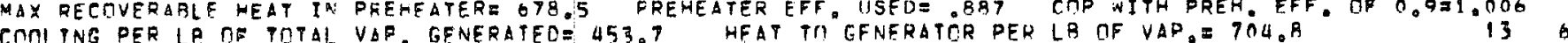

\begin{tabular}{|c|c|c|c|c|c|c|c|c|c|c|c|}
\hline LINE & TEMP & PRESS & RONE & ENTHALPY & MASS FLOW & LINE & TFMP & PRESS & CONE & ENTHALPY & MASS PLOW \\
\hline $\begin{array}{r}1 \\
2 \\
3 \\
4 \\
5 \\
6 \\
7 \\
2 \\
0 \\
10 \\
11\end{array}$ & 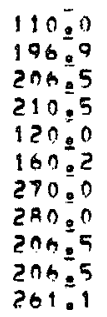 & $\begin{array}{r}73: 0 \\
260: 9 \\
245: 9 \\
245: 9 \\
245: 9 \\
245: 9 \\
245: 9 \\
87.6 \\
73: 0 \\
109: 0 \\
109.0\end{array}$ & $\begin{array}{l}.4715 \\
0475 \\
04281 \\
.4159 \\
08697 \\
.5884 \\
.2648 \\
0721 \\
.2019 \\
.2689 \\
.1423\end{array}$ & $\begin{array}{r}-23.5 \\
74.2 \\
84.0 \\
89.6 \\
58.2 \\
-4.8 \\
178.5 \\
232.6 \\
122.1 \\
106.5 \\
196.0\end{array}$ & $\begin{array}{r}5.5556 \\
1.0000 \\
0.0588 \\
4.0867 \\
.0385 \\
0.0673 \\
0.7010 \\
1.3037 \\
1.5564 \\
1.0061 \\
1.0228\end{array}$ & $\begin{array}{l}12 \\
13 \\
14 \\
15 \\
16 \\
17 \\
19 \\
10 \\
20 \\
21 \\
22\end{array}$ & $\begin{array}{l}280.0 \\
210.5 \\
210.5 \\
210.5 \\
210.5 \\
120.0 \\
100.0 \\
160.2 \\
200.5 \\
100.0 \\
196.9\end{array}$ & $\begin{array}{r}109.0 \\
109.0 \\
245.9 \\
245.9 \\
245.9 \\
245.9 \\
73.0 \\
245.9 \\
73.0 \\
73.0 \\
260.0\end{array}$ & $\begin{array}{l}.5693 \\
.8981 \\
.9560 \\
.9560 \\
.9560 \\
.9989 \\
.9956 \\
.9916 \\
.8702 \\
.5069 \\
.4715\end{array}$ & $\begin{array}{l}883.0 \\
690.5 \\
644.8 \\
644.8 \\
044.8 \\
89.6 \\
583.3 \\
507.6 \\
702.7 \\
-33.6 \\
74.2\end{array}$ & $\begin{array}{r}.4252 \\
.4085 \\
.0052 \\
.2990 \\
.4692 \\
.6573 \\
.7013 \\
.6958 \\
.2527 \\
.0619 \\
4.5556\end{array}$ \\
\hline
\end{tabular}

TRE $290.0 F \quad P C=110.0 F$ TEZ $40.0 F$ RETURN FATTO=.100 Z2121=.180 OT=

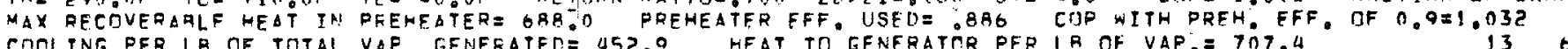

\begin{tabular}{|c|c|c|c|c|c|c|c|c|c|c|c|}
\hline$L \tau N_{F} F$ & TEMP & PRESS & CING & ENTHALPY & MASS FlOW & LINE & TEMP & PRESS & CONS. & ENTHALPY & MASS FLOW \\
\hline $\begin{array}{c}1 \\
2 \\
3 \\
4 \\
5 \\
6 \\
7 \\
8 \\
0 \\
10 \\
11\end{array}$ & 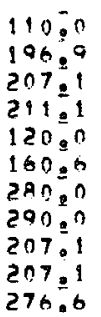 & $\begin{array}{r}73: 0 \\
260: 99 \\
245: 99 \\
245: 99 \\
245: 99 \\
245: 99 \\
245: 99 \\
97: 6 \\
73=0 \\
109: 00 \\
109.0\end{array}$ & $\begin{array}{l}.4795 \\
.4715 \\
.4263 \\
.4141 \\
.8667 \\
.5870 \\
.2424 \\
.0533 \\
.2072 \\
.8672 \\
.1099\end{array}$ & $\begin{array}{r}-23.5 \\
74 . ? \\
45.6 \\
90.4 \\
58.2 \\
-4.0 \\
194.1 \\
247.4 \\
123.1 \\
107.5 \\
220.2\end{array}$ & $\begin{array}{r}5.5556 \\
1.0000 \\
.9609 \\
4.0729 \\
0.0410 \\
0.0720 \\
0.6786 \\
1.2792 \\
1.5607 \\
1.0086 \\
1.0301\end{array}$ & $\begin{array}{l}12 \\
13 \\
14 \\
15 \\
16 \\
17 \\
18 \\
19 \\
21 \\
21 \\
22\end{array}$ & $\begin{array}{l}290.0 \\
211: 1 \\
219: 1 \\
291.1 \\
219.1 \\
120.0 \\
100.0 \\
160.6 \\
201.1 \\
100.0 \\
196.9\end{array}$ & $\begin{array}{r}109.0 \\
109.0 \\
245.9 \\
245.0 \\
245.9 \\
245.0 \\
73.0 \\
245.0 \\
73.0 \\
73.0 \\
260.9\end{array}$ & $\begin{array}{l}.4887 \\
.8966 \\
.9553 \\
.9553 \\
.9553 \\
.9989 \\
.9956 \\
.9915 \\
.8682 \\
.5069 \\
.4715\end{array}$ & $\begin{array}{r}932.3 \\
691.6 \\
645.5 \\
645.5 \\
645.5 \\
89.6 \\
583.3 \\
597.9 \\
703.9 \\
.33 .6 \\
74.2\end{array}$ & $\begin{array}{r}.4303 \\
.4088 \\
.0008 \\
.3214 \\
.4831 \\
.6907 \\
.7374 \\
.7317 \\
.2815 \\
.0663 \\
4.5556\end{array}$ \\
\hline
\end{tabular}

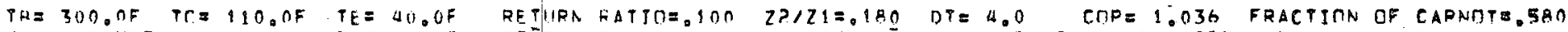

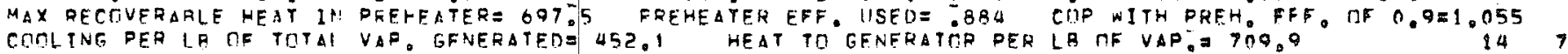

\begin{tabular}{|c|c|c|c|c|c|c|c|c|c|c|c|}
\hline LINF & TFMP & FRESS & roje & ENTHALPY & MASS FLחW & LINE & TFMP & PRESS & cone & FNTHALPY & MASS FLOW \\
\hline $\begin{array}{r}1 \\
? \\
3 \\
13 \\
5 \\
6 \\
4 \\
2 \\
0 \\
10 \\
11\end{array}$ & $\begin{array}{l}11000 \\
19609 \\
20707 \\
21109 \\
12000 \\
16009 \\
29000 \\
30000 \\
20797 \\
20797 \\
29500\end{array}$ & $\begin{array}{r}7390 \\
260 \% 9 \\
245 \% 9 \\
245 \% 9 \\
245 \% 9 \\
245 \% 9 \\
245 \% 9 \\
87 \% 6 \\
7390 \\
1090 \\
1090\end{array}$ & $\begin{array}{l}.4715 \\
01975 \\
04244 \\
01924 \\
02667 \\
.5857 \\
02208 \\
0.0345 \\
01985 \\
.2656 \\
00731\end{array}$ & $\begin{array}{l}-23.5 \\
74.0 ? \\
90.3 \\
91.0 \\
59.2 \\
-5.01 \\
209.7 \\
202.0 \\
1240.3 \\
108.5 \\
249.1\end{array}$ & $\begin{array}{r}5.5556 \\
1.0000 \\
09626 \\
4.0585 \\
00435 \\
.00766 \\
06583 \\
102552 \\
1.5635 \\
1.00104 \\
1.00392\end{array}$ & $\begin{array}{l}12 \\
13 \\
911 \\
15 \\
18 \\
18 \\
12 \\
19 \\
20 \\
21 \\
22\end{array}$ & $\begin{array}{l}30000 \\
211907 \\
2110.7 \\
2110 \% \\
2190.7 \\
120.0 \\
10000 \\
10009 \\
20107 \\
10000 \\
19600\end{array}$ & $\begin{array}{l}10909 \\
109.0 \\
24509 \\
245.9 \\
245.9 \\
245.9 \\
73.0 \\
245.9 \\
75.0 \\
7300 \\
260.9\end{array}$ & $\begin{array}{l}03974 \\
09950 \\
09545 \\
9545 \\
99545 \\
99989 \\
09956 \\
09914 \\
08660 \\
05069 \\
04795\end{array}$ & $\begin{array}{l}985.4 \\
692.8 \\
646.2 \\
646.2 \\
606.2 \\
99.0 \\
523.3 \\
598.1 \\
705.2 \\
033.6 \\
74.2\end{array}$ & $\begin{array}{l}.4383 \\
.4095 \\
.0040 \\
.3419 \\
.4967 \\
.7223 \\
.7916 \\
.7638 \\
.3095 \\
00708 \\
4.5556\end{array}$ \\
\hline
\end{tabular}




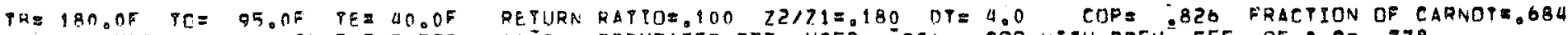

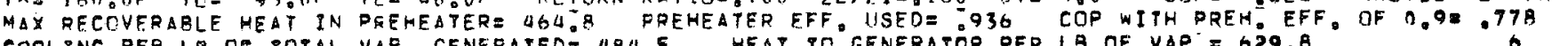

\begin{tabular}{|c|c|c|c|c|c|c|c|c|c|c|c|}
\hline INE & TEMP & FRESS & CONC & ENTHBLPY & MASS FLDW & LINE & TEMP & PRESS & CONE & FNTHALPY & MASS FLOW \\
\hline $\begin{array}{l}1 \\
2 \\
3 \\
4 \\
5 \\
6 \\
7 \\
2 \\
9 \\
10 \\
19\end{array}$ & 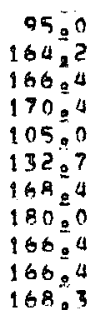 & $\begin{array}{r}73: 0 \\
210: 0 \\
195: 0 \\
195: 0 \\
195: 0 \\
195: 0 \\
195: 0 \\
94: 0 \\
73 \% 0 \\
101: 0 \\
101: 0\end{array}$ & $\begin{array}{l}.5260 \\
.5260 \\
.4985 \\
.4849 \\
.0580 \\
.6411 \\
.4919 \\
.2033 \\
.3045 \\
.3013 \\
.3558\end{array}$ & $\begin{array}{r}-38.2 \\
39.6 \\
40.6 \\
44.6 \\
38.1 \\
-13.6 \\
42.6 \\
72.0 \\
54.7 \\
45.3 \\
48.2\end{array}$ & $\begin{array}{r}5.5556 \\
1.0000 \\
.9448 \\
4.1995 \\
.0106 \\
.0107 \\
.0305 \\
1.5641 \\
1.5910 \\
1.0143 \\
1.0129\end{array}$ & $\begin{array}{l}12 \\
13 \\
14 \\
15 \\
16 \\
17 \\
19 \\
19 \\
20 \\
21 \\
22\end{array}$ & $\begin{array}{r}180.0 \\
170.4 \\
170.0 \\
170.4 \\
170.4 \\
105.0 \\
85.0 \\
132.7 \\
160.4 \\
85.0 \\
164.2\end{array}$ & $\begin{array}{r}101.0 \\
101.0 \\
195.0 \\
195.0 \\
195.0 \\
195.0 \\
73.0 \\
195.0 \\
73.0 \\
73.0 \\
210.0\end{array}$ & $\begin{array}{l}.9473 \\
.9584 \\
99828 \\
.982 A \\
.9828 \\
.9991 \\
.9979 \\
.9057 \\
.9554 \\
.5680 \\
.5260\end{array}$ & $\begin{array}{l}647.7 \\
636.0 \\
644.2 \\
614.2 \\
614.2 \\
71.8 \\
574.1 \\
545.8 \\
636.8 \\
-46.1 \\
39.6\end{array}$ & $\begin{array}{r}.3658 \\
.3681 \\
.0126 \\
.0695 \\
.3761 \\
.4310 \\
.4428 \\
.4416 \\
.0270 \\
.01161 \\
4.5556\end{array}$ \\
\hline
\end{tabular}

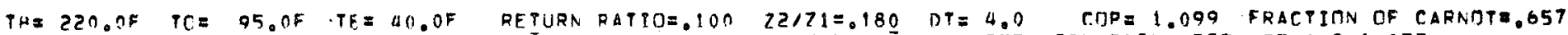

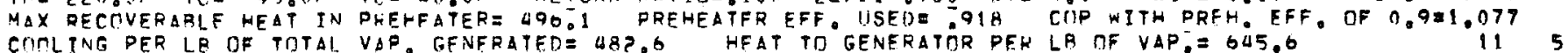

\begin{tabular}{|c|c|c|c|c|c|c|c|c|c|c|c|}
\hline LINE & TEMP & PRESS & CONS & ENTHALPY & MASS FLOW & LINE & TEMP & PRESS & CONC. & ENTHALPY & MASE FLOW \\
\hline $\begin{array}{l}1 \\
2 \\
3 \\
4 \\
5 \\
6 \\
7 \\
2 \\
9 \\
1 n \\
11\end{array}$ & $\begin{array}{l}95.0 \\
164.2 \\
168.8 \\
172.8 \\
105.0 \\
13390 \\
210.0 \\
2200 \\
168.8 \\
169.8 \\
183.0\end{array}$ & 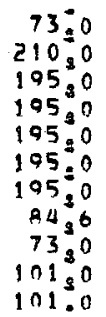 & $\begin{array}{l}.5260 \\
.5260 \\
.4906 \\
.4771 \\
.8580 \\
.6347 \\
.3683 \\
.1925 \\
.2981 \\
.3547 \\
.3160\end{array}$ & $\begin{array}{r}-38 . ? \\
39.6 \\
42.9 \\
47.0 \\
38.1 \\
-14.7 \\
93.4 \\
139.2 \\
58.6 \\
49.9 \\
71.1\end{array}$ & $\begin{array}{r}5.5556 \\
1.0000 \\
.9408 \\
4.1132 \\
.0175 \\
.0285 \\
.7427 \\
1.3703 \\
1.5916 \\
1.0130 \\
1.0049\end{array}$ & $\begin{array}{l}12 \\
13 \\
14 \\
15 \\
16 \\
17 \\
18 \\
19 \\
20 \\
21 \\
22\end{array}$ & $\begin{array}{r}220.0 \\
172.8 \\
172.8 \\
172.8 \\
172.8 \\
105.0 \\
45.0 \\
133.9 \\
162.8 \\
85.0 \\
164.2\end{array}$ & $\begin{array}{r}101.0 \\
101.0 \\
195.0 \\
195.0 \\
195.0 \\
195.0 \\
73.0 \\
195.0 \\
73.0 \\
73.0 \\
210.0\end{array}$ & $\begin{array}{l}.8602 \\
.9562 \\
9913 \\
99813 \\
9813 \\
99991 \\
99970 \\
9955 \\
.9523 \\
.5680 \\
.5260\end{array}$ & $\begin{array}{l}715.1 \\
638.9 \\
616.4 \\
616.4 \\
616.4 \\
71.8 \\
574.1 \\
586.5 \\
639.8 \\
646.1 \\
39.6\end{array}$ & $\begin{array}{l}.3541 \\
.3622 \\
.0232 \\
.2573 \\
.4420 \\
.6764 \\
.6946 \\
.6939 \\
.2213 \\
.0279 \\
4.5536\end{array}$ \\
\hline
\end{tabular}

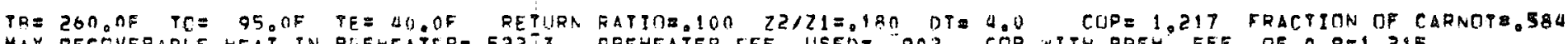

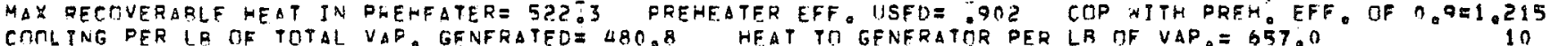

\begin{tabular}{|c|c|c|c|c|c|c|c|c|c|c|c|}
\hline $\operatorname{LINF}$ & TFMP & PEESS & CONC & ENTHALPY & MASS FL,OW & LINE & TFMP & PRESS & CONC & ENPHALPY & MASS FLOW \\
\hline $\begin{array}{c}1 \\
2 \\
3 \\
4 \\
5 \\
6 \\
7 \\
9 \\
9 \\
10 \\
11\end{array}$ & 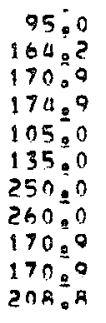 & $\begin{array}{r}7350 \\
290=0 \\
195=0 \\
195=0 \\
195: 0 \\
195: 0 \\
195=0 \\
94=6 \\
73: 0 \\
101: 0 \\
101: 0\end{array}$ & $\begin{array}{l}.5260 \\
05260 \\
.4835 \\
.1701 \\
.8580 \\
.6290 \\
.2075 \\
.1058 \\
.2024 \\
.3488 \\
.2501\end{array}$ & $\begin{array}{r}-38.2 \\
39.6 \\
45.1 \\
49.3 \\
38.1 \\
-15.6 \\
155.4 \\
203.6 \\
6 ? .1 \\
52.2 \\
113.0\end{array}$ & $\begin{array}{r}5.5556 \\
1.0000 \\
.0350 \\
9.0557 \\
.0237 \\
.0388 \\
06371 \\
1.2375 \\
1.5894 \\
1.0101 \\
1.0093\end{array}$ & $\begin{array}{l}12 \\
13 \\
14 \\
15 \\
16 \\
19 \\
99 \\
19 \\
20 \\
21 \\
22\end{array}$ & $\begin{array}{r}260.0 \\
174.9 \\
174.0 \\
174.9 \\
174.0 \\
1195.0 \\
85.0 \\
135.0 \\
164.0 \\
85.0 \\
164.2\end{array}$ & $\begin{array}{r}111.0 \\
101.0 \\
195.0 \\
195.0 \\
195.0 \\
195.0 \\
73.0 \\
195.0 \\
73.0 \\
73.0 \\
210.0\end{array}$ & 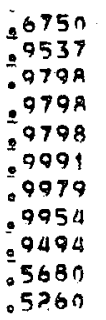 & $\begin{array}{l}815.1 \\
641.3 \\
618.4 \\
618.4 \\
618.4 \\
71.8 \\
574.1 \\
587.2 \\
642.7 \\
046.1 \\
39.6\end{array}$ & $\begin{array}{r}.3550 \\
.3566 \\
.0531 \\
.3629 \\
.4993 \\
.8533 \\
.8769 \\
.8769 \\
.3590 \\
.0384 \\
0.5556\end{array}$ \\
\hline
\end{tabular}




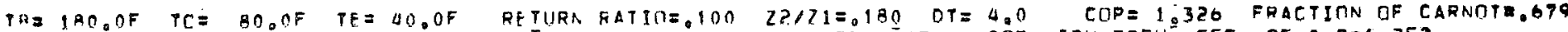

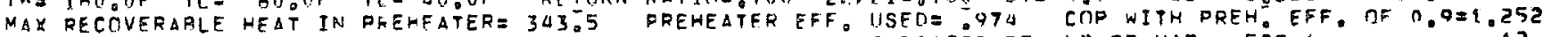

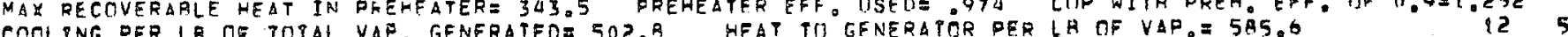

\begin{tabular}{|c|c|c|c|c|c|c|c|c|c|c|c|}
\hline LINE & PEMP & PRESS & CONe & ENTHALOY & MASS FLCIW & LINE & TFMP & PRESS & ERNE & ENPHALPY & MASS FLOW \\
\hline $\begin{array}{l}1 \\
2 \\
3 \\
1 \\
5 \\
6 \\
7 \\
8 \\
9 \\
10 \\
11\end{array}$ & 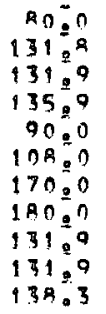 & $\begin{array}{r}73: 90 \\
167: 5 \\
152 ; 5 \\
152: 5 \\
152: 5 \\
152: 5 \\
152: 5 \\
81: 5 \\
73: 0 \\
93: 1 \\
93.1\end{array}$ & $\begin{array}{l}.5917 \\
.5917 \\
.5028 \\
.5470 \\
.8491 \\
.6899 \\
.4308 \\
.2870 \\
.4073 \\
.4477 \\
.4274\end{array}$ & $\begin{array}{r}-49.2 \\
9.0 \\
6.0 \\
9.1 \\
19.4 \\
-21.7 \\
43.0 \\
73.2 \\
1.9 \\
0.9 \\
8.1\end{array}$ & $\begin{array}{r}5.5556 \\
1.0000 \\
.9377 \\
4.0996 \\
.0078 \\
.0115 \\
.7139 \\
1.3565 \\
1.6247 \\
1.0250 \\
1.0126\end{array}$ & $\begin{array}{l}12 \\
13 \\
14 \\
15 \\
16 \\
17 \\
18 \\
19 \\
20 \\
21 \\
22\end{array}$ & $\begin{array}{l}180.0 \\
135.9 \\
135.9 \\
135.9 \\
135.0 \\
90.0 \\
70.0 \\
1198.0 \\
129.9 \\
70.0 \\
131.8\end{array}$ & $\begin{array}{r}93.1 \\
93.9 \\
152.5 \\
152.5 \\
152.5 \\
152.5 \\
73.0 \\
152.5 \\
73.0 \\
73.0 \\
167.5\end{array}$ & $\begin{array}{l}.9425 \\
.9852 \\
.9933 \\
.9933 \\
.9033 \\
.9993 \\
.9990 \\
.9978 \\
.9856 \\
.6486 \\
.5917\end{array}$ & $\begin{array}{r}651.6 \\
605.8 \\
593.7 \\
593.7 \\
593.7 \\
54.2 \\
565.7 \\
596.0 \\
602.8 \\
-51.8 \\
9.0\end{array}$ & $\begin{array}{r}.3256 \\
.3379 \\
.0444 \\
.2661 \\
.4569 \\
.7678 \\
.7742 \\
.7756 \\
.2682 \\
.7128 \\
4.5556\end{array}$ \\
\hline
\end{tabular}

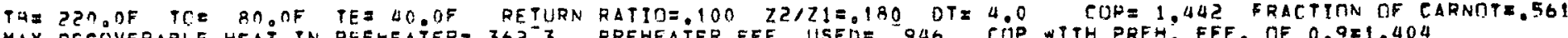

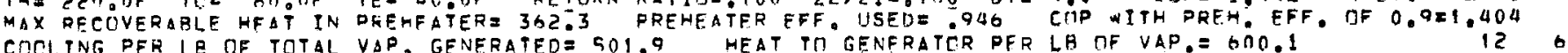

\begin{tabular}{|c|c|c|c|c|c|c|c|c|c|c|c|}
\hline LINF & TEMP & PRESS & CONE & ENTHALPY & MASS FLUW & LINE & TFMP & RFSS & CONC & ENTHALPY & MASS FLO \\
\hline $\begin{array}{r}1 \\
? \\
3 \\
4 \\
5 \\
6 \\
7 \\
8 \\
0 \\
10 \\
11\end{array}$ & $\begin{array}{r}80.0 \\
13108 \\
13400 \\
138.0 \\
90.0 \\
109.0 \\
210.0 \\
220.0 \\
13400 \\
13400 \\
152.0\end{array}$ & $\begin{array}{r}73: 0 \\
167: 5 \\
152: 5 \\
152: 5 \\
152: 5 \\
152: 5 \\
152: 5 \\
81: 5 \\
73: 0 \\
93: 1 \\
93.1\end{array}$ & $\begin{array}{l}.5917 \\
.5917 \\
.5541 \\
.5396 \\
.8491 \\
.6821 \\
.3205 \\
.1860 \\
.3961 \\
.4490 \\
.3972\end{array}$ & $\begin{array}{r}-49.2 \\
9.0 \\
7.6 \\
10.9 \\
18.4 \\
-23.1 \\
100.7 \\
140.8 \\
4.8 \\
3.2 \\
25.8\end{array}$ & $\begin{array}{r}5.5556 \\
1.0000 \\
.9224 \\
4.0236 \\
.0110 \\
.0164 \\
.5965 \\
1.1862 \\
1.0100 \\
1.0120 \\
.9022\end{array}$ & $\begin{array}{l}12 \\
13 \\
14 \\
15 \\
16 \\
17 \\
19 \\
10 \\
20 \\
21 \\
2 ?\end{array}$ & $\begin{array}{l}220.0 \\
138.0 \\
138.0 \\
138.0 \\
139.0 \\
90.0 \\
70.0 \\
10900 \\
128.0 \\
70.0 \\
139.0\end{array}$ & $\begin{array}{r}93.1 \\
93.1 \\
152.5 \\
152.5 \\
152.5 \\
152.5 \\
73.0 \\
152.5 \\
73.0 \\
73.0 \\
167.5\end{array}$ & $\begin{array}{l}.8455 \\
.9839 \\
.9927 \\
.9927 \\
.9927 \\
.9993 \\
.9990 \\
.9977 \\
.9842 \\
.6486 \\
.5917\end{array}$ & $\begin{array}{r}722.4 \\
607.6 \\
595.3 \\
505.3 \\
595.3 \\
54.2 \\
565.7 \\
576.6 \\
604.6 \\
-51.8 \\
9.0\end{array}$ & $\begin{array}{r}.3046 \\
.3253 \\
.0979 \\
.4035 \\
.5324 \\
1.0065 \\
1.0132 \\
1.0175 \\
.4236 \\
.0186 \\
4.5556\end{array}$ \\
\hline
\end{tabular}

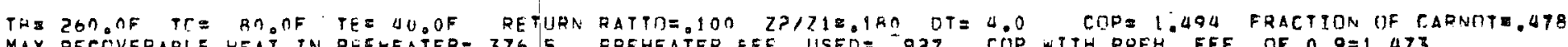

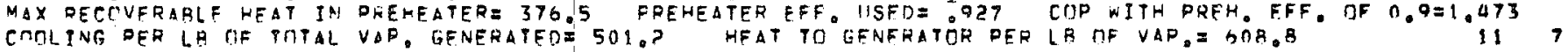

\begin{tabular}{|c|c|c|c|c|c|c|c|c|c|c|c|}
\hline LINE & TEMD & FRESS & CONC & ENTHALPY & MASS FLOW & LINE & TEMP & PRESS & CONE & ENTHALPY & MASS FLOW \\
\hline $\begin{array}{r}1 \\
2 \\
3 \\
4 \\
5 \\
6 \\
7 \\
8 \\
9 \\
10 \\
11\end{array}$ & $\begin{array}{r}2000 \\
13908 \\
13506 \\
15906 \\
9000 \\
10908 \\
25000 \\
26000 \\
13506 \\
13506 \\
17500\end{array}$ & $\begin{array}{r}73: 0 \\
16785 \\
15285 \\
152.5 \\
15285 \\
152.5 \\
152.5 \\
895 \\
7380 \\
938 \\
93.1\end{array}$ & $\begin{array}{l}.5917 \\
.5917 \\
.5477 \\
.5326 \\
.2491 \\
.6771 \\
07232 \\
.1004 \\
03914 \\
04361 \\
.3232\end{array}$ & $\begin{array}{r}-49.2 \\
9.0 \\
8.8 \\
12.2 \\
19.4 \\
-29.1 \\
164.07 \\
204.8 \\
7.0 \\
5.0 \\
60.8\end{array}$ & $\begin{array}{r}5.5556 \\
1.0000 \\
09118 \\
309696 \\
00134 \\
00702 \\
05208 \\
1.0727 \\
1.5909 \\
100046 \\
09851\end{array}$ & $\begin{array}{l}12 \\
13 \\
14 \\
15 \\
16 \\
17 \\
18 \\
19 \\
27 \\
21 \\
2 ?\end{array}$ & $\begin{array}{l}260.0 \\
139.6 \\
139.6 \\
139.6 \\
139.6 \\
90.0 \\
70.0 \\
109.8 \\
129.6 \\
70.0 \\
131.8\end{array}$ & $\begin{array}{r}93.1 \\
93.1 \\
152.5 \\
152.5 \\
152.5 \\
152.5 \\
73.0 \\
152.5 \\
73.0 \\
73.0 \\
167.5\end{array}$ & $\begin{array}{l}.6447 \\
09428 \\
09927 \\
.9922 \\
.9927 \\
09993 \\
.9990 \\
.9907 \\
09976 \\
09431 \\
.6486 \\
.5917\end{array}$ & $\begin{array}{r}833.7 \\
60900 \\
596.4 \\
596.4 \\
596.4 \\
54.2 \\
565.7 \\
577.9 \\
606.0 \\
051.8 \\
9.0\end{array}$ & $\begin{array}{r}.2992 \\
.3168 \\
01363 \\
04992 \\
05855 \\
1.1694 \\
1.1778 \\
1.1809 \\
05294 \\
00233 \\
405596\end{array}$ \\
\hline
\end{tabular}




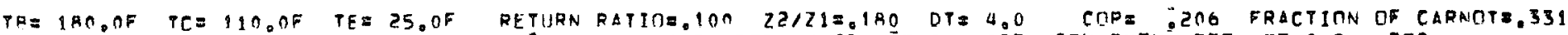

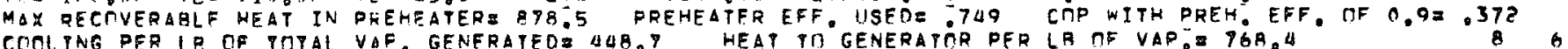

\begin{tabular}{|c|c|c|c|c|c|c|c|c|c|c|c|}
\hline INE & TEMP & PRESS & CONE & ENTHALPY & MASS FLOW & LINE & TEMP & PRESS & CONE & ENYHALPY & MASS FLOW \\
\hline $\begin{array}{r}1 \\
? \\
3 \\
4 \\
5 \\
4 \\
7 \\
2 \\
9 \\
10 \\
11\end{array}$ & 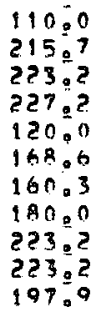 & $\begin{array}{r}53: 5 \\
260: 9 \\
245: 9 \\
245 \% 9 \\
245 \% 9 \\
24599 \\
245: 9 \\
67 \% 3 \\
53.5 \\
88.5 \\
88.5\end{array}$ & $\begin{array}{l}.4145 \\
04145 \\
03409 \\
03698 \\
.8667 \\
05539 \\
05885 \\
.2548 \\
01160 \\
01922 \\
.2549\end{array}$ & $\begin{array}{r}-22.9 \\
95.6 \\
106.8 \\
112.8 \\
59.2 \\
-8.3 \\
41.2 \\
80.1 \\
162.0 \\
142.7 \\
90.9\end{array}$ & $\begin{array}{r}5.5556 \\
1.0000 \\
.7694 \\
4.1965 \\
.0146 \\
.0256 \\
1.4998 \\
1.5354 \\
1.1606 \\
.7720 \\
.7684\end{array}$ & $\begin{array}{l}12 \\
13 \\
14 \\
15 \\
16 \\
17 \\
18 \\
19 \\
20 \\
21 \\
22\end{array}$ & $\begin{array}{l}180.0 \\
227.02 \\
229.2 \\
277.0 \\
227.2 \\
120.0 \\
100.0 \\
168.0 \\
223.2 \\
100.0 \\
215.7\end{array}$ & $\begin{array}{r}88.5 \\
88.5 \\
245.9 \\
245.9 \\
245.9 \\
245.9 \\
53.5 \\
245.9 \\
53.5 \\
53.5 \\
260.9\end{array}$ & 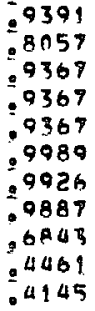 & $\begin{array}{l}654.3 \\
736.0 \\
663.2 \\
663.02 \\
663.2 \\
89.0 \\
588.1 \\
674.2 \\
801.2 \\
-34.06 \\
95.0\end{array}$ & $\begin{array}{r}.3772 \\
.3808 \\
.3556 \\
.0998 \\
.3590 \\
.1745 \\
.1928 \\
.1891 \\
0.3949 \\
.0220 \\
4.5596\end{array}$ \\
\hline
\end{tabular}

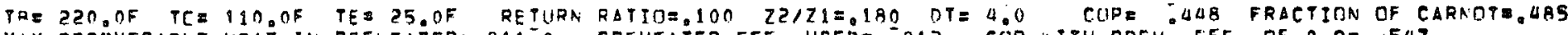
MAX RECOVERAGLE HEAT IN PFFHEATER= 811:0 FREHEATER EFF. USEDE 812 COP AITH PREH. EFF. DF 0.92 .547

\begin{tabular}{|c|c|c|c|c|c|c|c|c|c|c|c|}
\hline LINE & TEMP & FESS & CONE & ENTHALPY & MASS FLOW & LINE & TEMD & PRESS & CONE & ENTHALPY & MASS FLO \\
\hline $\begin{array}{c}1 \\
2 \\
3 \\
1 \\
5 \\
6 \\
7 \\
8 \\
0 \\
19 \\
11\end{array}$ & $\begin{array}{l}110.0 \\
215.7 \\
225.4 \\
229.4 \\
120.0 \\
169.7 \\
193.0 \\
220.0 \\
22504 \\
225.4 \\
219.5\end{array}$ & $\begin{array}{r}53: 5 \\
260: 9 \\
245: 9 \\
215: 9 \\
245: 9 \\
245: 9 \\
245: 9 \\
67: 3 \\
53.5 \\
88.5 \\
88.5\end{array}$ & $\begin{array}{l}.4145 \\
.4145 \\
.3752 \\
.3641 \\
08467 \\
.5497 \\
.4688 \\
.1548 \\
.11117 \\
.1868 \\
.7099\end{array}$ & $\begin{array}{r}-22.0 \\
95.6 \\
110.0 \\
116.0 \\
58.0 \\
08.6 \\
69.8 \\
148.9 \\
165.4 \\
146.5 \\
136.3\end{array}$ & $\begin{array}{r}5.5556 \\
1.0000 \\
.8773 \\
4.1526 \\
.0204 \\
.0513 \\
1.1168 \\
1.0345 \\
1.3238 \\
.8804 \\
.8747\end{array}$ & $\begin{array}{l}12 \\
13 \\
14 \\
15 \\
16 \\
17 \\
18 \\
19 \\
20 \\
21 \\
22\end{array}$ & $\begin{array}{l}220.0 \\
229.4 \\
220.4 \\
220.4 \\
220.4 \\
120.0 \\
100.0 \\
169.7 \\
225.4 \\
100.0 \\
215.7\end{array}$ & $\begin{array}{r}88.5 \\
83.5 \\
245.9 \\
245.9 \\
245.9 \\
245.9 \\
53.5 \\
245.9 \\
53.5 \\
53.5 \\
260.9\end{array}$ & 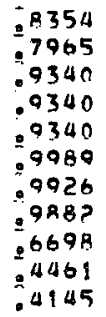 & $\begin{array}{l}727.1 \\
740.1 \\
665.8 \\
665.8 \\
665.8 \\
89.6 \\
528.1 \\
605.1 \\
811.2 \\
-34.6 \\
8.5 .6\end{array}$ & $\begin{array}{r}.4283 \\
.4339 \\
.1288 \\
.01168 \\
.4030 \\
.3343 \\
.3705 \\
.3639 \\
01108 \\
.0445 \\
4.5556\end{array}$ \\
\hline
\end{tabular}

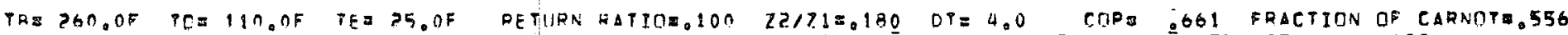

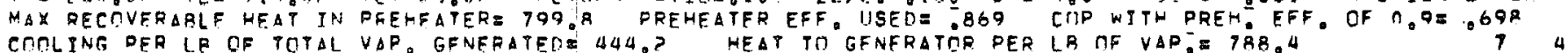

\begin{tabular}{|c|c|c|c|c|c|c|c|c|c|c|c|}
\hline LINE & TFMP & FRESS & CONC & ENTHALPY & MASS FLOK & LINE & TEMP & PRESS & CONE & ENTHALPY & MASS FLOW \\
\hline $\begin{array}{r}1 \\
2 \\
3 \\
4 \\
5 \\
6 \\
7 \\
8 \\
9 \\
11 \\
11\end{array}$ & $\begin{array}{l}110 \% 0 \\
21507 \\
22700 \\
23190 \\
120.0 \\
170.5 \\
240.3 \\
26000 \\
22790 \\
227.0 \\
262.8\end{array}$ & $\begin{array}{r}53: 5 \\
260: 9 \\
245: 9 \\
245 \% 9 \\
245: 9 \\
24599 \\
245: 9 \\
47=3 \\
53: 5 \\
88.5 \\
98.5\end{array}$ & $\begin{array}{l}.4145 \\
04145 \\
.3710 \\
.3599 \\
.8667 \\
.5460 \\
.3341 \\
.0749 \\
.1086 \\
.1828 \\
.4067\end{array}$ & $\begin{array}{r}-22.0 \\
95.0 \\
112.4 \\
118.4 \\
58.2 \\
-8.9 \\
132.5 \\
219.0 \\
167.0 \\
140.2 \\
206.3\end{array}$ & $\begin{array}{r}5.5556 \\
1.0000 \\
09548 \\
4.1209 \\
00406 \\
00709 \\
08684 \\
1.3627 \\
1.4407 \\
.9587 \\
09678\end{array}$ & $\begin{array}{l}12 \\
13 \\
14 \\
15 \\
16 \\
17 \\
18 \\
19 \\
20 \\
21 \\
22\end{array}$ & $\begin{array}{l}200.0 \\
23900 \\
23100 \\
23900 \\
23100 \\
120.0 \\
10900 \\
170.5 \\
221.0 \\
100.0 \\
215.7\end{array}$ & $\begin{array}{r}88.5 \\
88.5 \\
245.9 \\
245.9 \\
245.9 \\
245.9 \\
53.5 \\
24509 \\
53.5 \\
53.5 \\
260.9\end{array}$ & $\begin{array}{l}.6245 \\
.7894 \\
09319 \\
09319 \\
09319 \\
.9319 \\
09989 \\
09926 \\
.9879 \\
.6088 \\
.4461 \\
.4145\end{array}$ & $\begin{array}{l}846.4 \\
743.5 \\
667.8 \\
667.8 \\
667.8 \\
89.6 \\
598.1 \\
605.7 \\
901.2 \\
034.6 \\
95.6\end{array}$ & $\begin{array}{r}.4890 \\
.4723 \\
.0084 \\
.1316 \\
.0347 \\
.4466 \\
.4960 \\
.4872 \\
.0780 \\
.0619 \\
4.5556\end{array}$ \\
\hline
\end{tabular}




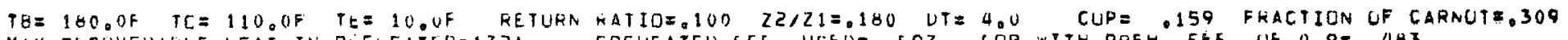

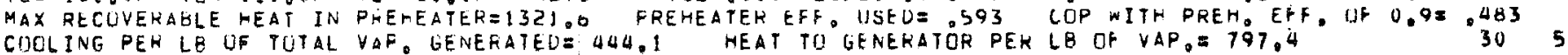

\begin{tabular}{|c|c|c|c|c|c|c|c|c|c|c|c|}
\hline LINE & $T E M P$ & PRESS & $\operatorname{CONL}$ & ENTHALPY & MASS FLOW & LINE & TEMP & PRESS & CONC & ENTHALPY & MASS FLOW \\
\hline $\begin{array}{r}1 \\
2 \\
3 \\
4 \\
5 \\
0 \\
7 \\
8 \\
9 \\
10 \\
11\end{array}$ & $\begin{array}{l}110.0 \\
235.9 \\
239.7 \\
243.4 \\
120.0 \\
170.8 \\
157.9 \\
130.0 \\
239.7 \\
239.7 \\
171.9\end{array}$ & $\begin{array}{r}34.3 \\
260.9 \\
245.9 \\
245.9 \\
245.9 \\
245.9 \\
245.9 \\
50.7 \\
34.3 \\
70.8 \\
70.8\end{array}$ & $\begin{array}{l}.3590 \\
.3546 \\
.3380 \\
.3280 \\
.8601 \\
.3236 \\
.5996 \\
.2095 \\
.0454 \\
.1204 \\
.2846\end{array}$ & $\begin{array}{r}-17.1 \\
124.0 \\
131.5 \\
137.6 \\
58.2 \\
-10.5 \\
39.8 \\
91.2 \\
197.0 \\
178.3 \\
64.6\end{array}$ & $\begin{array}{r}5.5556 \\
1.0000 \\
.4216 \\
4.3004 \\
.0223 \\
.0309 \\
1.7592 \\
1.1347 \\
.5616 \\
.3933 \\
.3807\end{array}$ & $\begin{array}{l}12 \\
13 \\
14 \\
15 \\
16 \\
17 \\
18 \\
19 \\
20 \\
21 \\
22\end{array}$ & $\begin{array}{l}180.0 \\
243.7 \\
243.7 \\
243.7 \\
243.7 \\
120.0 \\
100.0 \\
176.8 \\
239.7 \\
100.0 \\
235.9\end{array}$ & $\begin{array}{r}70.8 \\
70.8 \\
245.9 \\
245.9 \\
245.9 \\
245.9 \\
38.3 \\
245.9 \\
38.3 \\
38.3 \\
260.9\end{array}$ & $\begin{array}{l}.9209 \\
.6498 \\
.9130 \\
.9130 \\
.9130 \\
.9980 \\
.9873 \\
.9849 \\
.3703 \\
.3901 \\
.3596\end{array}$ & $\begin{array}{l}667.1 \\
828.0 \\
685.3 \\
685.3 \\
685.3 \\
89.0 \\
593.1 \\
611.2 \\
993.8 \\
-32.1 \\
124.0\end{array}$ & $\begin{array}{r}.2467 \\
.2533 \\
.7645 \\
0.7592 \\
.2442 \\
.1883 \\
.2184 \\
.2106 \\
.05731 \\
.0311 \\
4.5556\end{array}$ \\
\hline
\end{tabular}

$T B=220.0 F \quad T C=110.0 F \quad T E=10.0 F$ RETURN HATIO= $100 \quad Z 2 / 21=.180$ DT= 4.0 CUP= .289 FRACTIUN UF CARNUTI.380

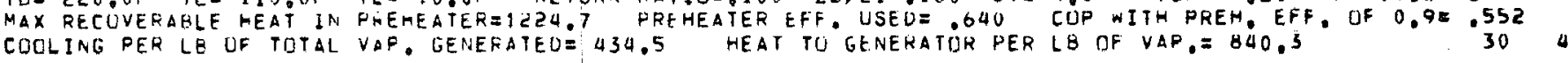

\begin{tabular}{|c|c|c|c|c|c|c|c|c|c|c|c|}
\hline LINE & TEMP & PRESS & CUNG & ENTHALFY & MASS FLUWW & LINE & TEMP & PRESS & CONC & ENTHALPY & MASS FLOW \\
\hline $\begin{array}{c}1 \\
2 \\
3 \\
3 \\
4 \\
5 \\
6 \\
7 \\
8 \\
9 \\
10 \\
11\end{array}$ & $\begin{array}{l}110.0 \\
235.9 \\
245.9 \\
248.1 \\
120.0 \\
179.9 \\
178.0 \\
2210.0 \\
245.9 \\
245.9 \\
194.2\end{array}$ & $\begin{array}{r}30.3 \\
260.9 \\
245.9 \\
245.9 \\
245.9 \\
245.9 \\
245.9 \\
50.7 \\
38.3 \\
70.8 \\
70.8\end{array}$ & $\begin{array}{l}.3590 \\
.3590 \\
.3224 \\
.3161 \\
.8001 \\
.5124 \\
.5195 \\
.1154 \\
.0341 \\
.1046 \\
.2271\end{array}$ & $\begin{array}{r}-17.1 \\
124.0 \\
141.0 \\
140.4 \\
58.2 \\
-11.1 \\
58.7 \\
158.7 \\
206.1 \\
187.9 \\
102.3\end{array}$ & $\begin{array}{r}5.5556 \\
1.0000 \\
.5737 \\
4.1905 \\
.0409 \\
.0720 \\
1.3830 \\
1.0846 \\
.7412 \\
.5200 \\
.5218\end{array}$ & $\begin{array}{l}12 \\
13 \\
14 \\
15 \\
16 \\
17 \\
18 \\
19 \\
20 \\
21 \\
22\end{array}$ & $\begin{array}{l}220.0 \\
249.9 \\
249.9 \\
249.9 \\
249.9 \\
120.0 \\
100.0 \\
179.9 \\
245.9 \\
100.0 \\
235.9\end{array}$ & $\begin{array}{r}70.8 \\
70.8 \\
245.9 \\
245.9 \\
245.9 \\
245.9 \\
38.3 \\
245.9 \\
38.3 \\
38.3 \\
200.9\end{array}$ & $\begin{array}{l}.7850 \\
.0048 \\
.9019 \\
.9019 \\
.9019 \\
.9989 \\
.9873 \\
.9832 \\
.2908 \\
.3901 \\
.3596\end{array}$ & $\begin{array}{r}739.3 \\
857.6 \\
69.4 .9 \\
694.9 \\
694.9 \\
89.6 \\
593.1 \\
613.9 \\
1035.3 \\
-32.1 \\
124.0\end{array}$ & $\begin{array}{r}.3544 \\
.3585 \\
.4659 \\
.3830 \\
.3338 \\
.3037 \\
.3570 \\
.3447 \\
.3434 \\
.0596 \\
4.5556\end{array}$ \\
\hline
\end{tabular}

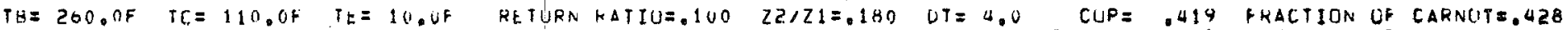

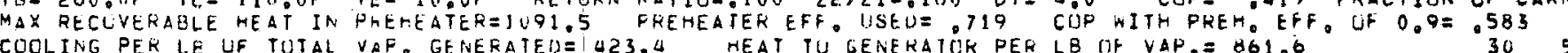

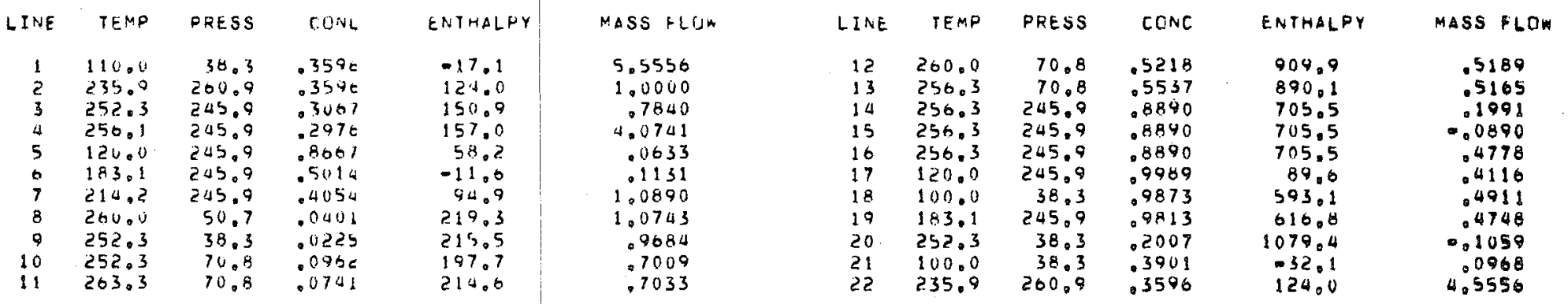




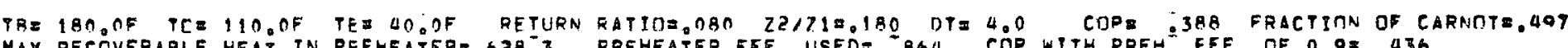

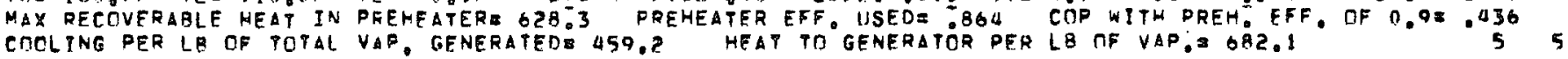

\begin{tabular}{|c|c|c|c|c|c|c|c|c|c|c|c|}
\hline LINE & $T E^{M P}$ & PRESS & CONE & ENTHALPY & MASS FLOW & LINE & TEMP & PRESS & CONE & ENTHALPY & MASS LOK \\
\hline $\begin{array}{l}1 \\
2 \\
5 \\
4 \\
5 \\
6 \\
9 \\
8 \\
9 \\
10 \\
19\end{array}$ & $\begin{array}{l}11000 \\
196.9 \\
272.9 \\
206.1 \\
120.0 \\
158.0 \\
16506 \\
180.0 \\
202.9 \\
20201 \\
191.5\end{array}$ & 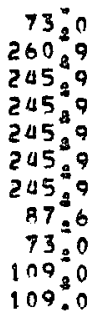 & $\begin{array}{l}.4715 \\
.4715 \\
.4414 \\
.4289 \\
08667 \\
.5983 \\
.5660 \\
.2993 \\
.2125 \\
.2799 \\
.3071\end{array}$ & $\begin{array}{r}-23.5 \\
74.2 \\
79.8 \\
84.4 \\
58.2 \\
-3.6 \\
44.8 \\
70.8 \\
114.5 \\
99.2 \\
82.2\end{array}$ & $\begin{array}{r}5.5556 \\
1.0000 \\
09072 \\
401004 \\
.0126 \\
00212 \\
102412 \\
1.4129 \\
1.2249 \\
.6823 \\
.6866\end{array}$ & $\begin{array}{l}12 \\
13 \\
14 \\
15 \\
16 \\
19 \\
18 \\
19 \\
20 \\
21 \\
22\end{array}$ & $\begin{array}{l}180.0 \\
206.1 \\
206.1 \\
206.1 \\
206.01 \\
120.0 \\
100.0 \\
150.0 \\
202.0 \\
100.0 \\
196.9\end{array}$ & $\begin{array}{r}109.0 \\
109.0 \\
245.9 \\
245.0 \\
245.9 \\
245.9 \\
73.0 \\
245.9 \\
73.0 \\
73.0 \\
260.9\end{array}$ & 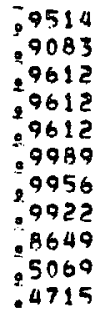 & $\begin{array}{l}644.2 \\
682.7 \\
639.9 \\
639.9 \\
630.0 \\
89.0 \\
583.3 \\
596.0 \\
705.0 \\
-33.6 \\
74.2\end{array}$ & $\begin{array}{r}.3689 \\
.3646 \\
.1460 \\
.2412 \\
.3652 \\
.2362 \\
.2510 \\
.2487 \\
.11880 \\
.0190 \\
4.5530\end{array}$ \\
\hline
\end{tabular}

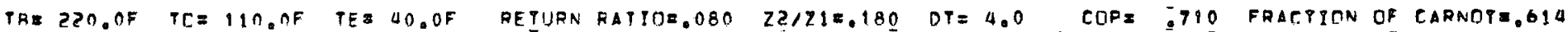

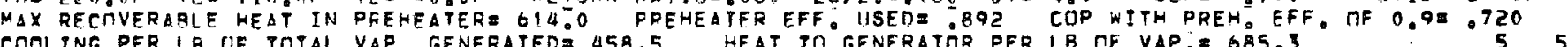

\begin{tabular}{|c|c|c|c|c|c|c|c|c|c|c|c|}
\hline LINF & TEMP & PRESS & CONE & ENTHALPY & MASS FLOW & LINE & TFMD & PRESS & cOne. & ENTHALPY & MASS FLO \\
\hline $\begin{array}{l}1 \\
2 \\
3 \\
0 \\
5 \\
6 \\
7 \\
8 \\
9 \\
10 \\
11\end{array}$ & $\begin{array}{l}110.0 \\
196.0 \\
202.6 \\
20696 \\
120.0 \\
158.3 \\
202.6 \\
220.0 \\
20206 \\
20206 \\
210.3\end{array}$ & 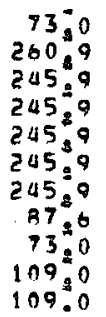 & $\begin{array}{l}.4715 \\
.4715 \\
.4398 \\
.4273 \\
.8667 \\
.5979 \\
.4390 \\
.1988 \\
.2112 \\
.2786 \\
.2509\end{array}$ & $\begin{array}{r}-23.5 \\
74.2 \\
80.4 \\
85.0 \\
58.2 \\
-3.7 \\
80.4 \\
137.6 \\
115.4 \\
100.1 \\
112.7\end{array}$ & $\begin{array}{r}5.5556 \\
1.0000 \\
.0425 \\
4.1779 \\
.0215 \\
.0365 \\
09370 \\
1.2504 \\
1.2734 \\
.7091 \\
.7083\end{array}$ & $\begin{array}{l}12 \\
13 \\
14 \\
15 \\
16 \\
17 \\
19 \\
19 \\
20 \\
21 \\
22\end{array}$ & $\begin{array}{l}220.0 \\
206.6 \\
206.6 \\
206.6 \\
206.6 \\
120.0 \\
109.0 \\
158.3 \\
196.6 \\
100.0 \\
196.0\end{array}$ & $\begin{array}{r}109.0 \\
109.0 \\
245.9 \\
245.9 \\
245.9 \\
245.9 \\
73.9 \\
245.9 \\
73.0 \\
73.0 \\
260.9\end{array}$ & 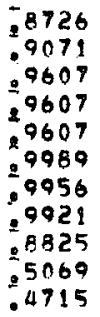 & $\begin{array}{l}708.5 \\
683.0 \\
640.5 \\
640.5 \\
640.5 \\
89.6 \\
583.3 \\
596.0 \\
694.0 \\
-33.0 \\
70.2\end{array}$ & $\begin{array}{r}.3775 \\
.3783 \\
.0183 \\
.0621 \\
.3777 \\
.4009 \\
.4254 \\
.4216 \\
.0230 \\
.0327 \\
4.5556\end{array}$ \\
\hline
\end{tabular}

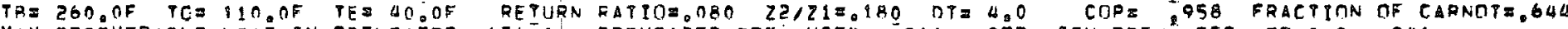

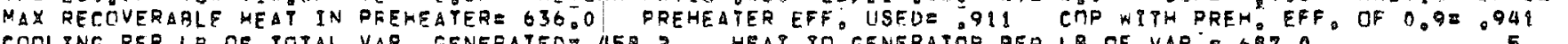

\begin{tabular}{|c|c|c|c|c|c|c|c|c|c|c|c|}
\hline LINE & TEMP & PRESS & CONC & ENPHALPY & MASS FLOW & LINE & PEMP & PRESS & CONC & FNYHALPY & MASS FLOW \\
\hline $\begin{array}{l}1 \\
2 \\
3 \\
4 \\
5 \\
6 \\
7 \\
8 \\
9 \\
10 \\
11\end{array}$ & $\begin{array}{l}11009 \\
10609 \\
20209 \\
20609 \\
120.0 \\
158.4 \\
25005 \\
26000 \\
20209 \\
20290 \\
245.7\end{array}$ & 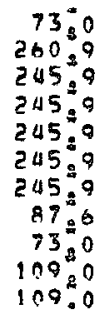 & $\begin{array}{l}.4715 \\
.4715 \\
.4389 \\
.4264 \\
.8667 \\
.5964 \\
.3109 \\
.1104 \\
.2104 \\
.2778 \\
.1760\end{array}$ & $\begin{array}{r}-23.5 \\
74.2 \\
80.7 \\
85.4 \\
59.2 \\
0308 \\
148.7 \\
202.4 \\
11509 \\
100.6 \\
171.2\end{array}$ & $\begin{array}{r}5.5550 \\
1.0000 \\
09620 \\
401707 \\
00279 \\
00475 \\
07527 \\
1.01325 \\
1.03012 \\
07245 \\
07340\end{array}$ & $\begin{array}{l}12 \\
13 \\
14 \\
15 \\
16 \\
19 \\
18 \\
19 \\
20 \\
21 \\
22\end{array}$ & $\begin{array}{l}260.0 \\
200.9 \\
206.9 \\
206.9 \\
206.9 \\
120.0 \\
100.0 \\
158.4 \\
19609 \\
100.0 \\
19609\end{array}$ & $\begin{array}{l}10900 \\
10900 \\
24509 \\
24509 \\
24509 \\
245.0 \\
7300 \\
24509 \\
7500 \\
7300 \\
260.9\end{array}$ & 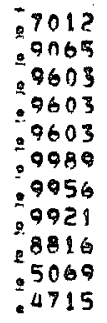 & $\begin{array}{l}709.6 \\
684.0 \\
640.8 \\
640.8 \\
640.8 \\
89.06 \\
593.3 \\
596.3 \\
695.5 \\
=33.6 \\
74.0\end{array}$ & $\begin{array}{r}.3066 \\
.3861 \\
0.0484 \\
.2473 \\
.3849 \\
.5154 \\
05481 \\
05433 \\
.1687 \\
0.0428 \\
4.5556\end{array}$ \\
\hline
\end{tabular}




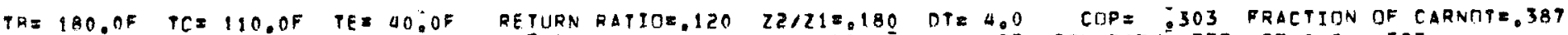
MAX RECOVERABLE HEAT IN PFBHEATER= 654.2 PREHEATER EFF, USED= .830 COP WITH PREH. FFF. DF O.9E .383

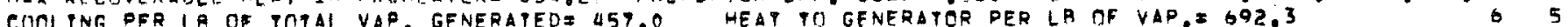

\begin{tabular}{|c|c|c|c|c|c|c|c|c|c|c|c|}
\hline LINE & TEMP & PRESS & cone & ENTHALPY & MASS FLOW & LINE & TEMP & PRESS & CONC & ENTHALPY & MASS FLOK \\
\hline $\begin{array}{r}1 \\
? \\
3 \\
11 \\
5 \\
6 \\
7 \\
2 \\
9 \\
10 \\
11\end{array}$ & $\begin{array}{l}110.0 \\
190.9 \\
203.9 \\
207.9 \\
120.0 \\
158.9 \\
156.9 \\
180.0 \\
203.9 \\
203.9 \\
196.9\end{array}$ & $\begin{array}{r}73: 0 \\
260: 9 \\
245: 9 \\
245: 9 \\
245: 9 \\
245: 9 \\
245: 9 \\
97: 6 \\
73: 0 \\
109: 0 \\
109.0\end{array}$ & $\begin{array}{l}.4715 \\
.4715 \\
.4359 \\
.4236 \\
.8667 \\
.5942 \\
.6038 \\
.2993 \\
.2081 \\
.2754 \\
.2934\end{array}$ & $\begin{array}{r}-23.5 \\
74.2 \\
81.8 \\
86.5 \\
58.2 \\
-4.1 \\
39.5 \\
70.8 \\
197.0 \\
102.2 \\
90.9\end{array}$ & $\begin{array}{r}5.5556 \\
1.0000 \\
.0783 \\
4.1477 \\
.0120 \\
.0206 \\
1.3724 \\
1.9953 \\
1.7155 \\
1.2450 \\
1.2500\end{array}$ & $\begin{array}{l}12 \\
13 \\
14 \\
15 \\
16 \\
17 \\
18 \\
10 \\
20 \\
21 \\
22\end{array}$ & $\begin{array}{l}180.0 \\
207.9 \\
207.0 \\
207.9 \\
207.9 \\
120.0 \\
100.0 \\
158.9 \\
203.9 \\
100.0 \\
196.0\end{array}$ & $\begin{array}{l}109.0 \\
109.0 \\
245.9 \\
245.9 \\
245.9 \\
245.9 \\
73.0 \\
245.9 \\
73.0 \\
73.0 \\
260.9\end{array}$ & $\begin{array}{l}.9514 \\
09043 \\
.9592 \\
.9592 \\
.9592 \\
.9989 \\
0956 \\
0920 \\
99586 \\
8586 \\
5069 \\
4715\end{array}$ & $\begin{array}{l}644.2 \\
685.8 \\
641.9 \\
641.9 \\
641.9 \\
89.6 \\
583.3 \\
596.7 \\
709.6 \\
-33.6 \\
70.2\end{array}$ & $\begin{array}{r}.4128 \\
.4078 \\
.2144 \\
.3724 \\
.4078 \\
.2172 \\
.2312 \\
.2292 \\
.02797 \\
.0186 \\
4.5556\end{array}$ \\
\hline
\end{tabular}

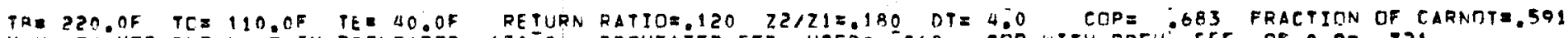

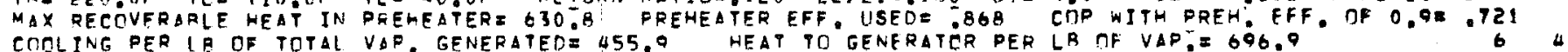

\begin{tabular}{|c|c|c|c|c|c|c|c|c|c|c|c|}
\hline LINE & TEMP & PRESS & rONC & ENTTHALPY & MASS FLOW & LINE & TFMP & PRESS & CONE & ENYHALPY & MASS FLOW \\
\hline $\begin{array}{l}1 \\
2 \\
3 \\
4 \\
5 \\
6 \\
7 \\
2 \\
0 \\
10 \\
11\end{array}$ & $\begin{array}{l}110.0 \\
19699 \\
204.8 \\
20892 \\
120 \% 0 \\
15904 \\
20303 \\
22000 \\
20408 \\
20408 \\
208.9\end{array}$ & $\begin{array}{r}73: 0 \\
260: 9 \\
245: 9 \\
245: 9 \\
205: 9 \\
245: 90 \\
245: 9 \\
87: 6 \\
73: 0 \\
109: 0 \\
109: 0\end{array}$ & $\begin{array}{l}.4715 \\
.4715 \\
.4332 \\
.4209 \\
.8667 \\
.9928 \\
.4370 \\
.1988 \\
.2059 \\
.2730 \\
.2631\end{array}$ & $\begin{array}{r}-23.5 \\
74.2 \\
82.9 \\
87.6 \\
58.2 \\
-4 . .3 \\
81.01 \\
137.6 \\
119.2 \\
103.7 \\
110.3\end{array}$ & $\begin{array}{r}5.5556 \\
1.0000 \\
.9300 \\
4.1264 \\
.0253 \\
.0437 \\
.9339 \\
1.7994 \\
1.8182 \\
1.3191 \\
1.3185\end{array}$ & $\begin{array}{l}12 \\
13 \\
14 \\
15 \\
16 \\
17 \\
18 \\
10 \\
20 \\
21 \\
22\end{array}$ & $\begin{array}{l}220.0 \\
208.8 \\
208.8 \\
208.8 \\
208.8 \\
120.0 \\
100.0 \\
150.4 \\
198.8 \\
100.0 \\
196.0\end{array}$ & $\begin{array}{r}109.0 \\
109.0 \\
245.0 \\
245.9 \\
245.9 \\
245.9 \\
73.0 \\
24509 \\
7300 \\
7300 \\
260.9\end{array}$ & 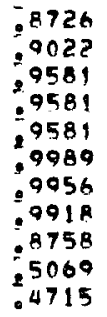 & $\begin{array}{l}708.5 \\
687.4 \\
642.9 \\
642.9 \\
642.9 \\
89.6 \\
583.3 \\
597.0 \\
699.2 \\
-33.6 \\
74.2\end{array}$ & $\begin{array}{l}.4304 \\
.4310 \\
.0226 \\
.0662 \\
.4291 \\
.4489 \\
.4783 \\
.4742 \\
.0168 \\
.0397 \\
4.5596\end{array}$ \\
\hline
\end{tabular}

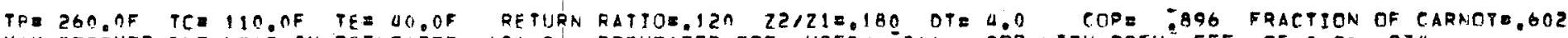

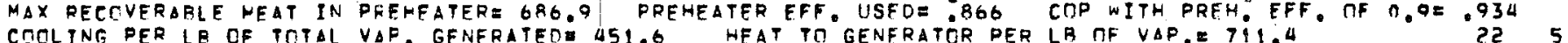

\begin{tabular}{|c|c|c|c|c|c|c|c|c|c|c|c|}
\hline INE & TEMP & PRESS & CONG & ENTHALPY & MASS FLOW & LINE & TFMP & PRESS & CONE & ENTHALPY & MASS FLOW \\
\hline $\begin{array}{r}1 \\
? \\
3 \\
4 \\
5 \\
6 \\
7 \\
8 \\
0 \\
10 \\
11\end{array}$ & $\begin{array}{l}110.9 \\
106.9 \\
208.1 \\
212.9 \\
120.0 \\
161.1 \\
250.0 \\
260.0 \\
208.1 \\
208.1 \\
232.4\end{array}$ & $\begin{array}{r}73: 0 \\
260: 9 \\
245: 9 \\
245: 9 \\
245: 9 \\
245: 9 \\
245: 9 \\
97: 6 \\
73=0 \\
109: 0 \\
1090\end{array}$ & $\begin{array}{l}.4715 \\
.4715 \\
.4233 \\
.41114 \\
.8667 \\
.5849 \\
.3123 \\
.1104 \\
.1975 \\
.2646 \\
.2063\end{array}$ & $\begin{array}{r}-23.5 \\
74.2 \\
86.8 \\
91.0 \\
52.2 \\
-5.2 \\
147.0 \\
202.4 \\
125.0 \\
109.1 \\
149.3\end{array}$ & $\begin{array}{r}5.5556 \\
1.0000 \\
.0451 \\
4.0502 \\
.0002 \\
.0710 \\
.7519 \\
1.0382 \\
1.0519 \\
1.3425 \\
1.3542\end{array}$ & $\begin{array}{l}12 \\
13 \\
14 \\
15 \\
16 \\
17 \\
18 \\
19 \\
20 \\
21 \\
2 ?\end{array}$ & $\begin{array}{l}260.0 \\
2120.1 \\
212.1 \\
212.1 \\
2120.1 \\
120.0 \\
100.0 \\
161.01 \\
202.1 \\
100.0 \\
196.9\end{array}$ & $\begin{array}{r}109.0 \\
109.0 \\
245.9 \\
245.0 \\
245.0 \\
245.9 \\
73.0 \\
245.0 \\
73.0 \\
73.0 \\
260.9\end{array}$ & $\begin{array}{l}.7012 \\
8941 \\
99540 \\
99540 \\
99540 \\
09880 \\
.9956 \\
9913 \\
9013 \\
8648 \\
.5069 \\
.4715\end{array}$ & $\begin{array}{r}799.6 \\
693.5 \\
646.0 \\
646.6 \\
646.6 \\
89.6 \\
583.3 \\
598.2 \\
706.0 \\
-33.6 \\
74.2\end{array}$ & $\begin{array}{l}.4475 \\
.4359 \\
.0204 \\
.2481 \\
.5040 \\
.6623 \\
.7077 \\
.7024 \\
.2136 \\
.0658 \\
0.5556\end{array}$ \\
\hline
\end{tabular}




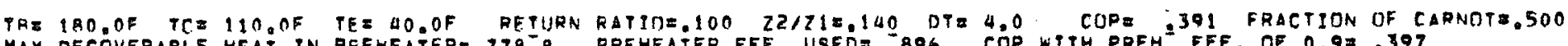

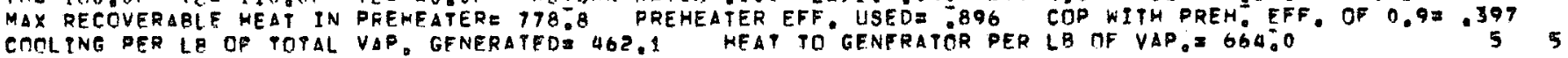

\begin{tabular}{|c|c|c|c|c|c|c|c|c|c|c|c|}
\hline INE & TEMP & FPESS & eONE & ENTHALPY & MASS FLOW & L.INE & TEMP & PRESS & CONE & ENPHALPY & MASS FLOK \\
\hline $\begin{array}{r}1 \\
2 \\
3 \\
4 \\
5 \\
6 \\
7 \\
8 \\
0 \\
110 \\
11\end{array}$ & $\begin{array}{l}110.0 \\
196.9 \\
199.5 \\
203.5 \\
120.0 \\
156.8 \\
163.5 \\
180.0 \\
199.5 \\
199.5 \\
102.3\end{array}$ & $\begin{array}{r}73: 0 \\
260: 9 \\
245: 9 \\
245: 9 \\
245: 9 \\
245: 9 \\
245: 9 \\
87: 0 \\
73: 0 \\
109: 0 \\
109: 0\end{array}$ & $\begin{array}{l}.4719 \\
.4795 \\
.4499 \\
.4364 \\
.8667 \\
.6045 \\
.5752 \\
.2993 \\
.2189 \\
.2865 \\
.3051\end{array}$ & $\begin{array}{r}-23.5 \\
74.2 \\
76.0 \\
81.0 \\
58.2 \\
-2.6 \\
43.3 \\
70.8 \\
110.1 \\
95.9 \\
83.5\end{array}$ & $\begin{array}{r}7.1429 \\
1.0000 \\
09199 \\
5.7341 \\
0.0118 \\
00209 \\
1.2667 \\
1.6901 \\
1.4822 \\
.9608 \\
.9653\end{array}$ & $\begin{array}{l}12 \\
13 \\
14 \\
15 \\
16 \\
17 \\
18 \\
19 \\
20 \\
21 \\
22\end{array}$ & $\begin{array}{l}180.0 \\
203.5 \\
203.5 \\
203.5 \\
203.5 \\
120.0 \\
100.0 \\
156.8 \\
199.5 \\
100.0 \\
196.0\end{array}$ & $\begin{array}{l}109.0 \\
10900 \\
245.9 \\
245.9 \\
245.9 \\
24509 \\
7300 \\
245.9 \\
73.0 \\
73.0 \\
260.9\end{array}$ & $\begin{array}{l}9514 \\
29139 \\
29649 \\
99641 \\
2944 \\
9641 \\
9989 \\
9956 \\
9929 \\
99334 \\
873069 \\
25069 \\
4715\end{array}$ & $\begin{array}{l}644.2 \\
678.0 \\
637.2 \\
637.2 \\
637.2 \\
89.6 \\
583.3 \\
505.1 \\
710.7 \\
033.6 \\
74.2\end{array}$ & $\begin{array}{r}.4030 \\
.3985 \\
.1388 \\
.2667 \\
.4089 \\
.2484 \\
.2630 \\
.2602 \\
.02079 \\
.0181 \\
6.1429\end{array}$ \\
\hline
\end{tabular}

TRE $220.0 F$ TCE $110.0 F$ TE $40.0 F$ RETURN RATIOE.100 Z2/Z1=.140 DTE 4.0 COP= Z762 FRACTIDN OF CARNOTE.659 MAZ RECOVERABLE HEAT IN PRERFATERE 766.2 PREHEATER EFF. USEDZ 922 TTP WITH PRFH. EFF. DF O.9 .723

\begin{tabular}{|c|c|c|c|c|c|c|c|c|c|c|c|}
\hline LINE & TEMP & PRESS & CONE & ENTHALPY & MASS FLOW & LINE & TEMP & PRESS & CONE & ENTHALPY & MASS FLOW \\
\hline $\begin{array}{r}1 \\
? \\
3 \\
4 \\
5 \\
6 \\
7 \\
2 \\
9 \\
19 \\
19\end{array}$ & 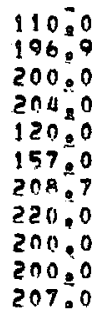 & 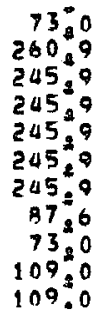 & $\begin{array}{l}.4715 \\
.4715 \\
.4477 \\
.4350 \\
.8667 \\
.6033 \\
.4211 \\
.1988 \\
.2176 \\
.2853 \\
.2678\end{array}$ & $\begin{array}{r}-23.5 \\
74.2 \\
77.4 \\
82.0 \\
58.2 \\
-2.8 \\
87.5 \\
137.0 \\
110.9 \\
95.8 \\
107.2\end{array}$ & $\begin{array}{r}7.1020 \\
1.0000 \\
.9598 \\
5.7185 \\
.0214 \\
.0381 \\
.9072 \\
1.5054 \\
1.5473 \\
1.0028 \\
1.0015\end{array}$ & $\begin{array}{l}12 \\
13 \\
14 \\
15 \\
16 \\
17 \\
18 \\
19 \\
20 \\
21 \\
22\end{array}$ & $\begin{array}{l}220.0 \\
204.0 \\
204.0 \\
204.0 \\
204.0 \\
120.0 \\
100.0 \\
157.0 \\
194.0 \\
100.0 \\
196.0\end{array}$ & $\begin{array}{r}109.0 \\
109.0 \\
245.9 \\
245.9 \\
245.9 \\
245.9 \\
73.0 \\
245.9 \\
73.0 \\
73.0 \\
260.9\end{array}$ & $\begin{array}{l}9726 \\
9127 \\
29635 \\
29635 \\
90635 \\
9989 \\
9996 \\
9956 \\
9928 \\
.8902 \\
5069 \\
.4715\end{array}$ & $\begin{array}{l}708.5 \\
679.2 \\
637.9 \\
637.7 \\
637.7 \\
89.6 \\
583.3 \\
595.3 \\
689.9 \\
-33.6 \\
74.2\end{array}$ & $\begin{array}{r}.4139 \\
.4153 \\
.0106 \\
.0928 \\
.4244 \\
.4490 \\
.0734 \\
.4684 \\
.0420 \\
.0332 \\
6.1429\end{array}$ \\
\hline
\end{tabular}

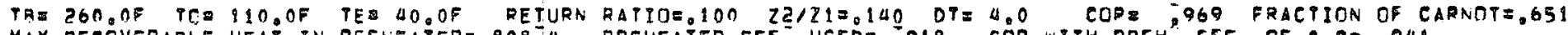

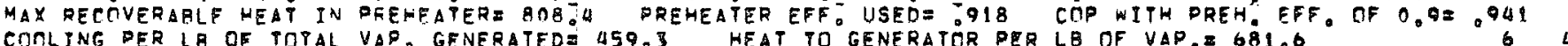

\begin{tabular}{|c|c|c|c|c|c|c|c|c|c|c|c|}
\hline LINE & TEMD & PRESS & CONC & ENTHALPY & MASS FLOW & LINE & TEMP & PRESS & CONC & ENTHALPY & MASS FLOW \\
\hline $\begin{array}{l}1 \\
2 \\
3 \\
4 \\
5 \\
6 \\
7 \\
5 \\
9 \\
10 \\
11\end{array}$ & $\begin{array}{l}11000 \\
190 \% 9 \\
20200 \\
20600 \\
120.0 \\
15800 \\
25090 \\
26000 \\
20200 \\
20200 \\
23508\end{array}$ & $\begin{array}{r}73 \% 0 \\
260 \% 9 \\
245 \% 9 \\
245 \% 9 \\
245 \% 9 \\
245 \% 9 \\
24589 \\
9796 \\
73 \% 0 \\
109 \% \\
109 \%\end{array}$ & $\begin{array}{l}.4715 \\
04715 \\
0496 \\
04290 \\
08697 \\
.5985 \\
09123 \\
01104 \\
02129 \\
.2802 \\
.2000\end{array}$ & $\begin{array}{r}-23.5 \\
74.2 \\
79.8 \\
84.3 \\
58.2 \\
-3.08 \\
147.4 \\
202.4 \\
114.4 \\
99.9 \\
153.4\end{array}$ & $\begin{array}{l}701429 \\
100000 \\
09733 \\
506534 \\
00336 \\
00568 \\
0.8547 \\
1.3649 \\
105927 \\
1.0984 \\
1.0287\end{array}$ & $\begin{array}{l}12 \\
13 \\
14 \\
15 \\
16 \\
17 \\
18 \\
19 \\
20 \\
21 \\
22\end{array}$ & $\begin{array}{l}260.0 \\
206.0 \\
206.0 \\
206.0 \\
20600 \\
120.0 \\
100.0 \\
95800 \\
196.0 \\
100.0 \\
196.0\end{array}$ & $\begin{array}{r}109.0 \\
10900 \\
24500 \\
24509 \\
245.0 \\
245.9 \\
73.0 \\
24509 \\
73.0 \\
7300 \\
26009\end{array}$ & 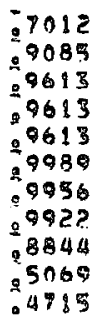 & $\begin{array}{l}709.6 \\
682.5 \\
639.8 \\
639.8 \\
639.0 \\
89.6 \\
533.3 \\
596.0 \\
693.9 \\
033.0 \\
74.2\end{array}$ & $\begin{array}{r}.4293 \\
04190 \\
0.0108 \\
02453 \\
04901 \\
.6341 \\
06739 \\
06678 \\
02078 \\
.0507 \\
6.1429\end{array}$ \\
\hline
\end{tabular}




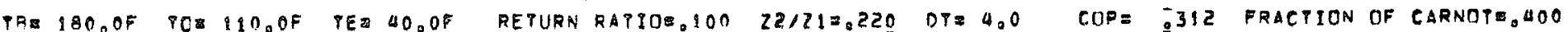
MAZ RECOVERABLE HEAT IN PFEMEATERE 555:9 PREMEATER EFF. USEOZ TO9 COP WITH PREHOEFF. DF O.9F .4I3

\begin{tabular}{|c|c|c|c|c|c|c|c|c|c|c|c|}
\hline LINE & TEMP & PRESS & CONC & ENPMALPY & MASS FLOW & LINE & TEMP & PRESS & CONC & ENTHALPY & MASS FLOW \\
\hline $\begin{array}{l}1 \\
2 \\
3 \\
4 \\
5 \\
6 \\
7 \\
8 \\
9 \\
10 \\
11\end{array}$ & $\begin{array}{l}11090 \\
19099 \\
206.5 \\
210.5 \\
120.0 \\
160.2 \\
199.5 \\
180.0 \\
206.5 \\
200.5 \\
196.9\end{array}$ & $\begin{array}{r}7380 \\
26089 \\
24589 \\
24589 \\
24589 \\
24589 \\
24599 \\
9790 \\
7390 \\
10980 \\
109.0\end{array}$ & $\begin{array}{l}.4719 \\
04715 \\
04282 \\
04960 \\
08687 \\
.5885 \\
.3918 \\
.2993 \\
.2018 \\
.2688 \\
.2938\end{array}$ & $\begin{array}{r}23.5 \\
74.0 \\
84.0 \\
89.6 \\
58.2 \\
04.8 \\
40.7 \\
70.8 \\
122.0 \\
106.4 \\
90.5\end{array}$ & $\begin{array}{r}4.5455 \\
1.0000 \\
08674 \\
3.01813 \\
00125 \\
00218 \\
1.3304 \\
1.0575 \\
1.4078 \\
09101 \\
09148\end{array}$ & $\begin{array}{l}12 \\
13 \\
14 \\
15 \\
16 \\
17 \\
18 \\
19 \\
20 \\
21 \\
22\end{array}$ & $\begin{array}{l}180.0 \\
21005 \\
210.5 \\
210.5 \\
210.5 \\
120.0 \\
100.0 \\
160.2 \\
206.5 \\
100.0 \\
196.9\end{array}$ & $\begin{array}{r}109.0 \\
10900 \\
24509 \\
24509 \\
245.9 \\
245.9 \\
73.0 \\
24509 \\
73.0 \\
73.0 \\
260.9\end{array}$ & 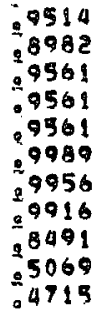 & $\begin{array}{r}644.2 \\
690.5 \\
644.7 \\
644.7 \\
644.7 \\
99.6 \\
593.3 \\
597.6 \\
715.1 \\
-33.6 \\
94.2\end{array}$ & $\begin{array}{r}.3743 \\
.3698 \\
.2131 \\
.3304 \\
.3641 \\
.2128 \\
02271 \\
.2253 \\
0.2499 \\
0.0200 \\
3.5435\end{array}$ \\
\hline
\end{tabular}

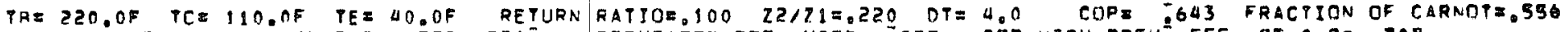
MAX RECOVERAELE HEAT IN PFEHEATERE $531 \% 0$ PREHEATER EFF. USED= 837 COP WITH PREH: EFF. OF O.93 707

\begin{tabular}{|c|c|c|c|c|c|c|c|c|c|c|c|}
\hline LINE & PEMD & PRESS & CONC & ENTHALPY & MASS FLOW & LINE & TEMD & PRESS & CONE & ENTHALPY & MASS PLOW \\
\hline $\begin{array}{r}1 \\
2 \\
3 \\
4 \\
5 \\
6 \\
7 \\
8 \\
9 \\
10 \\
11\end{array}$ & 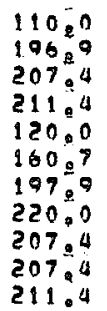 & 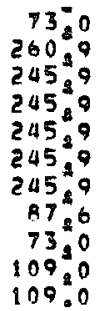 & $\begin{array}{l}.4715 \\
.4715 \\
.4253 \\
.4132 \\
.8667 \\
.5863 \\
.4536 \\
.1988 \\
.1993 \\
.2663 \\
.2568\end{array}$ & $\begin{array}{r}-23.5 \\
70.2 \\
86.0 \\
90.0 \\
58.2 \\
-5.0 \\
75.0 \\
137.6 \\
123.7 \\
108.0 \\
114.5\end{array}$ & $\begin{array}{r}9.5455 \\
1.0000 \\
.9129 \\
3.1640 \\
.0241 \\
.0424 \\
.9642 \\
1.4817 \\
1.4828 \\
.9583 \\
.9581\end{array}$ & $\begin{array}{l}12 \\
13 \\
14 \\
15 \\
16 \\
17 \\
18 \\
19 \\
20 \\
21 \\
22\end{array}$ & $\begin{array}{l}220.0 \\
211.4 \\
2111.4 \\
2111.4 \\
2110.4 \\
120.0 \\
100.0 \\
160.9 \\
201.4 \\
100.0 \\
196.9\end{array}$ & $\begin{array}{r}109.0 \\
109.0 \\
245.0 \\
24500 \\
245.0 \\
245.9 \\
73.0 \\
245.0 \\
7300 \\
7300 \\
260.0\end{array}$ & 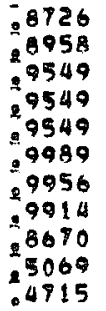 & $\begin{array}{l}708.5 \\
692.8 \\
645.8 \\
643.8 \\
645.8 \\
89.6 \\
583.3 \\
598.0 \\
704.0 \\
-33.6 \\
74.2\end{array}$ & $\begin{array}{r}.3882 \\
.3884 \\
.0523 \\
.0338 \\
.3819 \\
.4031 \\
.4305 \\
.4272 \\
.0011 \\
.0391 \\
.0453\end{array}$ \\
\hline
\end{tabular}

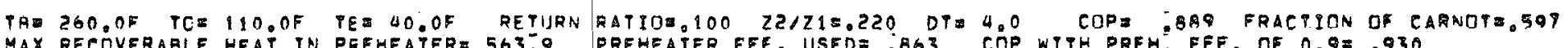

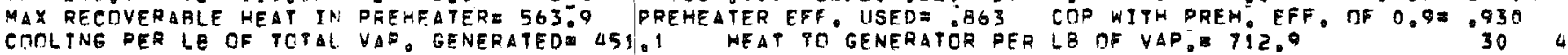

\begin{tabular}{|c|c|c|c|c|c|c|c|c|c|c|c|}
\hline LINE & TEMP & PRESS & rONE & ENTHALPY & MASS FLOW & LINE & TEMP & PRESS & CONE & ENTHALPY & MASS FLOW \\
\hline $\begin{array}{r}1 \\
2 \\
3 \\
4 \\
5 \\
6 \\
7 \\
9 \\
9 \\
10 \\
11\end{array}$ & $\begin{array}{l}110.0 \\
196.9 \\
208.5 \\
212.5 \\
120.0 \\
161.3 \\
250.0 \\
260.0 \\
208.5 \\
208.5 \\
238.7\end{array}$ & 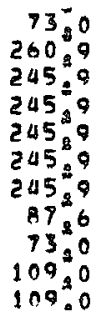 & $\begin{array}{l}.4715 \\
.4715 \\
.4221 \\
.4102 \\
.0667 \\
.5840 \\
.3123 \\
.1104 \\
1964 \\
.2636 \\
.1917\end{array}$ & $\begin{array}{r}-23.5 \\
74.2 \\
87.3 \\
92.1 \\
58.2 \\
-5.3 \\
147.4 \\
202.4 \\
125.7 \\
109.8 \\
159.8\end{array}$ & $\begin{array}{r}45455 \\
10000 \\
09365 \\
3.1451 \\
0.0333 \\
.0591 \\
.7517 \\
1.3477 \\
1.5212 \\
.9831 \\
.9943\end{array}$ & $\begin{array}{l}12 \\
13 \\
14 \\
15 \\
16 \\
17 \\
19 \\
19 \\
20 \\
21 \\
27\end{array}$ & $\begin{array}{l}260.0 \\
212.5 \\
212.5 \\
212.5 \\
212.5 \\
120.0 \\
100.0 \\
161.3 \\
202.5 \\
100.0 \\
196.9\end{array}$ & $\begin{array}{r}109.0 \\
109.0 \\
24509 \\
245.0 \\
24509 \\
245.0 \\
73.0 \\
245.0 \\
73.0 \\
73.0 \\
260.0\end{array}$ & 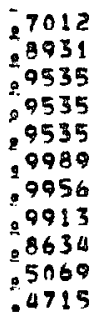 & $\begin{array}{r}799.6 \\
694.2 \\
647.0 \\
647.0 \\
649.0 \\
89.6 \\
583.3 \\
598.4 \\
706.8 \\
-33.6 \\
74.2\end{array}$ & $\begin{array}{r}.4098 \\
.3984 \\
.0113 \\
.2483 \\
.4001 \\
.5447 \\
.5823 \\
.5781 \\
.1736 \\
.0548 \\
3.5455\end{array}$ \\
\hline
\end{tabular}




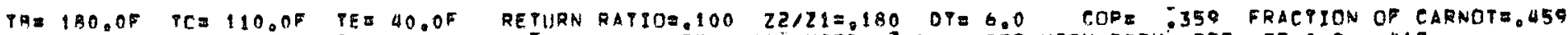

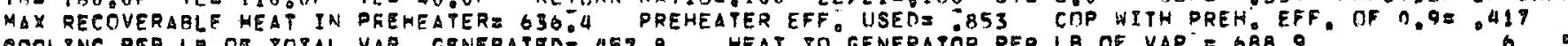

\begin{tabular}{|c|c|c|c|c|c|c|c|c|c|c|}
\hline TEMP & PRESS & $\operatorname{con} C$ & ENTHALPY & MASS FLOW & LINE & TEMP & PRESS & CONE & ENTHALPY & MASS FLO \\
\hline $\begin{array}{l}110.0 \\
196.0 \\
201.2 \\
20722 \\
120.0 \\
158.6 \\
162.6 \\
180.0 \\
201.2 \\
201.2 \\
192.6\end{array}$ & 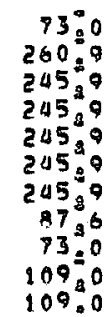 & $\begin{array}{l}.4715 \\
.4715 \\
.4439 \\
.4254 \\
.8667 \\
.5957 \\
.5787 \\
.2993 \\
.2145 \\
.2921 \\
.3044\end{array}$ & $\begin{array}{r}023.5 \\
74.2 \\
78.8 \\
85.7 \\
58.2 \\
93.9 \\
42.7 \\
70.8 \\
113.9 \\
97.9 \\
83.9\end{array}$ & $\begin{array}{r}5.5556 \\
1.0000 \\
.9076 \\
4.1627 \\
.0127 \\
.0217 \\
1.2812 \\
1.6793 \\
1.4614 \\
.9476 \\
.9525\end{array}$ & $\begin{array}{l}12 \\
13 \\
14 \\
15 \\
16 \\
17 \\
18 \\
19 \\
20 \\
21 \\
22\end{array}$ & $\begin{array}{l}180.0 \\
207.2 \\
209.2 \\
207.2 \\
207.2 \\
120.0 \\
100.0 \\
158.0 \\
201.2 \\
100.0 \\
106.9\end{array}$ & $\begin{array}{r}109.0 \\
109.0 \\
245.9 \\
245.9 \\
245.9 \\
245.9 \\
73.0 \\
24509 \\
7300 \\
7300 \\
26009\end{array}$ & 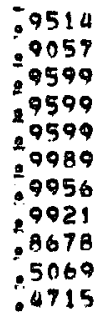 & $\begin{array}{l}644.2 \\
654.7 \\
641.2 \\
641.2 \\
641.2 \\
89.6 \\
583.0 \\
506.4 \\
704.2 \\
-33.6 \\
74.2\end{array}$ & $\begin{array}{r}.3987 \\
.3938 \\
.1597 \\
0.2812 \\
.3928 \\
.2330 \\
.2470 \\
.2457 \\
0.2179 \\
.0195 \\
4.5556\end{array}$ \\
\hline
\end{tabular}

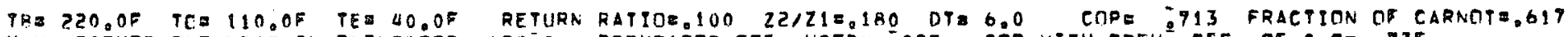

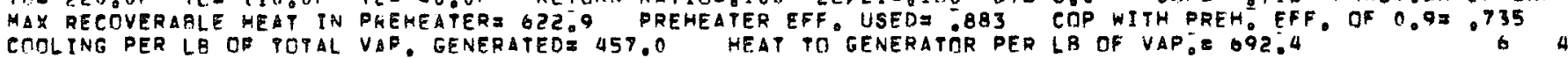

\begin{tabular}{|c|c|c|c|c|c|c|c|c|c|c|c|}
\hline LINE & TEMP & PRESS & CONE & ENTHALPY & MASS FLOW & LINE & TEMP & PRESS & CONC & ENTHALPY & MASS BLOK \\
\hline $\begin{array}{r}9 \\
2 \\
3 \\
4 \\
5 \\
6 \\
7 \\
8 \\
9 \\
10 \\
11\end{array}$ & $\begin{array}{l}11000 \\
19699 \\
20199 \\
2079 \\
12090 \\
1599 \\
20597 \\
22090 \\
20190 \\
20199 \\
207.4\end{array}$ & 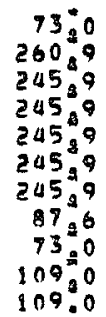 & $\begin{array}{l}.4719 \\
04795 \\
04499 \\
04239 \\
08667 \\
05942 \\
.4940 \\
.4300 \\
.1992 \\
.2129 \\
.2804 \\
.2608\end{array}$ & $\begin{array}{r}-23.5 \\
74.2 \\
79.6 \\
86.5 \\
58.2 \\
-4.1 \\
83.9 \\
137.6 \\
114.2 \\
98.9 \\
107.8\end{array}$ & $\begin{array}{r}5.5556 \\
1.0000 \\
.9477 \\
4.1474 \\
0.0237 \\
80006 \\
.9218 \\
1.4955 \\
1.5271 \\
.9899 \\
.9891\end{array}$ & $\begin{array}{l}12 \\
13 \\
14 \\
15 \\
16 \\
17 \\
18 \\
19 \\
20 \\
21 \\
22\end{array}$ & $\begin{array}{l}220.0 \\
207.9 \\
207.9 \\
207 \% 9 \\
207.9 \\
120.0 \\
100.0 \\
158.9 \\
107.9 \\
100.0 \\
196.9\end{array}$ & $\begin{array}{r}109.0 \\
10900 \\
245.9 \\
245.9 \\
245.9 \\
24509 \\
73.0 \\
245.9 \\
73.0 \\
73.0 \\
26009\end{array}$ & $\begin{array}{l}9726 \\
09042 \\
90592 \\
29592 \\
9592 \\
9592 \\
9989 \\
0995 \\
9920 \\
08786 \\
05060 \\
04915\end{array}$ & $\begin{array}{l}7178.5 \\
685.9 \\
641.9 \\
641.9 \\
641.9 \\
89.6 \\
583.3 \\
590.7 \\
697.5 \\
933.6 \\
74.2\end{array}$ & $\begin{array}{l}.4098 \\
.4106 \\
.0055 \\
.0784 \\
.4082 \\
.4279 \\
.4534 \\
.4515 \\
.0316 \\
.0367 \\
4.9596\end{array}$ \\
\hline
\end{tabular}

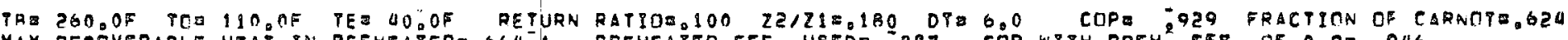

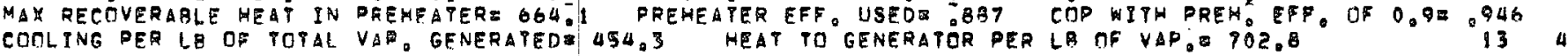

\begin{tabular}{|c|c|c|c|c|c|c|c|c|c|c|c|}
\hline LINE & TEMD & PRESS & COAC & ENTHALPY & MASS FLOW & LINE & TEMP & PRESS & CONC & ENPHALPY & MASS PLOH \\
\hline $\begin{array}{r}1 \\
2 \\
3 \\
4 \\
5 \\
6 \\
7 \\
9 \\
9 \\
10 \\
1 !\end{array}$ & $\begin{array}{l}11000 \\
190.9 \\
204.0 \\
210.0 \\
120.0 \\
160.0 \\
290.0 \\
260.0 \\
204.0 \\
204.0 \\
235.0\end{array}$ & 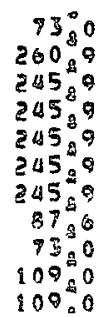 & $\begin{array}{l}.4719 \\
04795 \\
04354 \\
04972 \\
28667 \\
.5894 \\
03123 \\
01194 \\
02077 \\
.2749 \\
.9987\end{array}$ & $\begin{array}{r}-23.5 \\
74.2 \\
82.00 \\
89.1 \\
58.2 \\
04.8 \\
147.4 \\
202.0 \\
11709 \\
102.5 \\
154.8\end{array}$ & $\begin{array}{r}5.5550 \\
1.0000 \\
09031 \\
9.0073 \\
00547 \\
00605 \\
97529 \\
903587 \\
1.05555 \\
1.00074 \\
1.00182\end{array}$ & $\begin{array}{l}12 \\
13 \\
14 \\
15 \\
16 \\
18 \\
18 \\
18 \\
20 \\
29 \\
22\end{array}$ & $\begin{array}{l}260.0 \\
210.0 \\
210.0 \\
21000 \\
210.0 \\
120.0 \\
10000 \\
160.0 \\
20000 \\
10000 \\
19600\end{array}$ & $\begin{array}{r}409.0 \\
109.0 \\
24509 \\
24509 \\
24509 \\
24509 \\
73.0 \\
24500 \\
7500 \\
7300 \\
20000\end{array}$ & $\begin{array}{l}27012 \\
29992 \\
29960 \\
2906 \\
29560 \\
39989 \\
29956 \\
29916 \\
98719 \\
25069 \\
4915\end{array}$ & $\begin{array}{l}799.6 \\
689.7 \\
64403 \\
64403 \\
644.5 \\
89.6 \\
58303 \\
597.5 \\
70108 \\
033.0 \\
9402\end{array}$ & $\begin{array}{r}.4290 \\
04152 \\
0.0116 \\
.2491 \\
.4980 \\
.5988 \\
.6387 \\
.6335 \\
01989 \\
.0554 \\
4.5556\end{array}$ \\
\hline
\end{tabular}




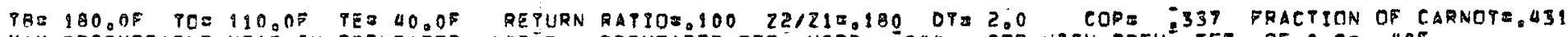

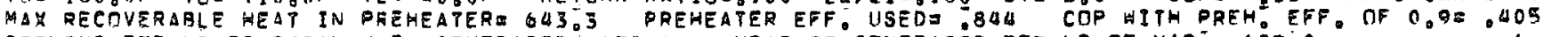
COOLYNG PER LQ OF POTAL VAP. GENERATEDE 459.6 HEAP PO GEAERAPOR PER LR OF YAP:= 685.0

\begin{tabular}{|c|c|c|c|c|c|c|c|c|c|c|c|}
\hline LINE & TEMP & PRESS & CONC & ENTHALPY & MASS FLOW & LINE & TEMP & PRESS & CONE & ENTHALPY & MASS F LOH \\
\hline $\begin{array}{r}1 \\
2 \\
3 \\
4 \\
5 \\
6 \\
7 \\
9 \\
9 \\
10 \\
11\end{array}$ & $\begin{array}{l}11090 \\
190.9 \\
20495 \\
200.5 \\
120.0 \\
158.3 \\
160.03 \\
180.00 \\
20495 \\
204.5 \\
190.4\end{array}$ & 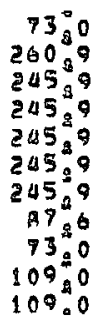 & $\begin{array}{l}.4799 \\
.4715 \\
.4339 \\
.4274 \\
.4274 \\
08697 \\
.5993 \\
.5889 \\
.2993 \\
.2064 \\
.2737 \\
.2947\end{array}$ & $\begin{array}{r}023.5 \\
74.02 \\
82.0 \\
84.0 \\
58.2 \\
-3.9 \\
41.2 \\
70.8 \\
118.9 \\
103.3 \\
90.0\end{array}$ & $\begin{array}{r}5.5556 \\
1.0000 \\
08813 \\
4.1701 \\
.0120 \\
.0204 \\
1.3145 \\
1.0704 \\
1.4317 \\
.9252 \\
.9296\end{array}$ & $\begin{array}{l}12 \\
13 \\
14 \\
15 \\
10 \\
17 \\
18 \\
19 \\
20 \\
29 \\
22\end{array}$ & $\begin{array}{l}180.0 \\
200.5 \\
200.5 \\
206.5 \\
206.5 \\
120.0 \\
100.0 \\
158.3 \\
204.5 \\
100.0 \\
196.9\end{array}$ & $\begin{array}{r}109.0 \\
109.0 \\
24509 \\
249.9 \\
245.9 \\
245.9 \\
73.0 \\
245.9 \\
7300 \\
73 \% 0 \\
260.9\end{array}$ & $\begin{array}{l}29314 \\
29072 \\
99607 \\
99609 \\
9909 \\
9607 \\
29989 \\
99956 \\
9922 \\
98962 \\
25069 \\
4415\end{array}$ & $\begin{array}{l}644.2 \\
683.5 \\
640.5 \\
640.5 \\
640.5 \\
89.8 \\
583.3 \\
396.2 \\
919.0 \\
033.8 \\
74.2\end{array}$ & $\begin{array}{r}.3992 \\
.3948 \\
.1945 \\
.03145 \\
.3765 \\
.2240 \\
.2381 \\
.2360 \\
.02387 \\
.0183 \\
4.5550\end{array}$ \\
\hline
\end{tabular}

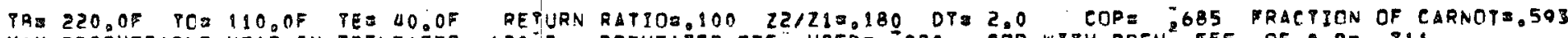

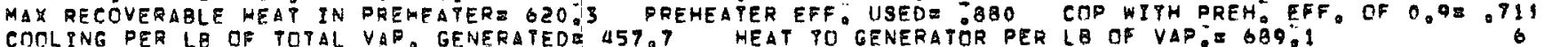

\begin{tabular}{|c|c|c|c|c|c|c|c|c|c|c|c|}
\hline LINE & $T E^{M P}$ & PRESS & CONE & ENTHALPY & MASS FLDW & LINE & TEMP & PRESS & CONE & ENTHALPY & MASS FLOW \\
\hline $\begin{array}{r}1 \\
2 \\
3 \\
4 \\
5 \\
6 \\
7 \\
3 \\
9 \\
10 \\
11\end{array}$ & $\begin{array}{l}11000 \\
19029 \\
20522 \\
20922 \\
120.0 \\
158.6 \\
200 \% 8 \\
22020 \\
20522 \\
20592 \\
210 \% 9\end{array}$ & $\begin{array}{r}730 \\
2609 \\
2459 \\
24599 \\
24589 \\
24599 \\
24599 \\
87.6 \\
73.0 \\
109.0 \\
109.0\end{array}$ & $\begin{array}{l}.4715 \\
.4915 \\
04318 \\
.4293 \\
.8667 \\
.5956 \\
04444 \\
01988 \\
.2047 \\
02918 \\
02590\end{array}$ & $\begin{array}{r}-23.5 \\
74.02 \\
83.4 \\
85.8 \\
58.2 \\
93.0 \\
78.0 \\
139.6 \\
120.0 \\
104.4 \\
113.6\end{array}$ & $\begin{array}{r}505556 \\
100000 \\
09267 \\
401620 \\
00228 \\
00389 \\
0947 \\
1.0937 \\
1.5066 \\
0933 \\
09726\end{array}$ & $\begin{array}{l}12 \\
13 \\
14 \\
15 \\
16 \\
17 \\
18 \\
19 \\
20 \\
21 \\
22\end{array}$ & $\begin{array}{l}220.0 \\
209.2 \\
209.2 \\
207.2 \\
207.2 \\
120.0 \\
100.0 \\
158.0 \\
197.2 \\
100.0 \\
196.0\end{array}$ & $\begin{array}{r}109.0 \\
109.0 \\
245.0 \\
245.9 \\
245.9 \\
245.9 \\
73.0 \\
245.9 \\
73.0 \\
73.0 \\
260.9\end{array}$ & $\begin{array}{l}8726 \\
29056 \\
9999 \\
9599 \\
99599 \\
99989 \\
99956 \\
99921 \\
98905 \\
.8905 \\
5069 \\
04915\end{array}$ & $\begin{array}{l}708.5 \\
684.8 \\
641.2 \\
691.2 \\
641.2 \\
89.8 \\
583.3 \\
596.4 \\
696.2 \\
-33.6 \\
74.2\end{array}$ & $\begin{array}{r}.3928 \\
.3935 \\
.0336 \\
.0526 \\
.3936 \\
.4190 \\
.4449 \\
.4408 \\
.0129 \\
.0350 \\
4.5556\end{array}$ \\
\hline
\end{tabular}

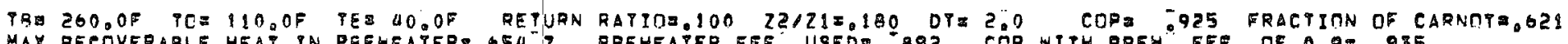

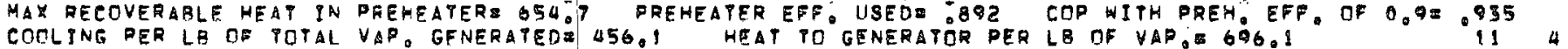

\begin{tabular}{|c|c|c|c|c|c|c|c|c|c|c|c|}
\hline LINE & TEMP & PRE $3 S$ & CONE & ENTHAL.PY & MASS FLUW & LINE & TEMP & PRESS & CONE & ENTARLPY & MASS FLOW \\
\hline $\begin{array}{r}9 \\
2 \\
3 \\
4 \\
5 \\
6 \\
7 \\
9 \\
0 \\
10 \\
11\end{array}$ & $\begin{array}{l}11000 \\
190.9 \\
20506 \\
20800 \\
120.0 \\
159.3 \\
250.0 \\
260.0 \\
206.60 \\
206.06 \\
239.2\end{array}$ & 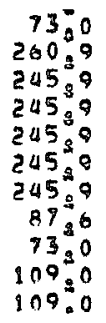 & 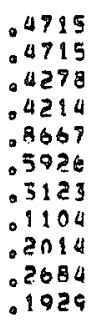 & $\begin{array}{r}-23.5 \\
74.2 \\
85.0 \\
87.4 \\
58.2 \\
019.3 \\
147.4 \\
202.4 \\
122.3 \\
106.6 \\
158.9\end{array}$ & $\begin{array}{r}5.5556 \\
1.0000 \\
09450 \\
4.1306 \\
.0323 \\
.0556 \\
.7535 \\
1.3568 \\
1.5398 \\
.0943 \\
1.0051\end{array}$ & $\begin{array}{l}12 \\
15 \\
14 \\
15 \\
16 \\
18 \\
18 \\
19 \\
20 \\
21 \\
27\end{array}$ & $\begin{array}{l}260.0 \\
208.6 \\
208.6 \\
208.6 \\
208.6 \\
120.0 \\
100.0 \\
159.3 \\
192.0 \\
100.0 \\
196.0\end{array}$ & $\begin{array}{r}209.0 \\
109 \% 0 \\
245.9 \\
245.9 \\
245.9 \\
245.9 \\
73.0 \\
245.9 \\
73.0 \\
73.0 \\
260.9\end{array}$ & $\begin{array}{l}27012 \\
29026 \\
9983 \\
29583 \\
29583 \\
0958 \\
29989 \\
09956 \\
09919 \\
28763 \\
25069 \\
0415\end{array}$ & $\begin{array}{l}799.6 \\
687.8 \\
642.7 \\
642.7 \\
642.7 \\
89.6 \\
583.3 \\
396.0 \\
698.9 \\
-33.6 \\
70.2\end{array}$ & $\begin{array}{r}.4112 \\
.4004 \\
0.0094 \\
.2465 \\
.4253 \\
.5744 \\
.0119 \\
.6067 \\
.1830 \\
0.0505 \\
0.5596\end{array}$ \\
\hline
\end{tabular}


This report was done with support from the Department of Energy. Any conclusions or opinions expressed in this report represent solely those of the author(s) and not necessarily those of The Regents of the University of California, the Lawrence Berkeley Laboratory or the Department of Energy. 
TECHNICAL INFORMATION DEPARTMENT

LAWRENCE BERKELEY LABORATORY

UNIVERSITY OF CALIFORNIA

BERKELEY, CALIFORNIA 94720 